\title{
A 1
}

A SCREENING METHOD FOR FRAGILE X MUTATION: DETECTION OF THE CGG REPEAT IN FMR-1 GENE BY PCR WITH BIOTIN-LABELED PRIMER. - Eiji NANBA, Kousaku OHNO and Kenzo TAKESHITA . Division of Child Neurology, Institute of Neurological Sciences, Tottori University School of Medicine. Yonago

We have developed a new polymerase chain reaction(PCR)-based method for detection of the CGG repeat in FMR-1 gene. No specific product from PCR was detected on the gel with ethidium bromide staining , because 7-deaza-2'-dGTP is necessary for amplification of this repeat. Biotin-labeled primer was used for PCR and the product was transferred to a nylon membrane followed the detection of biotin by Smilight kit. The size of PCR product from normal control were slightly various and around $300 \mathrm{bp}$. No PCR product was detected from 3 fragile $\mathrm{X}$ male patients in 2 families diagnosed by cytogenetic examination. This method is useful for genetic screening of male mental retardation patients to exclude the fragile $\mathrm{X}$ mutation.

A 2

DNA ANALYSIS FOR FRAGILE X SYNDROME

OSami KOSUDA, Utako OGASA, Hideyuki UMII, Ryuji KAWAGLCHI, and Kazumasa HIKIJI

(SRL Inc., Tokyo)

Fragile $X$ syndrome is $X-1$ inked disease having the amplification of (CGG)n repeat sequence in the chromosome $X \mathrm{q} 27.3$.

We performed Southern blot analysis using three probes recognized repetitive sequence resion. Normal controle showed $5.2 \mathrm{~Kb}$ with Eco RI digest and $2.7 \mathrm{~Kb}$ with Eco RI/Bss BII digest as the germ lines by the Southern blot analysis. However, three cell lines established from unrelated the patients with fragile $X$ showed the abnormal bands between 5.2 and $7.7 \mathrm{~Kb}$ with Eco RI digest, and between 2.7 and $7.7 \mathrm{~Kb}$ with Eco RI/Bss HII digest. The suspected 68 samples of fragile X syndrome showed 6 abnormal patterns and 62 normal patterns with Southern blot analysis. The results of Southern blot analysis were agreed with the chromosomal karyotype analysis in $83 \%(5 / 6)$ of the positive patients and $100 \%$ $(62 / 62)$ of the negative patients. 


\section{A 3}

PREPARATION OF DIAGNOSTIC PROBES FOR THE FRAGILE X SYNDROME USING PCR AND MOLECULAR ANALYSES OF AFFECTED FAMILIES. Masatake YAMAUCHI (Div.Genet,, NatI. Inst.Rad.Sci.), Naohiko SEKI (Kazusa DNARes. Inst.), I kuko KONDO (Lab. Hyg., Ehime Univ. Med.), Tadashi KAdII (Dept.Ped., Yamaguchi Univ.Med.) and Tada-aki HORI (Div.Genet,, Nat I. Inst. Rad. Sci.)

Fragile $X$ syndrome is one of the most common birth defects $(1 / 1500-$ 2000) next to Down syndrome, and is associated both with mental retardation and with specific expression of a chromosomal fragile site at Xq27.3 (FRAXA). Recently Xq27.3 region has been cloned and the mutation causing fragile $X$ syndrome has been uncovered at molecular level. We prepared the diagnostic DNA probes by direct enzymatic amplification of human chromosomal DNA. The probe was applied for the analyses of fragile $X$ families on Southern blot. Two types of the fragile $X$ mutation, premutation in normal transmitters and full-mutation in patients, were detected. The inheritances of the mutation in several families were also analysed. The mutations in female carriers who have mild mental retardation were confirmed not to be the premutation but the full-mutation which were the same as the patients'.

\section{A 4}

DYNAMIC MUTATION ASSOCIATED WITH FRAGLE X SYNDROME AND DNA METHYLATION Tada-aki HORI, Masatake YAMAUCHI, Naohiko SEKI (Div. Genet., Natl, Inst. Radiol. Sci., Chiba), Tadashi KAJI (Dept. Pediatr., Yamaguchi Univ. School Med., Ube) and Ikuko KONDO (Lab. Hygien., Ehime Univ. School Med.)

The fragile $\mathrm{X}$ syndrome has recently been characterized as a dynamic mutations due to heritable unstable DNAsequence, $p(C C G) n$ repeat, in the FRAXA locus. A correlation between fragile X-genotypes and hypermethylation of an adjacent $\mathrm{CpG}$ island was examined. We showed that the $\mathrm{p}(\mathrm{CCG}) \mathrm{n}$ repeat in the fragile $\mathrm{X}$ chromosome usually increased in size when transmitted by female and the degree of methylation in the $\mathrm{CpG}$ island correlated with the increased sizes of the $\mathrm{p}(\mathrm{CCG}) \mathrm{n}$ repeats. When hypermethylated full mutation was transmitted by a male to his daughters, both the size of the p(CCG)n repeat and the degree of methylation reduced to the premutation range. Our observations suggest that female meiosis has a greater potential for amplifing unstable DNA sequences and can transmitted them though germ cells, while male germ cells can not tolerate highly amplified unstable DNA sequences. In addition, individuals with full mutation exhibited somatic variation both in copy numbers an methylation patterns due to increased instability in their culture lymphoblasts. 
A 5

THE METHYLATION STUDY ON THE CPG ISLAND OF THE FRAGILE X GENE. Taku IHDA, Yulaka NAKAHORI, Karo TANAKA, Yasuo NAKAGOME (Dept. Hum. Genet., Tokyo Univ., Tokyo), Ikuko KONDO (Dept. Hygiene., Ehime Univ., Matsuyama), Tadashi KAJII (Dept. Pediatr., Yamaguchi Univ, Ube) Tadao ARINAMI (Dept. Clin. Genet., Tsukuba Univ., Ibaragi) Kouji NARAHARA (Dept. Pediatr., Okayama Univ, Okayama) Tomoko HASEGAWA (Shizuoka Children's Hosp, Shizuoka)

Previously, we studied Japanese families segregating for the fragile $X$ syndrome and showed the amplification of the (CGG)n repeat sequence adjacent to the CpG island in the FMR-1 gene. We demonstrated that most of the fragile $\mathrm{X}$ positive, mentally retarded males show a characteristic smear of fragments corresponding to amplification. There were some patients with no amplification although they were clinically diagnosed as fragile $\mathrm{X}$ syndrome. To access this problem, we have analyzed the methylation status of the CpG island. We have found that the amplification of the (CGG)n repeat is always co-relate with the methylation of the CpG island. Therefore, the patients with no amplification or no methylation may be classified as the different disease from the molecular standpoint. The $\mathrm{CpG}$ island is usually methylated on the inactive $\mathrm{X}$ chromosome. The study on the DNA samples of normal male and female placenta, however, revealed that the $\mathrm{CpG}$ island escapes the methylation in the case of placenta even it is on the inactive $\mathrm{X}$ chromosome.

A 6

DNA DIAGNOSIS OF MYOTONIC DYSTROPHY.

Naoki YAMANAKA, Hidehisa YAMAGATA, Tetsuro MIKI and Toshio OGIHARA

(Dept.Geriat.Med., Osaka Uni. Med.Sch.,Osaka)

Recently the myotonic dystrophy(MyD) gene was cloned and its sequence determined. The mutation was identified as the expansion of a tri nucleotide (CTC) a repeat located in the $3^{\prime}$ untranslated region of a gene whose predicted product is a member of the protein kinase fami1y. An allelic expansion is detectable as a gene insetion by Southern blot analysis using cDNA probe. The number of a (CTG) n repeat is determinable by FCR amplification. We analyzed DNA from 74 patients, 54 normal individuals and 7 so-called sporadic cases. An increased (CTG) a repeat length was demonstrable in the majority of MyD patients (91\%) by Southern blot analysis of EcoRI digested genomic DNA probed with cDNA25. All the rest $(9 \% ; 7$ cases) was clinically mild. In the ambiguous cases Southern blot with Pval and Bgll was useful for accurate diagnosis. PCR amplification alone had a limited use as an informative diagnostic test. We conclude that a combination of Southern blot and PCR is a direct and accurate diagnosis. 
A 7

ANALYSIS OF HERITABLE UNSTABLE DNA SEQUENCES IN JAPANESE MYOTONIC DYSTROPHY. Hidehisa YAMAGATA, Naoki YAMANAKA, Tetsuro MIKI and Toshio OGIHARA (Dept.Geriat.Med.,Osaka Univ.Med.Sch.,Osaka)

The myotonic dystrophy (HyD) mutation has recently been identified as an unstable trinucleotide (CTG) n repeat which is present 5-30 times in the normal population but which is amplified 50-2000 times in MyD. We have analyzed this heritable unstable DNA region in about 200 Japanese myotonic dystrophy family members. PCR was carried out to determine the copy number of the (CTG) n repeat. Using data from unrelated individuals, 13 copies of the CTG repeat were most commonly seen in the japanese populations. The distribution of allele frequencies of $(\mathrm{CTG}) \mathrm{n}$ repeats was statistically different in the Japanese and Caucasian populations. In this study, normal apper 1 imit was 35 copies of the repeat, which is larger than reported so far. The repeat length correlated with severity of the disease and age at onset. There was a linkage disequilibrium between (CTG) repeat number $(j \& 12,13)$ and the nearest DNA marker $(p 37.1)$. This suggests that expansion from 5 to $12 \& 13$ occured in the past.

\section{A 8}

THE ORNITHINE AMINOTRANSFERASE GENE MUTATIONS IN JAPANESE GYRATE ATROPHY PATIENTS. Yukihiko MASHIMA (Dept. of Oph thalmol., Keio Univ., Tokyo), Takashi SHINO, Makoto TAMAI (Dept. of Ophthalmo1., Tohoku Univ., Sendai) and George INANA (Bascom Palmer Eye Institute, Univ, of Miami, Miami)

Gyrate atrophy(GA) is an autosomal recessive chorioretinal degenetation of the eye caused by deficiency of ornithine aminotransferase(OAT). Using a combination of PCR, DGGE and direct sequencing, we identified eight different mutations in the OAT gene in seven unrelated Japanese GA patients. Case 1(one letter symbol for the original and mutated amino acid and the codon position):E125 N326K; Case 2:H319Y (Homozygote); Case 3:G142E (Homozygote); Case 4: T181M(Homozygote); Case 5:R426ter(Homozygote); Case 6:D195Y, R271K; Case $7: R 271 \mathrm{~K}$ (Homozygote). Case 2, 4, 6 show consanguinity. These mutations at the OAT locus have not been identified in another ethnic groups . 
A 9

GENETIC ANALYSIS OF HYPERTROPHIC CARDIOMYOPATHY Akinori KIMURA $^{1)}$, Hirofumi NISHI ${ }^{1) 2}$, Haruhito HARADA ${ }^{1) 2}$, Yoshinori KOGA ${ }^{2}$, Hironori TOSHIMA ${ }^{2)}$, and Takehiko SASAZUKI ${ }^{1)}$ 1)Dept. Genet., Med. Inst. Bioreg., Kyushu Univ., Fukuoka and 2)Third Dept. Int. Med., Kurume Univ., Kurume

Mutations in cardiac $\beta$ myosin heavy chain gene ( $\beta \mathrm{MHC}$ ) on the chromosome 14 were reported in some Caucasian families with hypertrophic cardiomyopathy (HCM). Several other Caucasian families however showed no linkage with $\beta M H C$, suggesting another genetic defect or disease heterogeniety in HCM. To decipher the genetic defect in the Japanese HCM, we performed linkage studies in 28 multiplex families, in which 73 affected and 55 unaffected members were analyzed. The analysis of two polymorphic dinucleotide repeats in the $\beta \mathrm{MHC}$ gene ( $5^{\prime} \mathrm{UT}$ and intron 24) demonstrated that there were 5 families showing lod scores of less than -2.0 at $\theta=0.001$ (penetrance at $80 \%$ ) and that the combined lod score at $\theta=0.00$ was 1.82 in the other 23 families. Although we could not confirm the linkage between HCM and $\beta$ MHC in the Japanese population, the $\beta M H C$ gene was analyzed by single-stranded conformation polymorphism analysis in 108 unrelated Japanese patients. By the analysis of putative functionally important exons (exon $3-20$, and 23), we found 3 one base substitutions in the $\beta M H C$ gene from 4 patients at exon 16,20, and 23. These observations suggest that the mutations in $\beta M H C$ gene may cause HCM in a few cases but the other Japanese HCM have a genetic defect in other locus than the $\beta \mathrm{MHC}$. A DNA marker, PALB, that showed a combined maximum lod score of 3.77 at $\theta=0.00$ and another DNA marker, M2, showing maximum lod score of 1.74 at $\theta=0.11$ suggest the other HCM locus on the chromosome $18 \mathrm{q}$.

\section{A 10}

DELETION SCREENING OF DYSTROPHIN GENE IN JAPANESE PATIENTS WITH VARIOUS TYPES OF MUSCULAR DYSTROPHY BY MULTIPLEX DNA AMPLIFICATION. Eiji SADA,Takahiko SHIOSAKA (Dept.Labo.Sci.Ehime College of Med.Sci.,Ehime), Minoru HAMADA, Hitoshi TAKENAKA, Hideharu MARUYAMA (Dept.Hyg.,Miyazaki Med.College,Miyazaki), Tuyoshi NAKACHI, Kenjiro INOUE (Dept.Med.\&Pediatr., Miyazaki Higashi Hosp., Miyazaki), Michihiro SUMIDA (Dept. Biochem. Ehime Univ.,Ehime), Shigeru FUIITA (The 1st Dept.Med.Ehime Univ.,Ehime).

Thirty-Six Japanese patients with various types of muscular dystrophy were investigated for deletion of the dystrophin gene in comparison with normal control using the multiplex polymerase chain reaction method. Six exonic region were analyzed. Thirteen patients with Duchenne-type muscular dystrophy(DMD), 11 limb-girdle-type muscular dystrophy(LG), 6 with Fukuyama-type muscular congenital muscular dystrophy(FCMD), 2 with facioscapulohumeral-type muscular dystrophy(FSH), 2 with myotonic dystrophy(MMD) and 2 with undifined-type muscular dystrophy were examined. Dystrophin gene deletion were detected in $61.5 \%$ of DMD, $27.3 \%$ of $\mathrm{LG}$ and $33.3 \%$ of FCMD patients mainly on the central portion (Exon 45,51), but were not detected in FSH and MMD patients.

This method was shown to be a useful laboratory screening techniqe applicable to muscular dystrophy patients. Although the reason for the deletion in LG and FCMD patients are not clear, such relationship is likely suspected between the dystrophin gene and those types of this disease, further investigation are required to clarify the sequence of the deleted region to the direct pathogenesis. 


\section{A 11}

DELETION DETECTION OF DUCHENNE MUSCULAR DYSTROPHY IN THE JAPANESE POPULATION

- COMPARATIVE STUDIES WITH POLYMERASE CHAIN REACTION AND SOUTHERN BLOT ANALYSISSusumu KATAYAMA, Naoki TAKESHITA, Tomone YANO, Tsuneyuki UBAGAI, Qiu Xiao JIN. Harumi KUBO and Kazuo MOMOSE

(The First Dept. Obstet. Gynecol., School of Medicine, Toho University, Tokyo )

We examined and compared the efficasy of multiplex PCR and CDNA analysis for the detection of deletions of DMD in the Japanese population. Thirty males with DMD from 27 Japanese families were studied to detect deletions with multiplex PCR. Twenty four of these males with DMD were also investigated with Southern blot analysis to compare the rate of detection for deletion. Out of 27 families 14 families had only one sporadic male with DMD in their pedigree, and 13 families had at least two males affected with DMD. We used a total of five dystrophin cDNA probes for deletion detection i.e. $1-2 a, 2 b-3,4-5 a, 5 b-7$ and 8 from 5 end of the DMD gene for Southern analysis. A total of 19 regions were amplified to detect deletions, 10 regions (Exon 4, 8, 12,17, 19, 44, 45, 48, 51) by Chamberlain et al. and another 9 regions (mucle-specific promoter, Exon $3,6,13,43,47,49,50,52,60$ ) by Beggs et al. Deletions were detected in 16 out of 30 indivisuals with DMD (53\%) with a total of 19 regions amplified by PCR. Southern analysis detected deletions in 17 out of 24 with DMD $(71$ \%) with a total of five cDNA probes. Fourteen out of 17 deletions ( $82 \%$ ) those detected with cDNA probes were also confirmed with multiplex PCR. Multiplex PCR anlysis could be an efficient, useful alternative to the conventional Southern analysis to detect deletions for postnatal and prenatal diagnosis of DMD in the Japanese population .

\section{A 12}

DETECTION OF DMD CARRIERS WITH DELETIONS OR DUPLICATIONS : APPLICATION OF QUANTITATION OF GENE DOSAGE BY USING COMBINED PCR AND HPLC

Jun-ichi ASAKAWA, Chiyoko SATOH, Mieko KODAIRA, Keiko HIYAMA, Kiyotaka FUKUDA, Hitoshi KAMEO (Dept. of Genetics, Radiation Effects Research Foundation, Hiroshima) and Takenori KARAKAWA(National Sanatorium, Hara Hospital)

We have developed a technique to detect accurately heterozygous carriers of a deletion or a duplication. Specific target sequences were amplified by the polymerase chain reaction (PCR) and the products were subsequently analyzed by highperformance liquid chromatography (HPLC). Examples from four loci demonstrated that 24-27 cycles of amplification for a single copy DNA, based on 50 ng genomic DNA results in excellent quantitation which readily permits the detection of heterozygous carriers of a deletion. We have demonstrated that triplex PCR (three targets in a single PCR) entails no loss of precision. We have applied this method to the detection of DMD carriers. This method could accurately differentiate the heterozygous carriers of a deletion or a duplication from normals in 10 family studies, 9 for deletion-type DMD patients and one for a duplication-type DMD patient. 


\section{A 13}

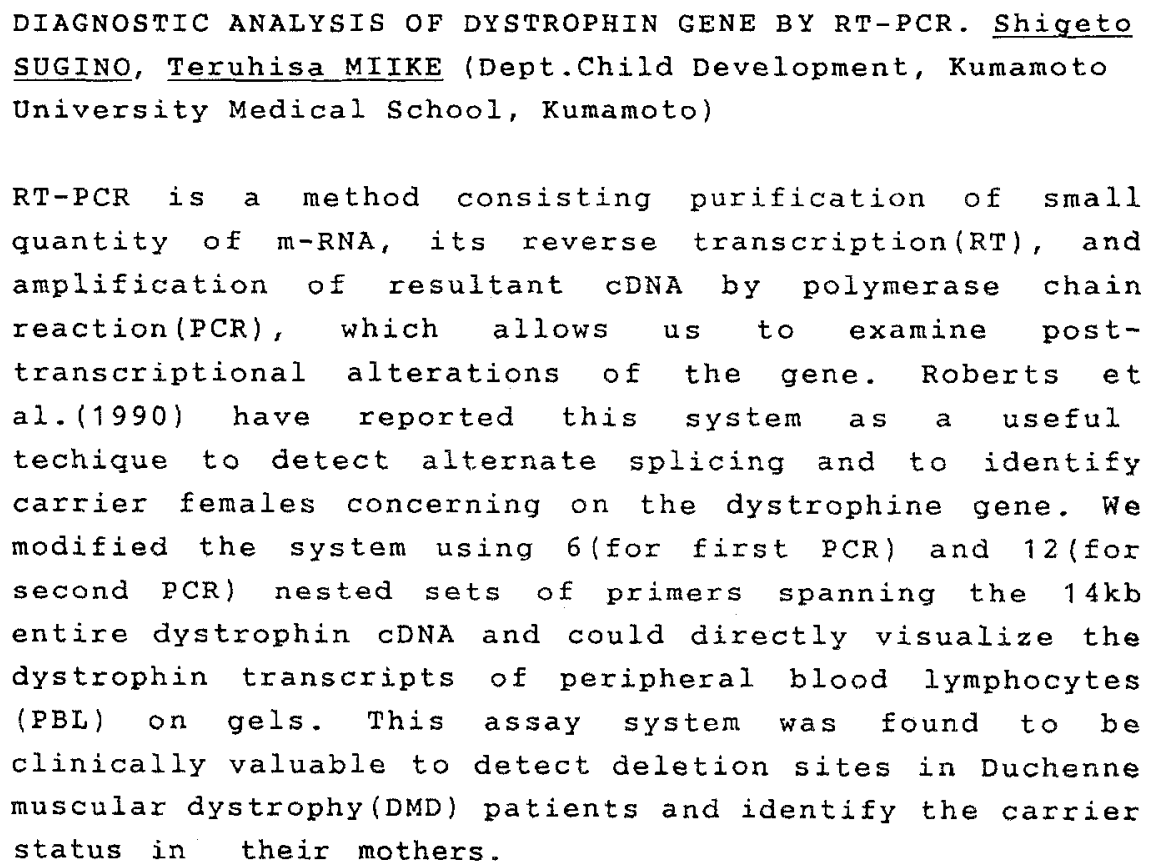

\section{A 14}

PRENATAL DIAGNOSIS OF A DUCHENNE MUSCULAR DYSTROPHY FAMILY USING POLYMERASE CHAIN REACTION AMPLIFICATION. Kayoko SAITO, Takayo HARADA, Akemi YAMAUCHI, Kiyoko IKEYA, Reiko MORITA, Izumi SAKUMA, Yukio FUKUYAMA (Dept. Pediatr., Tokyo Women's Medical College, Tokyo)

Molecular genetic analysis was conducted on a conceptus from a woman who had given birth to two sons with Duchenne muscular dystrophy (DMD) and was known to be a carrier of an aberrant DMD gene. A genomic deletion of exons 49-52 was demonstrated in the elder son and the same type of deletion was found in a younger brother 8 months of age who was still symptom-free, as well as in the mother. At 16 weeks gestational age in her fourth pregnancy, DNA was extracted from amniotic fluid cells. Female sex was established in the fetus by means of amplification of sequences specific for the $\mathrm{Y}$ chromosome. The fetus may be a carrier, because the intensity of PCR products from exon 51 (the deleted exon) was half that from exon 48 (the intact exon). We obtained the above results at 18 weeks gestational age and confirmed fetal sex at 19 weeks by karyotype analysis. Thus, PCR amplification permitted rapid prenatal diagnosis. We also utilized prenatal diagnosis protocol for DMD families based on molecular genetic analysis. 
A 15

PRENATAL DYAGNOSIS OF DUCHENNE AND BECKER MUSCULAR DYSTROPHY BY DELETION AND LINKAGE ANALYSIS USING POLYMERASE CHAIN REACTION METHODS. HirokO TSUKAMOTO, Takahiro SUGITA (Dept. Pediatr., Momoyama Hospital, Osaka) Hisao FUKUSHIMA, Koji INUI and Shintaro OKADA (Dept. Pediatr., Osaka Univ., Osaka)

Prenatal diagnosis in four cases of Duchenne and one Becker muscular dystrophy families were performed by deletion analysis and linkage analysis of 7 polymorphic sites (pERT87 and CA polymorphisms at $5^{\prime}$ and $3^{\prime}$ reagions of the dystrophin gene) using polymerase chain reaction (PCR) methods. The sex of each case was also determined using cultured amniotic cells. In five cases, two male cases, whose probands showed the deletion, were diagnosed as normal males because they did't show the deletion. In one male case, whose proband had no deletion of the dystrophin gene, the diagnosis was impossible because the polymorphic patterns of the proband, the second normal brother and the male case completely matched with one of their mother's patterns. The other male case was diagnosed as DMD because his polymorphic pattern matched with the proband's pattern and one of their mother's patterns. One female case of DMD family was diagnosed as non-carrier because her both polymorphic patterns were different from the proband's pattern. As above, prenatal diagnosis of DMD and BMD families by linkage analysis using PCR methods is simple and very useful except for the cases suspected of gonadal mosaicism or new mutation.

\section{A 16}

A CASE OF DUCHENNE MUSCULAR DYSTROPHY WITH NORMAL INTELLIGENCE IN SPITE OF GENOMIC DELETION OF BOTH MUSCLE AND BRAIN PROMOTORS.

Izumi SAKUMA, Kayoko SAITO, Akemi YAMAUCHI, Kiyoko IKEYA, Reiko MORITA, Maki I MANO, Makiko OSAWA, Yukio FUKUYAMA

(Dept. of Pediatr., Tokyo Women's Medical College, Tokyo)

We report a Duchenne muscular dystrophy(DMD) patient with normal mentality who had deletions of brain and muscle promotors as well as of exons 2 through 7 of the dystrophin gene.

[Case] The patient, a 21 year old male, had no family history of DMD. Wechsler adult intelligence scale revealed a normal verbal IQ (97) at the age of 21 . He has a third grade license from the Society for testing English proficiency Inc.

[Method] High molecular weight DNA was prepared from peripheral lymphocytes. Dystrophin gene including brain and muscle promoter was examined.

[Result] A dystrophin gene deletion, encompassing brain and muscle promotors as well as exons 2 through 7 was detected.

[Discussion] Lack of brain type dystrophin has been considered to cause mental retardation, of ten seen in DMD patients. This is the first report of a brain promotor deletion in a patient with normal mentality and should prompt reconsideration of the above hypothesis. 
A 17

POSSIBLE DEFFERENT MUTATION RATE BETWEEN MALES AND FEMALES IN DUCHENNE MUSCULAR DYSTROPHY WITH REARRANGEMENTS OF THE DYSTROPHIN GENE. Natsuki IMOTO ${ }^{1}$, Tadao ARINAMI ${ }^{2}$, Mitsuru KAWAI ${ }^{3}$, Kiichiro MATSUMURA ${ }^{3}$, Hiroki YAMADA ${ }^{3}$, Kenzo HAMANO $^{1}$, Hitoshi TAKITA ${ }^{1}$, and Hideo HAMAGUCHI ${ }^{2}$, ( ${ }^{1}$ Dept. Pediatr., ${ }^{3}$ Dept. Med. Genet., Univ. Tsukuba, Tsukuba, ${ }^{2}$ Dept. Neurol., Shimoshizu Natl. Hosp., Yotsukaido)

In the case of the same mutation rate between males and females, one third of the patients are due to new mutations in germ cells of their mothers in X-linked recessive hereditary diseases with zero biological fitness. Rearrangements in the dystrophin gene have been found in about two thirds of Duchenne muscular dystrophy (DMD) patients. In this study we tried to answer the question whether the mutation rate for DMD rearrangements is equal between males and females. We determined carrier status of 20 mothers whose sons were sporadic DMD with dystrophin gene rearrangements, and compared the observed carrier ratio with the theoretical ratio. Southern blot analysis revealed that 18 of the 20 mothers $(90 \%)$ were DMD carrier. The observed ratio was significantly higher than the theoretical carrier ratio of $2 / 3$ $(67 \%)\left(\chi^{2}=4.8, P<0.03\right)$. This result suggests that the mutation rate for dystrophin gene rearrangements is higher in males than in females.

\section{A 18}

CLINICAL FEATURES IN A JAPANESE CASE OF AUTOSOMAL DOMINANT RETINITIS PIGMENTOSA WITH RHODOPSIN GENE CODON 17 MUTATION. Mutsuko HAYAKAWA, Yoshihiro HOTTA, Yoshie IMAI, Keiko FUJIKI, Atsuo NAKAMURA, Atsushi KANAI (Dept. of Ophthalmol., Juntendo Univ., Tokyo) and Kenji YANASHIMA (Dept. of Ophthalmol., National Rehabilitation Center for the Disabled, Saitama)

Retinitis pigmentosa shows genetic heterogeneity and phenotypic variation even within the same inheritance pattern. Several rhodopsin mutations have been reported in autosomal dominant retinitis pigmentosa (ADRP) and their relation to clinical features has been investigated. In Japan, only three mutations, in codons 347, 17 and 181, have been reported. We report here the clinical features of a 49 y.o. male with a codon 17 mutation, threonine-to-methionine change (Thr-17-Met), in the rhodopsin gene. He first noticed decreased visual acuity at age 38 , night blindness and narrowed visual field at 40 . He has pigmentary degeneration mainly in the inferior fundus, severe upper visual field loss and preserved rod and cone functions on electroretinography. Findings almost the same as Caucasian Thr-17 - Met cases indicate phenotypic similarities with the same mutation despite different racial background. His clinical features differ from those of codon 347 and 181 mutations, i.e. molecular genetic heterogeneity reflects phenotypic variation in ADRP. 


\section{A 19}

STUDY OF RHODOPSIN MUTATIONS IN AUTOSOMAL DOMINANT RETINITIS PIGMENTOSA (ADRP). Keiko FUJIKI, Yoshihiro HOTTA, Mutsuko HAYAKAWA, Hitoshi SAKUMA, Misako TAKEDA, Atsushi KANAI (Dept. Ophthalmol., Juntendo Univ., Tokyo) and George INANA (Bascom Palmer Eye Inst., Univ. of Miami, Miami)

We have analyzed Japanese patients with ADRP and detected two mutations of Pro-347-Leu and Thr-17-Met in two families. In the present study, the DNA fragments for each exon were amplified by means of PCR (polymerase chain reaction) for 13 unrelated patients, and were tested by SSCP (single strand conformation polymorphism) and DGGE (denaturing gradient gel electrophoresis) methods. We did not detect any new mutation in the parts of exons. The mutations of rhodopsin gene in Japanese ADRP patients seem to be infrequent compared with that (30\%) of USA. Polymorphisms of single nucleotide substitution of $\mathrm{A}-269-\mathrm{G}$ in the 5 ' noncoding region and $\mathrm{G}-4145-\mathrm{A}$ in the 4 th intron were represented. The former was $35 \%(4 / 13)$ heterozygotes of $\mathrm{A} / \mathrm{G}$ and $46 \%(6 / 13)$ homozygotes of $\mathrm{G} / \mathrm{G}$, and the latter was $46 \%(6 / 13)$ heterozygotes of $\mathrm{G} / \mathrm{A}$. These values are higher than that in USA. A patient of heterozygote $(\mathrm{C} / \mathrm{A})$ on $\mathrm{C}-5321-\mathrm{A}$ substitution in the $3^{\prime}$ noncoding region was also detected.

\section{A 20}

RHODOPSIN GENE ANALYSIS IN AUTOSOMAL DOMINANT RETINITIS PIGMENTOSA(ADRP) PATIENTS. Masamichi SAGA, Yukihiko MASHIMA, Yoshihisa OGUCHI(Dept. Ophthalmol., Keio Univ. Sch. Med., Tokyo), Jun KUDOH and Nobuyoshi SHIMLZU (Dept: Mol. Biol., Keio Univ. Sch. Med., Tokyo)

We analyzed the rhodopsin gene in 16 Japanese patients with ADRP using the polymerase chain reaction(PCR) followed by restriction enzyme digestion. The possible mutations checked by this strategy were point mutations at codons 23 (Pro-Leu), 51, 89, 125, 135, 167, 178, 181, 182, $190,267,344,347$, and deletion mutations at codons $68-71$.

We found an RFLP within codon 181 and/or 182 in one patient. It was identified as a G-A substitution in the first base of codon 181 replacing Glu with Lys. This patient showed the onset of ADRP with a diffuse loss of rod function in childhood but preserved a relatively good cone function, and thus she was diagnosed as the type I category of ADRP. 


\section{A 21}

AN ATYPICAL CASE OF LEBER'S HEREDITARY OPTIC NEUROPATHY WITH WALLACE'S MUTATION. Yoshihiro HOTTA, Mutsuko HAYAKAWA, Keiko FUJIKI, Koutaro SHINOHARA, Misako TAKEDA, Atsushi KANAI (Dept. Ophthalmol., Juntendo Univ., Tokyo), Kenji YANASHIMA, (Dept. Ophthalmol., National Rehabilitation Center, Tokorozawa) and Hiroshi KANEKO (Dept. Ophthalmol., Matsudo City Hospital., Matsudo)

The association of $\mathrm{G}$ to $\mathrm{A}$ transition mutation of nucleotide position ( $\mathrm{nt}$ ) 11778 of mitochondrial DNA (mtDNA), the so - called Wallace's mutation, with Leber's hereditary optic neuropathy (LHON) was reported. Since the Wallace's mutation was frequently observed (approximately 90\%) in Japanese LHON pedigrees, the detection of the mutation is useful for the diagnosis. We report an atypical case of LHON with Wallace's mutation. A 32 -year - old male complained of right visual loss. We followed him up with medications for more than 2 years. Although his right visual acuity recovered, his left visual acuity decreased. No remarkable clinical findings were detected in his mother. Nt 11778 of mtDNA of leukocyte was analyzed using restriction enzymes $\underline{\text { Sfa }}$ NI and Mae III and slot blot hybridization in the patient, his father and mother. Slot blot hybridization showed that the patient has $100 \%$ mutant mtDNA, his father has $100 \%$ wild mtDNA, and his mother has $49.7 \%$ wild and $50.3 \%$ mutant mtDNA.

\section{A 22}

ANALYSIS OF MITOCHONDRIAL DNA POLYMORPHISM OF LEBER'S HEREDITARY OPTIC NEUROPATHY

Yoshiki HIIDA, Yukihiko MASHIMA, Yoshihisa OGUCHI, Jun KUDOH ${ }^{*}$, Nobuyoshi SHIMIZU*

(Dept. Ophthalmol. and Mol. Biol. ${ }^{*}$, Keio Univ. Sch. Med., Tokyo)

Leber's hereditary optic neuropathy (LHON) is characterized by bilateral optic neuropathy that causes severe loss of central vision. Recently, the association between maternally inherited LHON and the G-to-A substitution of mitochondrial DNA (mtDNA) at nucleotide position (nt) 11778 has been confirmed. To find the genetic background of LHON with nt1 1778 mutation, mtDNA polymorphisms of twenty Japanese LHON pedigrees were examined. Specific regions of NADH dehydrogenase subunit genes were amplified by polymerase chain reaction (PCR) with three pairs of synthetic oligonucleotide primers. These PCR products were digested with eight restriction endonucleases (Alul, Avall, Haell, Hhal, Hinfl, Hpall, Rsal, Taql) and restriction fragment length polymorphisms (RFLPS) were analyzed. Six types of RFLPS were detected in twenty Japanese LHON pedigrees, and thus these pedigrees could be divided into seven groups. These results illustrated the polymorphic nature of mtDNA in Japanese LHON pedigrees. 


\title{
A 23
}

MITOCHONDRIAL MYOPATHY INHERITED AS AUTOSOMAL DOMINANT TRAIT - REPORT OF A CASE AND REVIEW OF LITERATURES. Hisaomi KAWAI, Masashi AKAIKE, Kenji YOKOI, Yoshihiko NISHIDA, Yasutami TAMAKI, Kenjiro MASUDA, Haruhito NAKAHIRA and Shiro SAITO (First Dept. of Int. Med., School of Med., The Univ. of Tokushima, Tokushima)

We report a kindred of mitochondrial myopathy which appeared to be transmitted as an autosomal dominant trait. The proband is a 58-year-old Japanese male who presented blepharoptosis, external ophthalmoplegia, dysphagia and muscle atrophies of upper extremities and shoulder-girdles. Serum lactate level was elevated. Muscle biopsy revealed a high percentage $(7 \%)$ of ragged red fibers. Analysis of muscle mitochondrial DNA demonstrated multiple large scale deletions. Six family members including his father and two children had similar symptoms. Five kindreds with autosomal dominantly inherited mitochondrial myopathy with deletions in mitochondrial DNA (mtDNA) have been previously reported. Large scale deletions, ranging in size from 4.2 to $6.0 \mathrm{~kb}$, were found all in the non-D-loop region. Autosomal dominant inheritance in these cases may indicate the influence of nuclear DNA on replication of mtDNA.

\section{A 24}

\author{
A STUDY OF MUTATION(S) AT EXON 17 OF AMYLOID PRECURSOR GENE IN \\ ALZHEIMER'S DISEASE, SCHIZOPHRENIA AND PARKINSON'S DISEASE. \\ Shin NANKO, Mineko HATTORI, Tsukasa SASAKI, Hajime KAZAMATSURI \\ (Dept. of Psychiatry, Teikyo Univ. Sch. of Med.) Kuniaki TANAKA, Kunihiro ISSE \\ (Dept. of Psychiatry, Tokyo Metropolitan Tama Geriatric Hospital) Makoto. \\ UCHIYAMA (NIMH, NCNP) Shoji KUWATA, Takeo IUII (Dept. of Transfusion Med. \\ Univ. of Tokyo)
}

Since the report of missense mutation of hereditary cerebral hemorthage, Dutch type at 693 codon (Levy et al. 1990), there have been a number of reports of mutation(s) on exons 16 and 17 of amyloid precursor (APP) gene in neuro-psychiatric diseases including Alzheimer's disease at codon 717 (Goate et al. 1991) or schizophrenia at codon 713 (Jones et al. 1992). We have investigated possible mutations of exon 17 of patients with several neuro-psychiatric diseases. Genomic DNA was extracted from whole blood sample of the patients. Exon 17 of APP gene was amplified by PCR method. We have examined the whole sequence of exon 17 using DNA sequencer (Applied Biosystem 373A) in six patients with early onset Alzheimer's disease; two of them were siblings. We also examined the missense mutations at codons 717 and 713 by searching $B c l$ I and MaeIII restriction sites respectively in 7 patients with sporadic early onset Alzheimer's disease, 30 patients with schizophrenia and 6 patients with early onset Parkinson's disease. No mutation was found for these regions or sites examined among these patients. These results indicate that the mufations on these codons and exon are rare among these disorders. (We thank Prof. Shoji Tsuji and Dr. Satoru Naruse at Niigata Univ. for providing DNA sample of patient with mutation at codon 717.) 


\section{A 25}

A POINT MUTATION OF THE AMYLOID PRECURSOR PROTEIN GENE IN SPORADIC ALZHEIMER' S DISEASE. Yasuhi ro NONOMURA, Hi roshi YONEDA, Toru ISHIDA, Yasuhi ro INAYAMA, Yoshihi ro KONO, Toshiaki SAKAI Dept. Neuropsychiatry, Osaka Med. Col1. Takatsuki, Osaka

A point mutation at exon 17 in the amyloid precursor protein (APP) gene causes an amino-acid substitution ( $\mathrm{Val}-\mathrm{Ile}$ ) and a BCL-1 recognition site. We investigated this mutation in 50 sporadic Alzheimer's disease ( $A D$ ) cases and 180 normal individuals by PCR (polymerase chain reaction) method. We extracted DNA from blood samples and amplified the exon 17 of the APP gene by PCR. PCR products were digested by $\mathrm{BCL}-1$. BCL-1 digests were electrophoresed in $3 \%$ agarose gel and stained with ethidium bromide.

Fifty sporadic AD cases and 180 normal individuals did not show a point mutation at exan 17 of the APP gene. This result suggests that sporadic cases of $A D$ are not caused by this point mutation.

\section{A 26}

SCREENING OF THE MISSENSE MUTATION PRODUCING THE ${ }^{717} \mathrm{Val} \rightarrow$ Ile SUBSTITUTION IN THE AMYLOID PRECURSOR PROTEIN IN JAPANESE FAMILIAL AND SPORADIC ALZHEIMER'S DISEASE. Toshihiro YOSHIZAWA ${ }^{1}$, Hidehiro MIZASAWA ${ }^{1}$, Yasuko KOMATSUZAKI ${ }^{2}$, Hiroyuki IWAMOTO ${ }^{2}$, Michiyo KARASAKI $^{2}$ ('Dept. Neurol., Inst. Clin. Med., Univ. Tsukuba, Tsukuba; ${ }^{1}$ Dept. Geriatr. Med., Hatsuishi Hosp., Kashiwa.)

We investigated the missense mutation producing the ${ }^{717} \mathrm{Val} \rightarrow$ Ile substitution in the amyloid precursor protein in 41 Japanese cases of early-onset familial Alzheimer's disease (FAD), late-onset FAD and sporadic Alzheimer's disease (AD) by polymerase chain reaction and restriction enzyme polymorphism by $B c l l$. Among 9 early-onset FAD patients derived from independent families, only one had the missense mutation. Neither 5 patients with late-onset FAD nor 27 patients with sporadic AD had the mutation. Our data suggest that this type of mutation may not be a common cause of Japanese early-onset FAD. Moreover, this mutation could be absent in late-onset FAD and sporadic AD in Japan. 
GENETIC HETEROGENEITY OF EARLY-ONSET TYPE OF FAMILIAL ALZHEIMER'S DISEASE (FAD) REVEALED BY LINKAGE ANALYSIS WITH D21S210 CLOSE TO A4/ $\beta$ AMYLOID PROTEIN PRECURSOR (APP) GENE

Kouzin KAMINO, Tetsuro MIKI, Toshio OGIHARA (Dept. Geriat.Med.,Osaka Univ. Med. Sch.,Osaka), George M. Martin (Dept.Path., U niv.of Washington, Washington, USA), Thomas D.Bird and Gerard D.Schellenberg (Div.Neuro., Dept.Med., Univ. of Washington, Washington ,USA)

Ten families of FAD in USA have ancestors at the same two villages in Russia, and are called as Volga-German families. FAD of these families represented mean age of onset at 55.9 years and mean duration of 10 years. Linkage analysis using D21S210, located close to APP gene in chromosome 21 , revealed $\mathrm{Z}=-15.12(\theta=0.001)$ with AD of 7 Volga-German families. Direct sequensing of exon 16 and exon 17 of APP gene proved no mutation in these families. It was proved that APP gene is excluded from causative gene of FAD of Volga German families, and that genetic heterogeneity of FAD with an early age of onset exists. Osaka- 1 family shows FAD with mean age of onset at 48.5 years, and has been revealed point mutation at codon 717 (Val $\rightarrow$ Ile) of APP gene in the affected. Genetic heterogeneity could reflect phenotype of FAD.

\section{A 28}

MOLECULAR ANALYSIS OF HUMAN ERYTHROCYTE SPECIFIC AMP DEAMINASE DEFICIENCY. Yasukazu YAMADA, Haruko GOTO, and Nobuaki OGASAWARA (Dept. Genet., Inst. Developmental Res., Aichi Pref. Colony, Kasugai, Aichi)

Erythrocyte specific AMP deaminase deficiency identified firstly by us, is clinically completely asymptomatic, whereas muscle specific AMP deaminase deficiency was discovered in patients with muscle weakness and cramping after exercise. The inheritance is autosomal recessive and the heterozygote frequency is estimated at about $1 / 30$. In this study, we determined a cDNA sequence encoding human erythrocyte type AMP deaminase and identified gene mutation responsible for the deficiency.

The $3.7 \mathrm{~kb}$ cDNA defined by the screening of human spleen cDNA library and by some techniques utilizing polymerase chain reaction (PCR), contains an open reading frame of $2301 \mathrm{bp}$ which encodes 767 amino acids chain resulting in $89 \mathrm{kDa}$ protein. The homology to human muscle type AMP deaminase showed $64 \%$ identity at the nucleotide level in the area of open reading frame, and $60 \%$ similarity at the deduced amino acid level.

From the analysis of the entire coding region of the mutant genes using RT-PCR and direct-sequencing, a point mutation of $\mathrm{C}$ to $\mathrm{T}$ resulting in a single amino acid substitution of Arg to Cys was detected in both two B-cell lines derived from complete deficiency of human erythrocyte type AMP deaminase. The analysis for genomic DNA demonstrated that two complete deficient individuals were homozygous for the detected mutation, and two partial deficient individuals were diagnosed as heterozygous. 
DISRUPTION OF THE SITE FOR THE ERYTHROID SPECIFIC TRANSCRIPTION FACTOR IN THE GLOBIN GENE CAUSES $\delta$-THALASSEMIA

Miho MATSUDA, Norihiro SAKAMOTO, Yasuyuki FUKUMAKI

(Research Laboratory for Genetic Information, Kyushu University, Fukuoka 812, Japan)

$\delta$-Thalassemia is a condition characterized by impaired synthesis of the $\delta$-globin chain. The T-C substitution was detected at position -77 of the $\delta$-globin gene isolated from three independent Japanese homozygotes for $\delta$-thalassemia, while this base change was not detected in 116 alleles of normal individuals, thereby indicating the close association of this mutation with the thalassemia phenotype. Since the mutation (TTATCT-TCATCT) is located within the inverted binding motif of GATA-1, an erythroid cell-specific transcription factor, we performed gel retardation assay using nuclear extracts from the erythroid cells. We found that GATA-1 binds the oligonucleotide spanning positions -61 to -90 but does not bind to the oligonucleotide with the mutation at position -77 . Competition gel retardation assay revealed that GATA- 1 binding can be competed out by the fragment with the GATA-1 motif but not with the mutant oligonucleotide. Analysis of the transient expression of the CAT gene linked to the $\delta$-globin gene promoter region demonstrated that the construct with the mutant promoter region was expressed about 20 fold less compared with the normal one. Thus, the mutation at position -77 impairs $\delta$-globin gene expression by abolishing GATA-1 binding to the AGATAA sequence of the promoter region of the $\delta$-globin gene. This provides a good example of involvement of tissue-specific transacting factors in the molecular pathogenesis of hereditary diseases.

\section{A 30}

STRUCTURAL ORGANIZATION AND CHROMOSOMAL LOCALIZATION OF THE GENE FOR THE HUMAN Pit-1 AND GENOMIC ANALYSIS OF PATIENTS WITH MULTIPLE PITUITARY DEFICIENCIES. Kohji OHTA1, Yoshitaka NOBUKUNI1, Hiroshi MITSUBUCHI1, Yumi HAYASHIDA1, Tohru OHTA2, Takaya TOHMA2, Yoshihiro JINNO2, Shigehiro FUJIMOTO3, Fumio ENDO1 and Ichiro MATSUDA1 1Dept. Pediatr, Kumamoto Univ. Sch. Med., Kumamoto; 2Dept. Hum. Genet., Nagasaki Univ. Sch. Med., Nagasaki; 3Dept. Pediatr., Miyakonojyo National Hospital, Miyazaki.

Pit-1 is a pituitary-specific transcription factor that binds to and transactivates promoters of growth hormone- and prolactin-encoding genes. A chromosomal gene related to human Pit-1 isolated from human gene libraries was over $14 \mathrm{~kb}$ long and split into six exons. All of the splice donor and acceptor sites conformed to the GT/AG rule. The gene was mapped to human chromosome 3 by FISH. We analysed the Pit-1 gene of five patients with combined deficiency of GH, PRL and TSH. In three patients, we identified three point mutations in the Pit-1 gene, Pro24Leu, Arg143Gln, and Arg271Trp, located on the major transactivation region, POU-specific domain, and POU-homeodomain, respectively. When other mutations of Pit-1 gene are taking into account, it is suggested that mutant Pit-1 proteins act as dominant-negative mutant (in POU-homeodomain and transacivation region ) and a recessive mutant (in POU-specific domain). Two ( Pro24Leu andArg143Gln ) of three mutations are novel mutations. 


\section{A 31}

COMBINED PITUITARY HORMONE DEFICIENCY CAUSED BY A MUTATION IN THE PITI GENE; THE FIRST REPORT FOR A 'TRANSCRIPTION FACTOR DISEASE' WITH TARGET GENES.

Ke-ita TATSUMI*, Tsugunori NOTOMI*, Kiyoshi MIYAI*, Yuji MIZUNO', Hitoshi KOHNO $^{\ddagger} \&$ Nobuyuki AMINO* *Department of Laboratory Medicine, Osaka University Medical School, Osaka, Japan. +Fukuoka-higashi National Hospital, Fukuoka, Japan. ‡Fukuoka Children's Hospital, Fukuoka, Japan.

Although various cases of familial combined pituitary hormone deficiencies have been reported, none have been elucidated at the molecular genetic level. We present here the molecular basis of a hereditary case in which TSH, GH and PRL, are deficient. Similar combined hormone deficiency eported in two strains of mice, $d w$ and $d w^{J}$, are mutated in the gene for Pit-1/GHF-1, a pituitary specific transcription activator for the $G H$ and $P R L$ genes. The striking similarity between the patient and the mouse strains prompted us to examine her $P I T 1$ gene and those of her parents.

We determined nucleotide sequence of complementary DNA and genomic structure of the human PIT1 gene. Sequence comparisons using PCR amplified PIT1 gene sequences revealed only one nonsense mutation. The patient was homozygous with this mutation whereas her parents are heterozygous. The truncated peptide produced in the patient may well completely lose transcriptional activation activity as demonstrated in rat. Together with the fact that mutations in the gene for Pit-1/GHF-1 resulted in the combined deficiencies of TSH, GH and PRL in mouse, we conclude that the combined hormone deficiencies of the patient is ascribed to the nonsense mutation of the PIT1 gene.

\section{A 32}

MOLECULAR ANALYSIS OF METHYLMALONYL-CoA MUTASE DEFICIENCY. Masahito OGASAWARA, Hitoshi MIKAMI, Yoichi MATSUBARA and Kuniaki NARISAWA (Dept. Biochemical Genetics, Tohoku Univ. School of Medicine, Sendai)

Methylmalonyl-CoA (MCM) mutase deficiency is an autosomal recessive disorder characterized by metabolic acidosis and the accumulation of organic acids in body fluids. Previously we identified four discrete missense mutations in the MCM gene from eight Japanese patients. However, five of eight (62.5\%) patients expressed remarkably decreased amount of mRNA which could not be detected by Northern blot analysis. We were able to amplify and quantify the trace amount of mRNA $(0.1-1.0 \%)$ by RT-PCR coupled with Fluorescent Fragment Analyzer. Subsequently the trace amount of MCM mRNA was amplified by nested PCR to obtain sufficient amount of cDNA for sequencing analysis. Sequencing of the amplified cDNA revealed three novel mutations: a single base substitution ( $G$ to $T$ at nucleotide position 349 ) and $2 \mathrm{bp}$ - and $4 \mathrm{bp}$ deletion, respectively, which resulted in the premature termination by frame shift. The nonsense mutation (G349T) was identified in 5 of 16 (31\%) mutant MCM alleles and might be a prevalent MCM mutation among Japanese population. 
A 33

\author{
COMPLEMENTATION AND RT-PCR-SSCP ANALYSES OF MAPLE SYRUP \\ URINE DISEASE ( MSUD ). Yumi HAYASHIDA, Hiroshi MITSUBUCHI, \\ Yoshitaka NOBUKUNI, Kohji OHTA, Izumi AKABOSHI , Yasuhiro INDO, Fumio \\ ENDO and Ichiro MATSUDA (Dept. Pediatrics, Kumamoto University School of \\ Medicine, Kumamoto )
}

MSUD is an autosomal recessive disease caused by structural changes that alter the normal function of any one of subunits, E1 $\alpha, \mathrm{E} 1 \beta$ and $\mathrm{E} 2$ of the branched-chain $\alpha$ -keto acid dehydrogenase complex ( $\mathrm{BCKDH}$ ). To clarify mechanism involved in MSUD, measurements of enzyme activity in cultured cells, complementation analysis and immunoblot analysis have been done. Then molecular defects of $\mathrm{E} 1 \alpha, \mathrm{E} 1 \beta$ and E2 have been identified using RT-PCR-sequence analysis. In some cases it was difficult to find which component of $\mathrm{BCKDH}$ was primary affected using immunoblot analysis. Therefore we established following methods: 1) identification of involved subunit by complementation analysis using three different cell lines derived from homozygotes identified to have $\mathrm{E} 1 \alpha, \mathrm{E} 1 \beta$ or $\mathrm{E} 2$ mutant gene. 2) screening of mutation site on cDNA of each subunit by RT-PCR-SSCP ( reverse transcriptase - polymerase chain reaction - single strand conformational polymorphism ). 3) mutation analysis by sequencing amplified cDNA fragment. Using these three methods, we could detect several novel mutations. These approach will facilitate mutation analysis of patients with MSUD.

\title{
A 34
}

GENE ANALYSIS OF MAPLE SYRUP URINE DISEASE(MSUD) Hiroshi MITSUBUCHI, Yumi HAYASHIDA, Yoshitaka NOBUKUNI, Kohji OHTA, Izumi AKABOSHI, Yasuhiro INDO, Fumio ENDO and Ichiro MATSUDA (Dept. Pediatrics, Kumamoto University School of Medicine, Kumamoto )

Seventeen patients with MSUD were examined using unique methods described in A-33. Defects of $E 1 \alpha, E 1 \beta$ and E2 subunits were suspected in 8, 5, and 4 patients, respectively ,by complementation analysis. And mutation site on cDNA of each subunit was screened by RT-PCR-SSCP.Then mutation was determined by sequencing amplified cDNA fragment. Nine single base missense mutation: R115W, Y122N, R123Q, Q156K, I169T, A209T, I282T, R319W and 3 bp deletion were identified in $\mathrm{E} 1 \alpha$ subunit. A single base missense mutation H156R, three frame shift mutations and aberrant splicing were identified in E1 $\beta$ subunit. A single base missense mutation and 125 bp insertion were identified in E2 subunit. All except one (11bp deletion) were novel mutations. Sites of amino acid substitution were all conserved in other species. Two patients (KM09 and KM22) had a same mutation (A209T) of E1 $\alpha$ subunit. In this mutant, altered secondary structure of $\mathrm{E} 1 \alpha$ protein was predicted by computer analysis. There is an extreme heterogeneity of mutations causing MSUD. 


\section{A 35}

MOLECULAR ANALYSIS OF MITOCHONDRIAL ACETOACETYL-COENZYME A THIOLASE DEFICIENCY: IDENTIFICATION OF GENE MUTATIONS IN TWO PATIENTS AND IN VIVO EXPRESSION ANALYSIS OF THESE MUTATIONS. Akihiro WAKAZONO, Toshiyuki FUKAO, Seiji YAMAGUCHI, Masatsugu KANO, Tadao ORII, (Department of Pediatrics, Gifu University School of Medicine) and Takashi HASHINOTO. (Department of Biochemistry, Shinshu University School of Medicine)

Mitochondrial acetoacetyl-coenzyme A thiolase (T2) deficiency ( $\beta$ Retothiolase deficiency) is an inborn error of isoleucine and ketone body catabolism. Here we describe the molecular events in another two probands(GKII and GK16) at the protein, CDNA and gene levels. GKII was identified as a compound heterozygote of N158D and T297M. GK16 was also a compound heterozygote of $\mathrm{A} 301 \mathrm{P}$ and $\mathrm{a}$ gt to $\mathrm{tt}$ transversion at the $5^{\prime}$ splice site of intron 8 , causing the exon 8 skipping. We transfected sV40-transformed GK03's fibroblasts with normal T2 CDNA and four mutant cDNAs. Enzyme assay and immunoblot analysis of these cells ensured that these mutations are responsible for $\mathrm{T} 2$ deficiency.

\section{A 36}

DIRECT EVIDENCE FOR A HOT SPOT OF GERMLINE MUTATION AT HPRT LOCUS.

Shin FUJIMORI, Tetsuo TAGAYA, Noriko YAMAOKA, Ryohei YOSHIMURA, Hirobumi SAITOH, Ieo AKAOKA (2nd Dep. Int. Med. Teikyo Univ. Sch. Med. Tokyo), and Naoyuki KAMATANI (Inst.Rheumatol. Tokyo Women's Med. College, Tokyo)

Germinal HPRT mutations that result in complete HPRT deficiency are responsible for the distictive, heritable Lesch-Nyhan syndrome. By several molecular analyses, the genetic abnormalities causing HPRT deficiency are considered to be strikingly heterogeneous, but we can find identical mutations in some different HPRT mutants. A newly identified point mutant HPRT Kanagawa with a $\mathrm{C}$ to $\mathrm{T}$ nucleotide substitution in codon 51 had an identical mutation to previously defined variants, HPRT Fujimi(Japan), HPRT Shefford(U.K.), 754-4(U.S.A.). HPRT Kanagawa and HPRT Fujimi were isolated from two unrelated Japanese Lesch-Nyhan patients, K.F. and T.H., respectively. In these variants, the nucleotide substitutions cause the loss of a Taq I site. The amplified fragments contaning the mutation site from genomic DNAs extracted from peripheral white blood cells derived from K.F. and T.H. by PCR were not cleaved by Taq I, whereas the DNAs from their mothers and fathers were completely didested by same restriction enzyme. These results revealed that the two mutations in HPRT Kanagawa and HPRT Fujimi were de novo events, suggesting the exsistence of mutational hot spot at HPRT locus. 


\section{A 37}

MOLECULAR ANALYSIS OF THE SECOND FEMALE LESCH-NYHAN PATIENT. Nobuaki OGASAWARA, Yasukazu YAMADA, Haruko GOTO (Department of Genetics, Institute for Developmental Research, Aichi Prefectural Colony, Kasugai, Aichi 480-03) Takeo YUKAWA and Hirofumi AKAZAWA (Ehime Disabled Children's Hospital, Matsuyama City, Ehime 790)

HPRT locus is on long arm of X chromosome, $q 26$ and because of inability of reproduction in Lesch-Nyhan patient, this disorder occurs only in males. However, 10 years ago, the first unusual female Lesch-Nyhan patient was found in Aichi Prefectural Colony. Recently, the second female patient was found in Ehime Disabled Children's Hospital.

The second patient is now 11 years old. The patient has normal karyotype, and her erythrocyte HPRT activity was about $6 \%$ of the control. The patient is $\mathrm{mRNA}^{+}$phenotype. Direct sequence analysis of cDNA synthesized by PCR showed that the majority had the mutation at codon 51 , CGA (Arg) to TGA (stop). Genomic analysis indicated that the patient was heterozygous for this mutation, and the mother was normal. Cloning experiments demonstrated the existence of about 1/10 amount of cDNA with no mutation on the entire coding region. The existence of small amount of normal mRNA might be due to the regulatory defect or predominant inactivation of normal HPRT gene carrying X chromosome.

\section{A 38}

MOLECULAR ANALYSIS OF THE UMP SYNTHASE cDNA IN A PATIENT AND HER FAMILY OF HEREDITARY OROTIC ACIDURIA(TYPE I). Takashi TSUBOI, Takaya ODA, Mariko SUCHI and Yoshiro WADA (Department of Pediatrics, Nagoya City Univ. Medical School, Nagoya)

Hereditary orotic aciduria (type I) is a rare autosomal recessive disorder characterized by megaloblastic anemia, leukopenia, retarded growth and development and increased urinary excretion of orotic acid. This disease results from the deficient or decreased activity of orotate phosphoribosyl transferase(OPRT) and orotidine-5'-phosphate decarboxylase(ODC), the enzymes that catalyze the conversion of orotic acid to uridine-5'-phosphate(UMP). In human, single protein catalyses both enzyme reactions. This bifunctional protein is designated as UMP synthase(UMPS).

In order to determine the molecular basis of the disease, RT-PCR and direct sequencing analysis were performed of mRNA derived from B-lymphoblastoid cell lines of the patient and her family. We identified two missense mutations in the UMPS cDNA from the patient.One is a T-to-G change at codon 109 (GTA $\rightarrow$ GGA), resulting in a single amino acid substitution of Val for Gly (subsequently designated V109G mutant). The other is an A-to-G change at codon 96 ( $\mathrm{AGA} \rightarrow \underline{\mathrm{GGA}}$ ), resulting in a single amino acid substitution of Arg for Gly (R96G mutant). Analysis of the UMPS cDNA from the family indicated that the patient was a compound heterozygote; V109G mutant allele was derived from father and R96G mutant allele was derived from mother. And the other two children in this family were both heterozygous for UMPS gene, V109G allele and normal allele. 
DNA ANALYSIS FOR APRT DEFICIENCY HAVING 4 BASE INSERTION Hiroko HIGASHIMOTO, Ryuji KAWAGUCHI , Kazumasa HIKIJI (Genetic Research Laboratory ,SRL Inc., Tokyo) and Yasushi INOUE (Saiseika isui ta Hospital,0saka)

Adenine phosphoribosyltransferase (APRT) deficiency is a genetic disorder involving 2,8-dihydroxyadenine(2,8-DHA) urolithiasis and renal failure among Japanese. It is known that there are two types of causative genes for this deficiency ; APRT ${ }^{*} J$ and $A P R T^{*} Q 0$, and we can detect them in almost all patients with Japanese APRT deficiency.

We analyzed 6 DNA samples $(A \sim F)$ who have developed 2,8-DHA urolithiasis, in spite of having their normal sequences, instead of having mutated form , $A P R T^{*} J$ and/or $A P R T * \infty$. In three samples of them, we detected the insertion of 4 bases (CCGA) in exon 3 (nt 1416 1419) ; homozygous in sample $A$ and D, and heterozygous in sample $F$, using the cloning and dideoxy sequencing methods. Although we have sequenced of all 5 exons, we could not find any mutation in sample $B, C$ and $E$. Now we are proceeding the further analysis based on the idea that sample $B, C$ and $E$ might have the mutation other than J,Q0, and newly formed mutation described above.

\section{A 40}

DETECTION OF APRT*J AND OTHER MUTANT ALLELES BY THE SINGLESTRAND CONFORMATION POLYMORPHISM (SSCP) ANALYSIS. Chihiro TERAI, Sanae OTSUKA, Naoyuki KAMATANI, and Sadao KASHIWAZAKI (Institute of Rheumatology, Tokyo Women's Medical College, Tokyo)

Patients with adenine phosphoribosyltransferase (APRT) deficiency develop dihydroxyadenine (DHA) urolithiasis. Two types of APRT deficiencies are known and type II defect is common in Japan. $A P R T^{*} J$ is a mutant allele found in type II defect and its gene frequency is estimated to be approx. $0.42 \%$ among Japanese. Based on linkage disequilibrium analysis of RFLP sites near APRT gene, $A P R T^{*} J$ allele is indicated to derive from a single mutation appeared tens of thousand years ago. Although patients with type II APRT deficiency (homozygote of $A P R T^{*} J$ ) have been so far found only in Japan, $A P R T^{*} J$ gene might be widely spread among Mongoloid. To detect in a more rapid and simple way $A P R T^{*} J$ allele in larger population, we used the PCR-SSCP technique. Using two PCR primers giving 407 bp DNA covering $A P R T^{*} J$ mutation site on exon 5 , we could identify $A P R T^{*} J$ allele from $A P R T^{*} 1$ allele in B cell line DNA samples from patients and family members of DHA urolithiasis. We examined 295 Taiwanese and 63 Korean blood samples with this method and found no $A P R T^{*} J$ allele so far, but 3 other unknown mutant alleles. 


\section{A 41}

Molecular Basls of Mucopolysaccharldos is NA; I Tatsuga OGAFA, Shunjl TOMATSU, Se 1 l 1 FURUDA, Michi ya MASUR, Kazuro SUREGATA, Tadao ORII (Dept. Pedlatr., GI fu Univ. school of Medicine, Giful

ムコ多䑧㧫NA型はN-ace tylga lactosamine-6-sulfate sulfatase (GalNAc6S-sulfatase) の異常による常染色体少性遭伝性族患であり、䠛床症状としては、低身長、軟骨内骨化

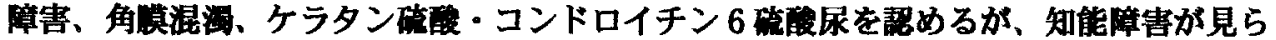
れないことを特徽とする。患者間においてその䁘床症状にはかなりの相虺がみられ、重

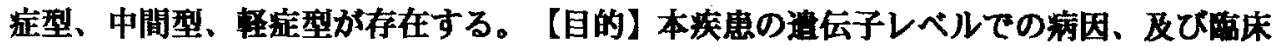

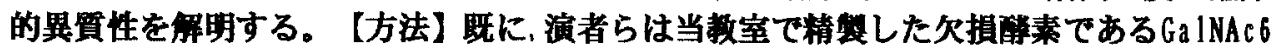
S-sul f ataseのcDNAクローニングを行ない全埴基因列を决定し、重症型 1 倒 (Case 1)、重 症型 2 例 (Case283) の日本人患者につきPCR法によりcDNAクローニングを行ない变異部位 を決定したが、今回更に同棣の方法で日本人中間型 2 例 (Case 586)についても変異部位 の同定を陆みた。【結果】Case 5は险床的には中間型で、軽症例であるCase 243のもつN2 04Kの変異と新たに見つかったR93Gの変異とのへテロ接合体であった。また、Case6も中 間型であるが、重庭型にホモでみられたlarge deletlonと今回啹告したV138Aの楆異と のへテロ接合体であった。Case5については、PCR法と制眼放素解析を組み合わせること で家系解析も可能であった。また、各㚆異について変異部位を発現べクターに組み込み

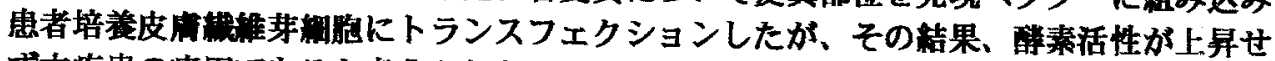
ず本笂患の病因でると考えられた。

\section{A 42}

Moleculat Basis of Mucopolysaccharidosis INA; I Toshinori HORI, Shunj i TOMATSU, Yoshihi ro NARASHIMA, Atsushl UCHIYAMA, Yuko FUKUDA, Mitsuo MASUNO, Sel]I FUKUDA, Kazuho SUKEGAWA, Tadao ORII (Dept. Pediatr., Gifu Unir. School of Medicine, Gifu)

[目的及び方法］ ムコ多糖症IVA型はN-acetylgalactosamine-6-sulfate sulfatase (GalNAc-6́s sulfatase)の異常による常染色体劣性遺伝性疾患であり、我々は、既にこの 醿素の全長 CDNAをクローニングした。今回、その病因解析のため、この全長cDNAをプロー ブとしてゲノムDNAスクリーニングを行い、さらに染色体上の遺伝子座位を決定するため

に、スクリーニングにて得られた3種類のゲノム断片をプローブとして、fluorescence in situhybidization法により遺伝子の染色体マッピングを行った。また、正常人20例及 び日本人モルキオ病患者14例について CDNAプローブを用いてサザンブロッティングを行つ た。[結果］ 1) ヒトגEXBL3ゲノミックDNAライブラリーのスクリーニングにより、GaINA c-6s sulfatase遺伝子の全長をクローニングした。解析の結果、その鎖長は約50Kbで14の EXONに分かれ、プロモーター領域に4つGC boxを誋めた。2) insituhybridiationの結果 、用いた3種類のどのプローブにおいてもGalNAc-6S sul tatase遺伝子の染色体上の座位が 16亿24であることが確認された。3）゙゙ラミックサザンブロッティングの結果、患者14例中1 例にホモ、3例にへテロのrearangementが認められ、4例とも同一のパターンを示すこと より、同じ機序に基づく変異であることが示睃された。さらにこのホモの1例で仕、独立 した異なる2カ所の欠失が示晙され、現在解析中である。 


\section{A 43}

GALACTOSIALIDOSIS: MUTATIONS AND PROPERTIES OF THEIR EXPRESSION PRODUCTS

Michie SHIMMOTO, Kohji ITOH, Akihiro OSHIMA, Hitoshi SAKURABA, Yoshiyuki SUZUKI.(Clinical Genetics, The Tokyo Metropolitan Institute of Medical Science)

Galactosialidosis is an inherited metabolic disease characterized by a combined deficiency of lysosomal $\beta$-galactosidase and neuraminidase due to the genetic defect of protective protein(PP). It regulates their activities by forming a high molecular weight aggregate and has a carboxypeptidase activity by itself. The clinical manifestations of this disease are heterogeneous. In this study, one common mutation $746 \mathrm{~T}-$ to $_{\mathrm{A}} \mathrm{A}$ (Y249N) was indentified in two Caucasian patients with atypical clinical courses which were reported as "late-infantile type". They show less severe manifestations than Japanese infantile patients in spite of their early onset. The Y249N mutant clone, transiently expressed in a transformed galactosialidosis cell line, produced a small amount of catalytic activity of carboxypeptidase, and restored $\beta$-galactosidase and neuraminidase activities to some extent. Futhermore pulse-chase analysis detected a small amount of the mature form, as well as the precursor, in the cells transfected with the mutant cDNA. So we concluded that the mutation Y249N, expressing some amount of functional protein, contributed to the mild phenotypic expression in galactosialidosis.

\section{A 44}

CARBAMYL PHOSPHATE SYNTHETASE I DEFICIENCY ; ONE BASE SUBSTITUTION IN AN EXON OF THE CPS I GENE CAUSES A 9 BASE PAIR DELETION DUE TO ABERRANT SPLICING. Ryuuji HOSHIDE, Toshinobu MATSUURA, Yougo HARAGUCHI, Fumio ENDO, Ichiro MATSUDA(Department of Pediatrics, Kumamoto University School of Medicine, Kumamoto) and Muneyoshi YOSHINAGA (Nagasaki-Chuo National Hospital, Nagasaki)

Carbamyl phosphate synthetase I (CPS I; EC6,3,4,16) is an autosomal recessive disorder characterized by hyperammonemia. We studied the molecular bases of CPS ] deficiency in a Japanese newborn girl with consanguineous parents. Northern and Western blots revealed marked decreases in CPS I mRNA and enzyme protein but with a similar size as that of the control, respectively.Sequencing of the patient's cDNA revealed 9 nucleotides deletion at position 832-840. Sequencing analysis of the genomic DNA revealed a $\mathrm{G}$ to $\mathrm{C}$ transversion at position 840 , the last nucleotide of an exon in the splice donor site. This substitution altered the consensus sequence of the splice donor site and a newly cryptical donor site appeared in the exon that caused the 9-bp in frame deletion. This report seems to be the first complete definition of CPS I deficiency, at the moleculas level. 


\title{
A 45
}

Characterization of mutations in 11 Japanese patients with ornithine transcarbamylase deficiency : Toshinobu MATSUURA ${ }^{1}$, Ryuuji HOSHIDE ${ }^{1}$, Emiko KOIKE ${ }^{2}$ and Ichiro MATSUDA ${ }^{1}$ ('Department of Pediatrics, Kumamoto University Medical School. ${ }^{2}$ Department of Clinical Laboratory, Kumamoto City Medical Association.)

OTC deficiency ( an X-linked disease ) is liver-specific enzyme that catalyzes the second step of the urea cycle. Many patients have hyperammonemia, coma, and death in childhood. We analyze mutations responsible for OTC deficiency in 18 Japanese patients; 9 male patients with neonatal onset type ( $=<28$ days), 5 male patients with late onset type (> 28 days), 4 female patients. We performed the PCR to amplify all exons and exon/intron junctions, following the PCR-SSCP with silver staining. In 11 patients ( 7 males, 4 females), we detected exons which showed abnormal mobility by PCR-SSCP, and in which there were 8 missense mutations, a nonsense mutation, 2 one point mutations resulting in aberrant splicing.

\section{A 46}

\author{
A POINT MUTATION ON FAH GENE FROM A JAPANESE PATIENT WITH \\ TYROSINEMIA TYPE1. Hisataka AWATA, Fumio ENDO, Akito TANOUE, \\ Ichiro MATSUDA (Dept. Pediatrics, Kumamoto University School of Medicine, \\ Kumaoto)
}

A defect in the Fumarylacetoacetate hydroxyrase(FAH) is the cause of tyrosinemia type 1 characterized by liver and renal tubular disfunction and hypertyrosinemia. We revealed which is that the human FAH gene was $42 \mathrm{kilobases}$ long and was spilit into 13 exons. Then, we have analyzed the FAH gene from a patient who had died from liver disfunction with hypertyrosinemia. The peripheral lymphocytes from the patient had no FAH activity and no FAH antigen. A point mutation from $185 \mathrm{~T}$ to $185 \mathrm{G}$ that caused amino acid replacement of 62Phe by 62Cys was discovered in cDNA from mRNA extracted from patient's fibroblast. The DNA fragment of FAH exon2 was amplified by PCR and was sequenced by direct-sequence method. It was confirmed that the patient was homozygous for the mutation. The mutant cDNA was inserted into a plasmid expression vector pcAGGS and transfected to BMT-10cell. FAH activity was not detected in the cell after the transfection of the mutant cDNA.

Thus, we have characterized the FAH gene structure and detected a point mutation on the DNA from tyrosinemia typel patient. 
A 47

TWO MISSENSE MUTATIONS OF PHENYLKETONURIA IN JAPAN BY PAHCDNA ANALYSIS FROM CULTURED LYMPHOBLAST. Yoshiyuki OKANO, Gen ISSHIKI (Dep. Pediatr., Osaka City Univ. Med. School Osaka), Yutaka HASE (Osaka Childr. Med Cent., Osaka), Toshiaki OURA (Osaka Municipal Rehab. Cent. for the Disabled, Osaka)

Classical phenylketonuria (PKU) is caused by a deficiency of hepatic phenylalanine hydroxylase $(\mathrm{PAH})$. We found two missense mutations in Japanese from PAHcDNA of cultured lymphoblast cell. The total RNA prepared from cultured lymphoblast cell was reverse-transcribed into PAH cDNA and was nest PCR amplified. Double-stranded te $m$ plate was subcloned into M13mp18 and was sequenced. A C-to-T transition at the first base of codon 241 results in the substitution of Arg for Cys, and a G-to-A transition at the second base of codon 408 results in the substitution of Arg for Gln. Both mutations were linked to RFLP haplotype 4 among Japanese. Population genetic studies revealed that R241C accounted for 3.9\% and R408Q accounted for $1.3 \%$ in Japanese PKU alleles. R408Q mutation found in North Europe is linked to RFLP haplotype 12, and occured independently among Caucasians and Orientals.

\section{A 48}

STRUCTURE OF HUMAN PYRUVATE KINASE L-GENE AND ITS GENETIC VARIATION. Hitoshi KANNO, Shiro MIWA (Okinaka Memorial Institute For Medical Research, Tokyo) and Hisaichi FUJII (Tokyo Women's Medical College, Tokyo)

The human L-type pyruvate kinase (PK) gene has been cloned and partial nucleotide sequences were determined. The gene is organized in 12 exons over 9.5-kilobase pairs, and the first and second exon are specifically transcribed to the R-and L-type PK mRNA by the tissue-specific promoters. The 5'-flanking region upstream the first exon (exon R) has two CACCC boxes and four GATA motifs and the region showed a potent promoter activity in K562 erythroleukemic cells. We have identified four missense mutations of the L-type PK gene in Japanese PK variants associated with hereditary hemolytic anemia; T384M, Q421K, R426Q and V368F. These amino acid substitutions occurred near a potassium $\left(\mathrm{K}^{+}\right)$binding site of PK subunit. Because $\mathrm{K}^{+}$is essential for substrate binding, the mutation might account for the decreased affinity for phosphoenolpyruvate (PEP). A silent mutation $(1705 \mathrm{~A} \rightarrow \mathrm{C})$ was identified in normal individuals as well as in individuals with $\mathrm{PK}$ variants, and the nucleotide polymorphism might be used for a genetic marker of human chromosome 1 . 
A 49

MOLECULAR ANALYSIS OF VITAMINE B -RESPONSIVE PYRLVATE DEHYDROGENASE DEFICIENCY IN TWO PATIENTS WITH CONGENITAL IACTIC ACIDEMIA. Etsuo NAITO, Michinori ITO, Ichiro YOKOTA, Takahiko SAIJO, Eiji TAKEDA, Yasuhiro KURODA (Dept. Pediatr. Tokushima Univ., Tokushima), Satoshi YOSHIJIMA, (Dept.Pediatr.Saiseikai Nakatsu Hosp.,Osaka) and Mitsuo MAEHARA (Chubu National Hosp., Aichi)

We examined the molecular basis of thiamine dependency in two patients with vitamine B -responsive lactic acidemia. Their cultured lymphoblastoid cells reduced activity of pyruvate dehydrogenase (PDH, E), and showed decreased affinity of PDH for thiamine pyrophosphate (TPP) and defect of PDH activation. In the $\mathrm{E} \alpha$ cDNA of one patient only one $c>r$ transition was identified at position 131, resulting in the substitution of Arg-44 with His-44. These results suggested that this mutation led to the conformational changes of $E_{1} \alpha$ subunit, resulting in the decreased affinity for top and the defective activation of $\mathrm{PDH}$. This mutation must be a de novo mutation, because it is not found in either parent"s genomic DNA. We are analyzing the molecular basis of the other patient.

\section{A 50}

FOUR CASES WITH ISOLATED DEFICIENCY OF PEROXISOMAL B-OXIDATION ENZYMES. - DIAGNOSIS BY A COMPLEMENTATION ANALYSIS -

Yasuyuki SUZUKI, Nobuyuki SHIMOZAWA, Shigehiro YAJIMA, Kyoko INOUE, Tadao ORII (Dept. Pediatrics, Gifu Univ. Sch. Med., Gifu)

Peroxisomal B-oxidation system consists of three enzymes, acyl-CoA oxidase, bifunctional protein and 3-ketoacyl-CoA thiolase, and plays an important role in the degradation of very long chain fatty acids. Patients with isolated deficiency of these enzymes manifested severe neurological symptoms similar to those of peroxisome-deficient disorders. However, the reported cases with deficient these enzymes are rare since measurement of each activity is difficult and the diagnosis is mainly done by immunoblotting. Here we report each two cases with acyl-CoA oxidase deficiency and bifunctional protein deficiency. Lignoceric acid oxidation activity was severely deficient in all the patients. However, cross-reactive material of all peroxisomal $B-o x i-$ dation enzymes was detectable. Diagnosis was performed by a complementation study using authentic cell lines with defective acyl-CoA oxidase or bifunctional protein. Complementation was assessed by the restoration of lignoceric acid oxidation in the fused cells. This method is useful for the diagnosis of peroxisomal B-oxidation enzyme deficiency with detectable enzyme protein. 


\section{A 51}

PRENATAL DETECTION OF PEROXISOMAL DISORDERS. Nobuyuki SHIMOZAWA, Yasuyuki SUZUKI, Shigehiro YAJIMA, Kaoru IZAI, Tadao ORII (Dept. Pediatr., Gifu Univ.), Hajime NAKAMURA (Dept. Pediatr., Kobe Univ.) and Kiyokuni MIURA (Dept. Child Neurol., Aichi Colony)

Peroxisomal disorders are genetic metabolic discases with about twelve different disorders, which manifest severe neurologic symptoms. Although the prognosis of these disease are almost poor, there is no effective therapy. We performed 2 prenatal diagnosis of peroxisomal disorders including Zellweger syndrome(ZS) and rhizomelic type chondrodysplasia punctata (RCDP).

[Case 1] A fetus had an elder sister with ZS due to the deficiency of peroxisome assembly factor-1 (PAF-1). In the amniotic fluid cells, catalase-positive particles (peroxisomes) were detected immunocytochemically and dihydroxyacetone phosphate acyltransferase (DHAP-AT) activity was normal. Further amniocytes DNA analysis showed the heterozygous mutation in the PAF-1 gene, so this fetus was diagnosed as a carrier.

[Case 2] A fetus had an elder sister with RCDP who showed biochemical abnormalities of intracellular processing of 3-ketoacyl-CoA thiolase and DHAP-AT activity. In the fetus, these biochemical abnormalities were not detected.

\section{A 52}

ANALYSIS OF MITOCHONDRIAL FATTY ACID $\beta$-OXIDATION ENZYME ACTIVITIES FROM THE PATIENTS WITH REYE'S SYNDROME AND SUDDEN INFANT DEATH. Akira OHTAKE, Hitoshi SAKURABA, Yoshiyuki SUZUKI (Dept. Clin. Genet., The Tokyo Metro. Inst. Med. Sci., Tokyo), Toshiaki KOHGO, Hiroki ABE, Shigenor i YAMAMOTO, Hi roo NIIMI (Dept. Pediatr., Chiba Univ. Sch. Med., Chiba), Masaki KaNAZAWA, Masaki TAKAYANAG (Div. Met., Chiba Chidren's Hosp., Chiba), Takehiko KaMIJO and Takashi HASHIMOTO (Dept. Biochem., Shinshu Univ. Sch. Med., Matsumoto)

We have developed assay systems which can determine the exact location of a defect in the mitochondrial fatty acid $\beta$-oxidation, using enzymatically synthesized substrates. Cultured fibroblasts or EB virus-transformed 1 ymphoblasts were obtained from 10 patients with REYE's syndrome, sudden infant death and hypoketotic dicarboxylic aciduria. Long-chain 3-hydroxyacyl-CoA dehydrogenase deficiency was demonstrated in fibroblasts from one Caucasian patient. The value of cultured lymphoblasts in the diagnosis and evaluation of inherited disorders of mitochondrial fatty acid $\beta$-oxidation was also demonstrated. 
A 53

DETECTION OF A NOVEL VARIANT TRANSTHYRETIN (50Ser TO Ile) GENE IN FAMILIAL CARDIAC AMYLOIDOSIS BY DNA CONFORMATION POLYMORPHISM ANALYSIS Haruhito HARADA ${ }^{1) 2}$, Akinori KIMURA $^{1)}$, Hirofumi NISHI $^{1}{ }^{2)}$, Yasuo HAYASHI ${ }^{3)}$, Motoomi NAKAMURA $^{3)}$, Hironori TOSHIMA ${ }^{2)}$, and Takehiko $\underline{\text { SASAZUKI }}^{1)}$, 1)Dept. Genet., Med. Inst. Bioreg., Kyushu Univ. Fukuoka, 2)Third Dept. Int. Med., Kurume Univ. Kurume, 3)Sanshinkai-Hara Hospital, Fukuoka

We analyzed the transthyretin (TTR) gene from four patients with systemic amyloidosis by polymerase chain reaction-DNA conformation polymorphism (PCR-DCP) analysis. Genomic DNA prepared from peripheral blood leukocytes was subjected to PCR to amplify separately the four exons of the TTR gene. The PCR products were denatured and electrophoresed in a non-denaturing polyacrylamide gel to detect by silver staining the electrophoretic change of DNA fragments due to a sequence variation. An unusual DNA fragment was observed in the PCR products of the exon 3 from a patient with familial cardiac amyloidosis. Subsequent sequencing analysis revealed a variant transthyretin gene with a replacement of Ser (AGT) by Ile (ATT) at codon 50. The observation that the Ser to Ile change at codon 50 is associated with cardiac amyloidosis whereas the Ser to Arg change at the same codon is associated with polyneuropathy suggest that the nature of each variant TTR determines the preferencially depositing organs. The PCR-DCP analysis is a sensitive, simple, and rapid method to detect a sequence variation in the human genome and thus is an useful screening method for causative mutations in hereditary disease.

\section{A 54}

STRUCTURE OF THE GENE ENCODING HUMAN T-PROTEIN OF THE GLYCINE CLEAVAGE SYSTEM AND ITS LOCALIZATION TO 3p21.1-p21.2. Kenji NANAO, Kiyoshi HAYASAKA, Yoriko KOMATSU, Goro TAKADA (Dept. Pediatr., Akita Univ., Akita) Kazuko OKAMURA-IKEDA, Yutaro MOTOKAWA (Inst. Enzy. Res., Tokushima Univ., Tokushima) Naohiko SEKI and Ei-ichi TAKAHASHI (Div. Genet., Natl. Inst. Radiol. Scie., Chiba)

Human $\mathrm{T}$-protein deficiency in the glycine cleavage system causes non-ketotic hyperglycinemia. To elucidate the molecular defects of this inherited disease, we determined the structure of the human T-protein gene. Genomic clones were isolated by screening human placental cosmid library with human T-protein cDNA and studied by restriction mapping, polymerase chain reaction analysis, and DNA sequencing. The gene is about 6 kilobases in length and consisted of nine exons separated by eight introns. The exon-intron junction sequences all conform to the GT/AG rule. The 5'-flanking region of the gene lacks typical TATAA sequence but has a single defined transcriptional initiation site detected by the primer extension method. No cluster of $\mathrm{CpG}$ doublet sequence was found. Two putative glucocorticoid responsive element and a putative thyroid hormone responsive element are present. The gene for $\mathrm{T}$-protein was assigned to the subband $3 \mathrm{p} 21.1-\mathrm{p} 21.2$ by fluorescence in situ hybridization. 
A 55

MOLECULAR CLONING OF CDNA FOR HUMAN LIVER HOLOCARBOXYLASE SYNTHETASE. Yasushi CHIBA $^{1,2}$, Yoichi SUZUKI ${ }^{1}$ Akihiro IWAMATSU $^{3}$, Kuniaki NARISAWA $^{1}$ (Dept. ${ }^{1}$ Biochem. Genet. and ${ }^{2}$ Pediatr., Tohoku Univ. School of Medicine, Sendai; ${ }^{3}$ Kirin Brewery Co. Ltd., Central Laboratories of Key Technology, Yokohama)

Holocarboxylase synthetase (HCS) is an enzyme which catalyzes incorporation of biotin into apo-carboxylases. Deficiency of HCS is known to cause neonatal form of multiple carboxylase deficiency (NMCD). To facilitate investigation of molecular basis of NMCD, isolation of cDNA for HCS is essential. We have developed a simple assay method for HCS and purified HCS from bovine liver. HCS was finally purified with SDS-PAGE and transferred to polyvinylidene difluoride membranes. The protein on the membranes was in situ-digested with three kinds of proteases. The resulting peptides were separated by HPLC and sequenced. A nucleotide probe was generated by mixed oligonucleotides primed amplification of human liver cDNA. Using this probe, we screened $\lambda$ gt 10 human liver cDNA library and isolated 12 positive clones with inserts of 2 to $2.5 \mathrm{kbp}$ in size. PCR amplification of DNA from the isolated clones revealed that all of them contained the identical sequence to the probe. Sequencing of the inserts from these clones is in progress.

\section{A 56}

GENOMIC IMPRINTING IN BECKTITH-WIEDEMANN SYNDROME. Takeo KUBOTA, Shinji SAITOH, Yoshihiro JINNO, Norio NIIKAWA (Dept. Hum. Genet., Nagasaki Univ. Sch. Med., Nagasaki, Japan)

Beckwith-Wiedemann syndrome (BWS) is a genetic disorder with overgrowth. A chromosomal region, 11p15.5, may contain the gene(s) responsible for BWS. Genomic imprinting at $11 \mathrm{p} 15.5$ is proposed: the paternal gene(s) is expressed, while the maternal gene(s) is inactive. We studied 18 BWS patients to ascertain the parental origin of the 11p15.5 region using DNA polymorphic markers.

In each of 2 cases of partial 11p15 trisomy, the additional 11p15 region was inherited from the father. Thus, they inherited two paternal $11 \mathrm{p} 15$ regions in total. In 13 of 16 patients with a normal karyotype, their homologues 11 were of biparental origin. Uniparental paternal disomy, both of chromosomes 11 were transmitted from the father, was not ruled out in the other 3 cases. Previous studies showed that in the mouse homologue of IGF2 only the paternal allele expresses and an excess paternal copy of this gene is responsible for growth enhancement in the mouse embryo. Since such an overgrowth of the mice resemble the BWS phenotype and both are related to an extra paternal copy, IGF2, which is mapped at 11p15.5, is the most likely candidate of the BWS gene. 
B 1

INCIDENCE OF CHONDRODYSTROPHY IN JAPAN, 1969-1985.

(Yoko Imaizumi, Institute of Population Problems, Ministry of Health and Welfare, Tokyo )

Nation-wide data in Japan on fetal and postnatal deaths of individuals with chondrodystrophy (ICD756.4) were analyzed during the period 19691985. The data consist of 307 fetal deaths and 182 postnatal deaths. The overall incidence of chondrodystrophy was 0.15 per 10,000 births. The geographical variations in the incidence were observed with the highest rate in Okinawa ( 0.34 per 10,000 births) followed by Kagawa, Fukushima, Tochigi prefectures (0.33), whereas the lowest was zero in Gunma, Siga, Tokushima, Saga, and Kagoshima prefectures. The incidence increased with the paternal age during the period 1979-1985. Overall mean age at death was 0.60 years for 1969-1978 and 1.06 for 1979-1985.

\section{B 2}

EPIDEMIOLOGY OF LIMB BODY WALL COMPLEX

Ken i KUROSAWA, Mitsuo MASUNO. Ki yoshi IMAIZUMI, Yoshikazu KUROKI (Div.Med.Genet., Kanagawa Children's Medical Center, Yokohama)

The diagnosis of $1 \mathrm{imb}$ body wall (LBW) complex was based on the presence of two out of three anomalies: exencephaly/encephalocele. with facial clefts; thoraco-and/or abdominoschisis; and limb defects. Eleven cases of LBW complex were registered in KAMP (Kanagawa Birth Defects Monitoring Program) during 9 years and 9 months from January 1982 to September 1991. Of the eleven subjects ( 6 female, 4 male, 1 unknown sex), 8 were stillbirth, 3 livebith, two of which resulted in perinatal death. The gestational age ranged from 23 to 39 weeks (31 weeks average), and average bith weight was $1080 \mathrm{~g}$. The mean maternal and paternal ages were 30.8 and 34.0 , respectively. No significant teratogenic factors were recorded in parental history. Most cases $(9 / 11)$ were diagnosed prenatally. The prevalence of LBW complex in KAMP was 0.26 . It was almost same as that in other population studies. 


\section{B 3}

GENETIC EPIDEMIOLOGY OF BREAST CANCER IN JAPAN-(1)FAMILIAL AGGREGATION-. Yasao KANAMORI(1), Takashi FUKUTOMI (2), Minoru SUGITA(1) and Takasi IZUN01) ((1)Dept. Environ. and 0ccup. Health, School of Nedicine, Toho Univ. Tokyo, (2)Dept. of Surgery, National Cancer Center Hospital, Tokyo)

Pedigree data of breast cancer were collected at the National Cancer Center Hospital. Results 1. An investigation of 245 family history of patients who operation therapy were done from January to December, 1990. a)Sporadic breast cancer is $87 \%$, 13\% demonstrated familial aggregation. b)By Segregation analysis, $p=0.068(p<=0.15)$. By assuming rare dominant inheritance (Bishops, Iselius, Newman), we results that Penetrance in Japan is lower than England. Japanese Expected Penetrance is $0.18-0.27$ at aged $40-59$, while that of England and Males(Iselius) is $0.39-0.54$ at aged 40-59. c)Mean coefficient by kinship between possible pairs of individuals, one from each set were 0.027. 2. An investigation of Case control study ( 132 cases:aggregation, controls: sporadic ), adjusted the age of the operation therapy. a)onset age of Aggregation is younger than that of Sporadic. b)Probability of cancer of Aggregation and Mean coefficient by kinship between cancer and cancer is higher than that of Sporadic (not significant).

B 4

PHYSICAL ORDERING OF 11 RFLP COSMID MARKERS ON 3p23-p21.3 BY MULTI-COLOR FLUORESCENT IN SITU HYBRIDIZATION. Johji INAZAWA $^{1}$, Takeshi ARIYAMA ${ }^{1}$, Kazuhiro YAMAKAWA ${ }^{2}$, Yusuke NAKAMURA ${ }^{2}$ and Tatsuo $\mathrm{ABE}^{1}$ ('Dept. Hygiene, Kyoto Pref. Univ. Med., Kyoto, ${ }^{2}$ Dept. Biochem., Cancer Inst., Tokyo)

We standardized multi-color FISH using two different fluorochrome dyes, FITC (green) and rhodamine (red). The third color was visualized as a pseudo-color (yellow) generated by optic interference with FITC and rhodamine. This system allowed us to determine rapidly and precisely the order of 11 polymorphic DNA loci on bands 3p23p21.3 which span a putative tumor suppressor gene(s) for renal cell carcinoma, lung carcinoma and ovarian tumors. The present multi-color FISH system can detect three different sequences simultaneously not only in metaphase chromosomes but also in interphase nuclei with discernible three-colors. This system may be useful for the precise ordering of three or more close sequences in interphase nuclei. 
B 5

APPLICATION OF GENETIC LINKAGE MAP OF HUMAN CHROMOSOME 8p IN SEARCH FOR TUMOR SUPPRESSOR GENES. Mitsuru EMI. Yoshiyuki FUJIWARA, Hiroyuki OHATA, Yusuke NAKAMURA (Dept. Biochem., Cancer Institute, Tokyo)

We have constructed a genetic linkage map of the short arm of human chromosome 8 with14 RFLP markers, including three genes, MSR, LPL, and NEFL, and 10 marker that we have isolated and physically localized to chromosomal bands by fluorescent in situ hybridization. This linkage map, spanning $45 \mathrm{cM}$ in males and $79 \mathrm{cM}$ in females, will be useful in linkage studies of human genetic diseases and in the development of high-resolution maps for this chromosomal region. Using these RFLPs, we observed frequent allelic losses on chromosome $8 \mathrm{p}$ in hepatocellular carcinoma, colorectal cancer, and non-small cell lung cancer. Deletion mapping in these tumors defined commonly deleted regions at $8 \mathrm{p} 23.1$ 8 p21.3, suggesting the presence of tumor suppressor genes for these types of cancer.

B 6

ISOLATION OF COSMID MARKERS AROUND THE MEN2A LOCUS. Katsu KARAKAWA $^{1}$, Koji TAKAMI ${ }^{1}$, Tsutomu NAKAMURA ${ }^{1}$, Shoichi FUJITA $^{1}$, Touru OHTA ${ }^{2}$, Takaya TOHMA ${ }^{2}$, Yoshihiro JINNO ${ }^{2}$, Norio NIIKAWA $^{2}$, Isamu NISHISHO ${ }^{1}$, Shin-ichiro TAKAI ${ }^{1}$ ( $^{1}$ Dept. Med. Genet., Biomedical Res. Center, Osaka Univ. Med. Sch., 2 Dept. Hum. Genet., Nagasaki Univ.)

Multiple endocrine neoplasia type 2 (MEN 2A) is a familial cancer syndrome transmitted in an autosomal dominant pattern with nearly complete penetrance, characterized by medullary thyroid cancer, pheochromocytoma and hyperparathyroidism. The predisposing gene has been mapped to the pericentromeric region of chromosome 10 by linkage analysis, but is not identified. In this study we used microdissection technique followed by primer-linker PCR method to construct plasmid library region-specific to $10 \mathrm{q} 11.2-21.1$, from which microclones were used to screen total human cosmid library. Now we isolated 194 microclones, and 23 cosmid clones by nine inserts of microclones which proved unique sequence on chromosome 10 . We are studying whether the cosmid clones reveal restriction fragment length polymorphism (RFLP). Mapping of them are being carried out by fluorescence in situ hybridization (FISH), linkage analysis, pulse field gel electrophoresis (PFGE), and radiation hybrid cell panel. 
B 7

MICRODISSECTION AND MICROCLONING OF GENOMIC DNA MARKER FROM HUMAN CHROMOSOME REGION 11q23. Naohiko SEKI , ${ }^{1,2}$ Masatake YAMAUCHI, ${ }^{1}$ Kou-ichiro YOSHIURA, ${ }^{3}$ Tohru OHTA, ${ }^{3}$ Norio NIIKAWA ${ }^{3}$ and Tadaaki $\underline{\text { HORI }}^{1}$ ( ${ }^{1}$ Div. Genet., Natl. Inst. Radiol. Sci., Chiba, ${ }^{2}$ Kazusa DNA Res. Inst., Chiba, ${ }^{3}$ Scool, Med., Nagasaki Univ., Nagasaki)

A human genomic DNA library was constructed by using microdissection- microcloning procedure with PCR techniques from chromosome $11 \mathrm{q} 23$ region. A total of 450 recombinant $\mathrm{pUC}$-clones was isolated from the library. Their insert sizes ranged from 150 to $850 \mathrm{bp}$ with a mean of $320 \mathrm{bp}$. Fifty pUC-clones were randomly selected and analyzed in detail. Southern blot analyses showed that $21(42 \%)$ clones were unique DNA sequences, $20(40 \%)$ clones were repetitive sequences, and $9(18 \%)$ clones have no detectable hybridization. The unique sequences were further used in secondary screening of a partiallydigested human genomic library constructed in phage-vector, and 4 clones were isolated. The chromosomal location of these phage-clones were confirmed to be at $11 \mathrm{q} 23$ region of human chromosome by using FISH technique.

\section{B 8}

COSMID CLONES FROM MICRODISSECTED CHROMOSOMAL REGION 15q11-q13. Toshiya TAMURA, Takaya TOHMA, Tohru OHTA, Hidenobu SOEJIMA, Yoshihiro JINNO, Norio NIIKAWA (Dept. Hum. Genet., Nagasaki Univ. Sch. Med., Nagasaki), Kazuhiro TSUKAMOTO, Yusuke NAKAMURA (Dept. Biochem., Cancer Inst., Tokyo)

With the purpose of isolating the gene(s) responsible for PraderWilli syndrome (PWS) and Angelman syndrome (AS), a chromosomal region, 15q11-q13, was first microdissected, the DNA was extracted and amplified by our primer-linker PCR method, and a microclone library was constructed. Of 102 microclones analyzed by Southern hybridization, 18 were single-copy clones. Then, a cosmid human genomic DNA library was screened using the single-copy microclones as probes, and 24 positive cosmid clones obtained underwent mapping with chromosome fluorescence in situ suppression hybridization (FISH). Of the 24 positive clones obtained, three were mapped at 15q11-q13, two at 15p11.2-p11.1, and three at 15cen. We are searching clones which drop into the smallest deletion among AS/PWS patients. This strategy is useful for isolating the PWS/AS genes. 
B 9

CONSTRUCTION OF PHYSICAL MAP AT CHROMOSOME BAND 17p13. Akira TANIGAMI, Johji INAZAWA, Hiroko SAITO, Takaaki SATO, Yusuke NAKAMURA (Dept. Biochem., Cancer Institute, Tokyo)

On the short arm of chromosome 17, it is reported that frequent LOHs at the distal region to TP53 are found and that this LOH and lymphnode metastasis correlates in breast cancers. This suggests that there is other tumor suppressor gene(s) except TP53 is present at 17p13. Furthermore, the gene responsible for Miller-Dieker syndrome is localized at 17p13. We isolated 37 clones at chromosome band $17 \mathrm{p} 13$ and localized into small intervals using hybrid cell panel, which has microdeletion at $17 \mathrm{p} 13$ (kindly provided from D. $H$. Ledbetter, Ph. D., Baylor College of Medicine, Texas). Then we construct a physical map using pulsed-field gel electrophoresis. The size of fragments is too small enough to link with each others continuously although the range this map cover is nearly lomb wide. Five clones, cCI17-453, -571, $624,-654$ and -703 are localized in Miller-Dieker chromosome region. Using these clones as anchor points, we will isolate candidate genes responsible for tumor progression or MillerDieker syndrome.

\section{B 10}

HUMAN 18TH CHROMOSOME GENE LIBRARY AND GENE MAPPING. Hitoshi NAKASHIMA, Takashi IMAMURA (Dept. Hum.Genet. , National Institute of Genetics, Mishima ) It is estimated that more than 1,000 genes should be on human 18th chromosome. To identify some of these genes we established human-mouse hybrid cells containing human 18th and 18th short arm,respectively. Thimidylate synthetase gene on 18 th short arm worked efficiently as hybrid cell selection marker. Using these cell lines, we tried to obtain 18th chromosome specific DNA and cDNA.

(1) Chromosome 18th specific DNA

Cosmid library (Super Cos 1) was constructed and screened with human total DNA. For some cosmids their locations are determined by FISH.

(2) The identification of expressed gene on chromosome 18th short arm

To survey expressed gene genomic DNA of the hybrid cell containing chromosome 18 th short arm was immobilized on filter and hybridized with human brain cDNA library. Hybridized cDNAs were amplified and constructed new minilibrary. From this library we could obtain 3 clones which hybridized to human DNA as well as hybrid cell DNA. 


\section{B 11}

CONSTRUCTION OF HUMAN CHROMOSOME 21- AND 22pter-q11.2 REGION SPECIFIC COSMID LIBRARIES AND CHARACTERIZATION WITH FLUORESCENCE IN SITU HYBRIDIZATION

Shinsei MINOSHIMA, Yimin WANG, Mizuho TAKATA, Jun KUDOH, Jie SHI and Nobuyoshi SHIMIZU (Dept. Mol. Bíol., Keio Univ. Sch. Med, Tokyo, Japan)

We constructed two cosmid libraries: one is specific to chromosome 21 and the other is specific to the pter-q11.2 region of chromosome 22 . The chromosome 21 specific library was made with flow-sorted chromosomes from B-lymphoblastoid GM130B cells. DNA was extracted and partially digested with MboI using optimized enzyme concentrations. After removal of 5 -phosphate by phosphatase, DNA fragments were ligated to the Supercos1 cosmid vector arms and packaged into lambda phage heads. Twenty-two thousand independent clones, which are 13 times equivalents of chromosomes 21, have been obtained and stored in 96-well plates. These clones were analyzed by FISH using $8327 \mathrm{~L}$ cells carrying a reciprocal translocation $t(4 ; 21)$ (provided by $\mathrm{Dr}$. T. Ikeuchi). Approximately $80 \%$ $(10 / 13)$ clones examined were localized to chromosome 21 and a half of them were mapped distal to the breakpoint (21q22.1-qter). Similarly, a region specific cosmid library was constructed from the marker chromosome of cat eye syndrome cell (CH91-157). More than 100 thousand clones were obtained and storing in 96 -well plates is now in progress. FISH analys is revealed that considerable fractions of these clones retain the sequences derived from the short arm of the marker chromosome. These chromosome and/or region specific cosmid libraries are indispensable tools for human genome analysis.

\section{B 12}

ISOLATION OF POLYMORPHIC MARKERS ON CHROMOSOME 22. Hiroki KURAHASHI $^{1}$, Kenzo AKAGI ${ }^{1}$, Kastu KARAKAWA ${ }^{1}$, Yusuke NAKAMURA ${ }^{2}$, Isamu NISHISHO ${ }^{1}$, Shin-ichiro TAKAI ${ }^{1}$ ( ${ }^{1}$ Dept.Med.Genet.,Biomedical Res.Center, Osaka Univ.Med.Sch., Osaka, ${ }^{2}$ Dept.Biochem.Cancer Inst.,Tokyo)

Genes responsible for NF2, Ewing's sarcoma, or meningioma are thought to be located on human chromosome 22 . Loss of heterozygosity on chromosome $22 \mathrm{q}$ is also reported in colon cancer and pheochromocytoma. In order to identify the genes associated with these tumors, we isolated cosmid markers on chromosome 22. Chinese hamster/human hybrid cell which contains human chromosome 22 was used for source of high molecular weight DNA. After partial digestion with Sau3AI, cosmid library was constructed using pWEX15 cosmid as a cloning vector. Thousand cosmid clones that contain human repetitive sequences were isolated by colony hybridization with radio-labeled total human DNA. Of 200 clones tested, 64 clones showed RFLP. Five clones were VNTR markers. We are mapping these clones by FISH and panel of hybrid cells. These RFLP markers will be used for characterizing molecular abnormalities of those diseases. 


\section{B 13}

A SIMPLE METHOD OF MICRODISSECTION AND MICROCLONING FROM G-BAND SPECIFIC HUMAN CHROMOSOME. Yasunobu YOKOYAMA (Dept. Chromosome, SRL., Inc. Hachioji), Masayuki SASAKI, Toshio OHSHIMA, and Norio SAKURAGAWA(Div. Inher. Metab. Dis., National Institute of Neuroscience, N C N P, Kodaira)

We developed a simple method of microdissection and microcloning. For chromosome prepalation, metaphase cells were harvested by conventional procedure from EB virus-transformed lymphoblastoid cells except for a pre-fixation with ethanol was introduced and spreaded on coverslips. Chromosomes were treated with trypsin and stained by Giemsa. Six dissected fragments from chromosome $22 q$ were directly amplified with two-steps amplification system using modified Degenerate 01 igonucleotide Primed Polymerase Chain Reaction(DOP-PCR). The first step of amplification was performed at a very low annealing temperature and the second amplification was carried out with the primer which has same sequence on 5 'end of the first primer at a hight stringency annealling condition. A smear amplification ranging from 200 to approximately $10 \mathrm{~kb}$ lengh was observed by gel electrophorese. The PCR products derived from chromosone 22q were ascertained by Micro-FISH of Ph-translocation positive sample. PCR products were ligated to EcoR I site of pUC 18 and transfected to JM 109 competent cells and 3000 transformants were obtained.

\section{B 14}

DNA ANALYSIS OF THE Y CHROMOSOME AND YAC LIBRARY SCREENING USING THE Y CHROMOSOME STS (SEQUENCE TAGGED SITE). Yutaka NAKAHORI ${ }^{1}$, Ikumi MATSUSHITA ${ }^{1}$, Taku IHDA ${ }^{1}$, Takashi TAMURA ${ }^{2}$, Terutaka KODAMA 1 , Yasuo NAKAGOME1 (1Dept. Hum. Genet., Tokyo Univ., Tokyo. 2Dept. Clin. Genet., Kyor in Univ. School HIth. Sci., Tokyo)

We have examined DNA samples of patients with a marker chromosome and those with abnormalities of sexual development using Y-chromosome specific probes. Recently, we have determined partial nucleotide sequences of several probes and made the primer sets for PCR to facilitate the analysis of the $Y$ chromosome structure of the patients. Using these sequences as STS (sequence tagged site), we have started screening of the CEPH YAC library. So far, we have been successful to get the YACs in the regions of our interest. 
CLONING AND CHARACTERIZATION OF THE INVERSION BREAKPOINT AT CHROMOSOME 2q35 IN A PATIENT WITH WAARDENBURG SYNDROME TYPE I. Kazuhiro TSUKAMOTO ${ }^{1,2}$, Takaya TOHMA ${ }^{2}$, Tohru OHTA ${ }^{2}$, Kazuhiro YAMAKAWA ${ }^{1}$, Yusuke NAKAMURA ${ }^{1}$, and Norio NIIKAWA ${ }^{2}$

( ${ }^{1}$ Department of Biochemistry, Cancer Institute, ${ }^{2}$ Department of Human Genetics, Nagasaki University School of Medicine)

We report cloning and characterization of an inversion breakpoint of chromosome 2 inv(2)(q35q37.3) observed in a patient with Waardenburg syndrome type I (WSI). Genomic cosmid clones containing the HuP2 gene, which was considered as a candidate for WSI, were isolated from a library constructed from the patient DNA. One of the clones contained the inversion breakpoint and revealed signals at both $2 \mathrm{q} 35$ and $2 \mathrm{q} 37$ by fluorescent in situ hybridization (FISH), indicating disruption of the $\mathrm{HuP2}$ gene by the inversion. Our result further supports that the HuP2 gene is a candidate for Waardenburg syndrome type I and is located at q35.

B 16

TRANSCRIPTIONAL MAP AT THE MENI LOCUS. Tatsushi TODA, Takashi IMAI, Akira TANIGAMI, Tokiko MIWA, Aritoshi IIDA, NAKAMURA (Dept. Biochem, , Cancer Institute, Tokyo)

Multiple endocrine neoplasia type 1 (MEN1) is an autosomal dominant hereditary disorder, which causes hyperplasia or tumors in the pituitary gland, in the parathyroid and in the pancreas. To identify a gene responsible for MENl, we have attempted to construct a transcriptional map at the MENl locus. The gene responsible for MENl is located in nearly $3 \mathrm{cM}$ region at chromosome $1 \mathrm{lql} 3$ by the 1 inkage analysis. Using eight cosmid clones assigned to this region, we isolated nine DNA sequences presumed to be exons, by means of an exon trapping method. Using the DNA sequences, we designed PCR primer sets to generate STSs. We screened several types of CDNA library with PCR products and isolated several CDNA clones, one of which might be a candidate for MENl. We are searching for mutations in MENl families or tumors using these clones as probes. It is important that the DNA sequences identified by this exon trapping method contain no repetitive sequence and are transcribable. 
B 17

Charactarization of YACs surrounding MEN1 loucs.

Aritoshi Iida, Tokiko Miwa, Tatsushi Toda, Kazunori Sudo, Takashi Imai, Yusuke Nakamura.

(Dept. Biochem. Cancer Inst.)

Multiple endocrine neoplasia type 1 (MEN1) is a genetic disorder that consists of neoplasia of neuroendocrine type in the parathyroid glands, in the islets of Langerhans in the pancreas, and in the anterior lobe of the pituitary gland. The gene responsible for MEN1 has been mapped to chromosome 11 by linkage analysis.

To identify gene responsible for MEN1, we have attempted to construct a fine physical map with ordered Yeast artificial chromosome (YAC) clones.

1. The YAC libraries were screened using a PCR - based screening method and a direct colony hybridization procedure with the DNA sequences delivered from the cosmid clones assigned to $11 \mathrm{q} 13$.

2. YAC clones were digested to completion in agarose plugs with tare cutter restriction enzymes; Not I, Nru I, Mlu I and were mapped by pulsed field gel electrophoresis.

3.The end fragments of the insert DNA of some YACs were prepared to use as probes for isolation of linked clones.

Molecular Genetic Analysis of the Breakpoint on Chromosome 22 Involved in NF2 Eiko ARAI ${ }^{1,2}$, Takashi IMAI ${ }^{1}$, Takashi TOKINO ${ }^{1}$ Johji INAZAWA ${ }^{1}$, Tatsuro IKEUCHI ${ }^{2}$ Akira TONOMURA ${ }^{2}$, Yusuke NAKAMURA ${ }^{1}$ ( ${ }^{1}$ Dept. Biochem. Cancer Inst., ${ }^{2}$ Dept. Genet., Med. Inst., Tokyo Med. Dent. Univ.)

NF2 (Neurofibromatosis type 2) is an autosomal dominant genetic disorder characterized by bilateral acoustic neuroma and occasionally associated with meningioma. Although the NF2 gene has been mapped within a $13 \mathrm{cM}$ region between D22Sl and D22S28 DNA markers on chromosome 22 by linkage analysis. We found an NF2 patient with a constitutional balanced translocation $t(4 ; 22)$, the NF2 gene is probably disrupted at the breakpoint. To define the breakpoint, we performed fluorescent in situ hybridization (FISH) with several DNA markers in NF2 region, and mapped the breakpoint within a 2 CM region between D22Sl and LIF genes. Subsequently, a YAC was isolated using LIF as a probe, an extra band was detected by PFGE analysis using one end clone of YAC. Isolating a walking YAC may permit the cloning of the NF2 gene. 


\section{B 19}

CHARACTERIZATION OF 3P14 REGION WHICH CONTAINS THE T(3;8) BREAKPOINT IN FAMILIAL RENAL CELL CARCINOMA. Kazuhiro YAMAKAWA, Shiro YOKOYAMA, Yusuke NAKAMURA (Department of Biochemistry, Cancer Institute, Tokyo)

We previously reported a detailed deletion map of the short arm of chromosome 3 in sporadic renal cell carcinoma, and found that the proximal common region of deletion contained the breakpoint of $(3 ; 8)$ translocation in familial renal cel1 carcinoma (Yamakawa et al, Cancer Res. 51;4707$4711,1991)$. In order to clone the breakpoint, we have analyzed a $3 p 14$ region using fluorescence in-situ hybridization (FISH) and pulsed-field gel electrophoresis (PFGE). We have localized 23 cosmid markers on R-banded prometaphase chromosomes from cells which contain $(3 ; 8)$ translocation; 14 markers were mapped distal to the breakpoint and 9 were mapped proximal. These markers were also analysed on PFGE. of NotI, MluI, NruI, BssHII, EagI digested DNA from cells containing $t(3 ; 8)$. Some markers were localized on the same restriction fragments.

\section{B 20}

RAPID RETRIEVAL OF DESIRED SEQUENCES FROM LONE LINKER PCR-AMPLIFIED CDNA MIXTURE:

APPLICATION TO RECOVERY OF EXPRESSED SEQUENCES FROM CLONED GENOMIC DNA MAPPED TO MOUSE $\mathrm{T} / \mathrm{T}$ COMPLEX

Kuntya Abe ${ }^{1}$, Karen ARTzT ${ }^{2}$ and Ken-ichi Yamamura ${ }^{1}:{ }^{1}$ Inst.of Molec. EMbryol. \& Genetics, Kumamoto Univ. School of Medicine, ${ }^{2}$ Univ. of TeXas at Austin

The $T / t$ complex is a large genomic region located on mouse chromosome 17 , which contains a set of mutations affecting germ cell and early embryos. Molecular genetic analysis of the mutations thus requires construction of cDNA libraries corresponding to early stages of embryogenesis or germ cell development. Such an attempt has been hampered by the difficulty of obtaining sufficient material. Searching for embryo-expressed genes in a large genomic region still remains a cumbersome task, requiring repeated, large-scale screening of libraries with numerous probes derived at every walking step.

To overcome such problems, we developed a technique for cDNA microcloning and a novel method coupling sequence independent-PCR and the biotin-avidin technique for hybrid capture after solution hybridization. This " screening in solution " procedure, combining the efficiency of regular PCR and the versatility of conventional screening, made it possible to enrich for genes of interest directly from cDNA mixtures, skipping large scale screening steps. Here it has been applied to recovering expressed sequences from cloned genomic DNA mapped to the K-region of mouse major histocompatibility complex. 


\section{B 21}

PROGRESS TOWARD THE MOLECULAR CLONING OF THE GENE FOR WERNER 'S SYNDROME Jun NAKURA, Koichi KIHARA, Lin YE, Keiko NAGANO, Tetsuro MIKI, Toshio OGIHARA $($ Dept. Geriat. Med., Osaka Univ. Med. Sch. Osaka) Yusuke NAKAMURA (Div. Biochem., Cancer Inst., Tokyo) Ryo OHTA, Yoshihiro JINNO, Norio NIIKAWA (Dept. Hum. Genet., Nagasaki Univ. Sch. Med., Nagasaki)

Werner's Syndrome (WRN) is a rare autosomal recessive disorder characterized by the appearance of features of premature aging in a young adult. Skin fibroblasts from WRN patients demonstrate slow growth, reduced life span in vitro and mutator phenotype. The genetic defect in WRN is unknown. The incidence of WRN progeny of a firstcousin marriages in. Japan is higher than that in Caucasian countries, because consanguineous marriage is not rare in Japan. We have studied 33 WRN patients from first-cousin matings and examined the status of genetic heterogeneity among WRN patients. A11 of them satisfied the diagnostic criteria made by the research group in Japan. We have been applying homozygosity mapping to search for the WRN locus and confirmed that WRN in on the short arm of chromosome 8, 8p12. A peak lod score of 5.58 at a recombination fraction of 0.03 was obtained with D8S87. We have made a linkage/physical map around the WRN 1ocus using microsatellite genes derived from a microdissection library of $8 \mathrm{p} 12$, cosmid clones of $8 \mathrm{p}$ and YAC clones.

\section{B 22}

DELETIONS AND INSERTIONS DETECTED AMONG JAPANESE IN THE $\alpha$-GLOBIN GENE CLUSTER AND THE RETINOBLASTOMA GENE.

Mieko KODAIRA, Junko KANEKO, Akiko MIURA, and Chiyoko SATOH

(Dep. of Genetics, Radiation Effects Reseach Foundation, Hiroshima)

Mohrenweiser et al. $(1989,1990)$ modified the conventional Souther blot analysis for the detection of DNA variations, such as deletions, insertions and rearrangements (D/I/R). Using this modification, we have been examining 200 Japanese for the detection of the $D / T / R$. This report will present the $D / I / R$ identified among them using two probes, a segment from the $\psi \zeta$-globin gene ( $\psi \zeta$-globin DNA) and the full-length cDNA of the retinoblastoma gene (Rb-cDNA). The $30 \mathrm{~kb}$ region which includes the $\zeta, \psi \zeta$, $\psi \alpha, \alpha 2$ and $\alpha 1$ globin genes in this order can be analyzed with the $\psi \zeta$-globin DNA. Analysis of the 200 individuals with this probe revealed a $3 \mathrm{~kb}$ deletion in the $\alpha 2-\alpha 1$ region of one individual and a $10 \mathrm{~kb}$ deletion in the $\zeta-\psi \zeta$ region of another. Furthermore, an increase of 5-8 kb in one hybridization band corresponding to the region between $\psi \alpha$ and $\alpha 1$ was detected in six individuals. On the other hand, when the $\mathrm{Rb}-\mathrm{cDNA}$ was used as a probe, two individuals who happened to be cousins showed a $300 \mathrm{bp}$ insertion in intron 20 . In order to characterize this inserted sequence, a region which includes the insertion was cloned. Sequence analysis revealed that "CTCTT" tandem repeats were inserted into the tandem array of "CTTT" which flanks the 3' side of the exon 20. 


\section{B 23}

ASSIGNMENT OF HUMAN $\beta$-GALACTOSIDASE-A GENE TO THE SHORT ARM OF CHROMOSOME 3 BY FLUORESCENCE IN SITU HYBRIDIZATION (FISH). Takako TAKANO and Yasuko YAMANOUCHI (Dept. Hygiene, Teikyo Univ., Tokyo)

GM1 gangliosidosis and Morquio B syndrome (MPS IVB) are inherited lysosomal storage disorders associated with deficiency of $\beta$-galactosidase-A ( $\beta$ GALA) activity. Phenotypic variability among $\beta$ GALA mutants depends on the mutation site and the residual activity of the mutant enzyme. Both disorders are transmitted as an autosomal recessive trait.

Recombinant plasmid containing the biotinylated cDNA ( $2.4 \mathrm{~kb}$ insert) encoding human $\beta$ GALA was used to localize the enzyme by fluorescence in situ hybridization (FISH). Normal human male R-banded prometaphase chromosomes were prepared by thymidine-synchronization followed by BrdU incorporation. For biotin detection, the slides were incubated with fluorescein-avidin in addition to the amplification of signals and were stained with propidium iodine.

We detected twin spot fluorescent signals on both sister chromatids of 3p21.33. The human BGALA gene was assigned to band $3 \mathrm{p} 21.33$.

\section{B 24}

DIFFERENTIAL STAINING OF HUMAN CHROMOSOMES AND FLUORESCENCE IN SITU HYBRIDIZATION. Momoki HIRAI. Yumiko SUUTOU and Michiko KaNo (Dept. Anthropol., Fac. Sci., Univ. Tokyo, Tokyo)

The direct R-banding in situ hybridization method developed by Takahashi et a1.(1991) is a powerful tool for the precise localization of cloned human genes and DNA fragments. However, this method is not suitable for G-banding fluorescence in situ hybridization. The chromosomal regions which did and did not incorporate bromodeoxyuridine during the early $S$ phase of the cell cycle were not differentially stained after the standard chromosomal DNA denaturation step. In the present study, we developed improved techniques for detecting G-bands and in situ hybridization signals. The formaldehyde pretreatment and chromosomal alkaline denaturation are our modifications of the standard protocol. Signal detection using this method was less efficient than that obtained with direct R-banding in situ hybridization. Nevertheless, we expect this method will have many uses. For instance, combining it with $R$-banding in situ hybridization may enable us to localize probes which hybridize with the boundary regions of adjacent $R$ - and $G$ - bands precisely. 
B 25

DETECTION OF CHROMOSOHAL ANEUSOHY BY FISH TECHNIQUE -ACCURACY AND CHARACTERISTIC- Takazuni KOZAKI, Hideyuki UMII and Takao AYA(Dept. of Chromosome Analysis, SRL, Inc.,Tokyo)

This is the investigation for estimation of the accuracy and characteristics of chromosomal aneusony by FISH technique. Norwal and aneusomy cells were examined by using different kinds of centronere specific DNA probes. Afterward the detection rates were calculated by the count of the number of fluorescence signals per 1000 interphase nuclei according to the standard criterion.The detection rates obtained in interphase nuclei were 1$) \$ 13$ and \$21 chromosomes: normal cells(4 signals) $58.4 \%, 21$ trisomy (5 signals) $49.5 \%$ 2) 18 chromosones: normal cells(2 signals)91.5\%,18 trisony (3 signals)83.0\% 3)X chromosones: $X$ monosomy (1 signal)96.2\%, normal female(2 signals)94.3\%, $X$ trisony ( 3 signals) 77.2\% 4)Y chromosomes:noral male(1 signal)95.1\%,Y disony (2 signals)62.6\%. Although the sensitivity was different within probes,it is sufficiently applicable to use these probes for tile investigation of numerical chromosome aberrations.

B 26

ANEUPLOIDY RATE DETECTION IN NORMAL HUMAN SPERM USING FLUORESCENCE IN SITU HYBRIDIZATION (FISH). Hu He Etsuji OKAMOTO, TOMOVa MIZUNOE, Yoshiharu NAKAOKA, Satoshi HAYASHI and Koso OHAMA (Dept. Obstet. and Gynecol., Hiroshima Univ. Sch. of Med., Hiroshima)

Sperm aneuploidy study has been performed in six normal young males using FISH. To detect sperm numerical chromosomal aberration, alpha satellite DNA probes D1Z5, D17Z1, D18Z1, DXZ1 and DYZ3 were used for chromosomes No.1, 17, 18, $X$ and $Y$ respectively. The frequency of hyperhaploid rate of sperm with more than one hybridization spots, for chromosomes No.I $17,18, X$ and $Y$ were $0.64 \%, 0.66 \%, 0.60 \%, 0.28 \%$ and $0.27 \%$, respectively. To estimate the diploidy and disomic rate, we used D21Z1/D13Z1 and the mixture of D17Z1 and D18Z1. The average rates of disomy was $0.365 \%$ for $17 / 18,0.352 \%$ for $21 / 13$, and the diploidy rate was $0.258 \%$ for $21 / 13,0.266 \%$ for $17 / 18$. We suggest that all human sperm chromosomes, including sex chromosomes, have the same frequency of nondisjunction. The sperm hyperhaploidy rate in the present study was about $8.5 \%$. It was higher than the sperm aneuploidy studies in which using chromosomal karyotype analysis after human sperm penetration of hamster egg. In the karyotype studies the frequency of numerical abnormality was about $0.7 \%-5 \%$. The high sperm hyperhaploidy rate in our study reflected abnormalities of the whole sperm including those fertile and infertile sperm. 


\section{B 27}

INTERSTITIAL DELETION OF THE LONG ARM OF CHROMOSOME 11 :AR ASCERTAINMENT BY FLUORESCENCE IN SITU HYBRIDIZATION.

Mitsuo MASUNO ${ }^{1}$, Tada-aki HORI ${ }^{2}$, Akihiro WAKAZONO ${ }^{1}$, Seiji YAMAGUCHI ${ }^{1}$, Tadao ORII ${ }^{1}{ }^{1}$ Dept. Pediatr., Gifu Univ. School Med., Gifu; ${ }^{2}$ Div. Genet., Natl. Inst. Radiol. Sci., Chiba)

A 12-month-old female infant with developmental delay, growth retardation, and dysmorphic features including dolichocephaly, telecanthus, ptosis, flat nasal bridge, anteverted nares, high-arched palate, carp-shaped mouth, micro-retrognathia, and low-set and posteriorly rotated ears was found to have an interstitial deletion of chromosome 11 involving about two-thirds of bands 11q14-q22 using GTG high resolution chromosome banding technique. The interstitial deletion was examined by a direct mapping system combined with fluorescence in situ suppression hybridization and replicated prometaphase R-bands (Takahashi et al., 1991) using cosmid DNA markers mapped on the long arm of chromosome 11 (kindly provided by Dr. Y. Nakamura). Three cosmid clones mapped on 11q14.1-q22.1 regions were not hybridized to the del(11) chromosome, while all the other DNA markers mapped on 11q13.1q14.1 and 11q22.3-q24.3 regions gave hybridization signals on the del(11) chromosome. Cytogenetic analysis after R-banding confirmed an apparent deletion of 11q14-q22, but containing a small R-negative band, a part of 11q22.3 and/or 11q14.1, in the middle part of del(11) chromosome. The karyotype thus was determined to be $46, \mathrm{xx}$, del (11) (q14.1q22.3).

\section{B 28}

A case of Turner syndrome suspected with $45, X / 46, X, d i c(Y)$ mosaicism. Ki ichi SHIMIZU, Toshihiro GOTO(Shionogi Biomed. Lab., Osaka), Yasuo NAKAGONE(Dept. Hum.Genet., Tokyo Univ.Tokyo), Ke isuke WADA(Dept.Obstet., Gifu Univ.Gifu)

Chromosome analysis of a patient which was suspected as Turner syndrome,revealed $45, X / 46, X,+$ mar mosa icism. For the identify of this marker chromosome we have studied the some banding techniques, ONA analys is by PCR and Fluorescence in situ hybridization(FISH). The patient, a 33-year-old female, was referred to us because of primary amenorrhea. Physical examination revealed Turner syndrome like, a height of $140 \mathrm{~cm}$ and Uterus was present but atrophied.

An analysis was carried out using peripheral blood leukocytes. As the methods, we used Chromosome analysis (G-,Q- and C-banding), DNA analys is by PCR with 8 loci on Y chromosome ( PABY,SRY,AMGL, DYZ3, DYS139,DYS132, DYS1, DYZ1), and FISH with $\alpha$-satellite Probe of $Y$ chromosome(DVZ3:oncor). Consequently, the patient was positive for all the loci except for OYZ1. Also, as this marker chromosome was detected two signals of DVZ3 by FISH, it was identified with nonfluorescent dicentric $Y$ chromosome. Therefore, we determined that Karyotype of the patient was $45, X / 46, X$,dic $(Y)$ (pter to q11.23::q11.23 to pter).

We are interested in this symptom upon thinking of the sex differentiation, as SRY loci has been positive and the phenotype was female. 


\begin{abstract}
ECOGENETIC STUDY OF N-ACETYLATION POLYMORPHISM
I. ASSOCIATION WITH COLORECTAL CANCER. KEN ji SHIBUTA, Tadasu NAKASHIMA, Masako ABE, Masami MASHIMO, and Tomokazu SUZUKI. (Dept. of Clin. Genet., Med. Inst. of Bioregulation, Kyushu Univ., Beppu)

N-acetylation polymorphism has been documented as a representative of pharmacogenetic traits, and implicated ecogenetically in the susceptibility to cancer and other diseases. Recently we developed a rapid and simple genotyping method by PCR based RFLP to predicted phenotypes. In the present study, we analyzed the acetylator phenotype in 234 patients with colorectal cancer and 54 normal control subjects. There was a significant difference in the distribution of acetylator phenotypes between the groups $\left(\mathrm{x}^{2}=16.19, \mathrm{P}<0.001\right)$. In addition, a significantly higher proportion of slow acetylators was observed in the patient group under 63 years of age at onset, in rectal cancer group or in well differentiated cancer group as compared with the control group. The data suggest that $\mathrm{N}$-acetylation polymorphism may play a role in susceptibility to colorectal cancer and that slow acetylator individuals may be at higher risk to arylamine induced colorectal cancer.
\end{abstract}

\title{
B 30
}

CYTOGENETIC STUDIES ON THE FIBROBLASTS IMMORTALIZED WITH SV40ori-. II. Fumiko SAIT0 ${ }^{1}$, Shin-ichiro IMAI ${ }^{2}$, Tatsuro IKEUCHI ${ }^{1}$, Kaoru SEGAWA ${ }^{2}$, Akira TONOMURA ${ }^{1}$, Toshiya TAKANO ${ }^{2}$ ( ${ }^{1}$ Dept. Cytogenet. Tokyo Med. Dent. Univ., Tokyo, ${ }^{2}$ Dept. Microbiol., Keio Univ. School Med., Tokyo)

Although normal human diploid fibroblasts are hardly immortalized in in vitro systems, the SV40 transformants exhibit unlimited proliferative potential on rare occasions. Chromosome studies at earlier stages of immortalization are necessary for better understanding of the role of mutational events during immortalization in vitro. In the series of our study, we have used two cell colonies (HuSI-L12 and -L23) transformed from human fibroblasts with an SV40 ori-encoding large $T$ antigen. Eight immortalized derivative clones were isolated from the two transformants. Among these, five immortal clones were found to be tri- or tetraploid and three were hypodiploid (modes: 40,41,43) with some structural chromosome changes. Detailed chromosome analys is in the hypodiploid immortal clones, which can be very rarely obtained in general, revealed that total or partial losses of chromosomes 5 and 10 were common to all the cell clones. We suggest that loss of specific segment(s) of these chromosomes may represent one of the mutational events responsible for immortalization of SV40 transformed fibroblasts 
B 31

DETAILED DELETION MAP OF HUMAN CHROMOSOME 6q IN OVARIAN CANCER. Susumu SAITO ( Dept. Biochem., Cancer Inst., Tokyo, SRL, Tokyo), Hiroko SAITOO (Dept. Biochem., Cancer Inst., Tokyo), Sumiko KOI (Dept. Gynecol., Cancer Inst., Tokyo), Satoru SAGAE Ryuichi KUDO (Dept. Obst. Gynecol., Sapporo Med. Coll., Hokkaido), Junko SAITO Ki-ichiro NODA (Dept. Obst. Gynecol., Kinki Univ. Sch. Med., Osaka) and Yusuke NAKAMURA (dept. Biochem., Cancer Inst., Tokyo)

To define a small region on chromosome $6 \mathrm{q}$ containing a putative tumor suppressor gene for ovarian cancer, we examined loss of heterozygosity $(\mathrm{LOH})$ in 70 ovarian tumors of three histological types with nine RFLP markers located at 6q2427. Among 33 cancers of serous type that were informative at one or more loci, 17 showed allelic loss at a few or all loci examined, whereas only one of 15 mucinous-type tumors and two of 12 clear-cell tumor revealed LOH. Frequent losses were observed between loci defined by CI6-119 (D6S195) at 6q26 and CI6-49 (D6S161) at 6q27. A detailed deletion map indicated a commonly deleted region between loci defined by CI6-111 (D6S193) and CI6-24 (D6S149); these two markers are estimated to be $1.9 \mathrm{cM}$ apart on the basis of linkage analysis. Our results further define a region containing a tumor suppressor gene involved in ovarian carcinoma within an approximately 2-megabase-long segment of chromosome $6 \mathrm{q}$.

\section{B 32}

AGE-SPECIFIC, ORGAN-DEPENDENT CARCINOGENESIS IN NEUROFIBROMATOSIS TYPE 1 Masako TANIMURA, Ichiro MATSUI (Dept. Child Ecology, Natl. Children's Medical Research Center), Noboru KOBAYASHI (Nat1. Children's Hospita1)

To assess the risk for malignancy in adults in neurofibromatosis type 1 (NF1), we reviewed the Annual of the Pathological Autopsy Cases in Japan from 1958 to 1988.

Among 801,246 autopsied cases, 331 cases of malignancy with NF1 were found. The rate of NF1 was significantly higher in malignant schwannoma, glioma (ependymoma, astrocytoma, glioblastoma multiforme, etc.), pheochromocytoma, and also in rhabdomyosarcoma (extremity), leiomyosarcoma (jejunum etc.) and malignant melanoma, than in all malignancies (0.116\%), and significantly lower in stomach and/or liver cancer. Some childhood malignancies increased in NF1 such as rhabdomyosarcoma of urogenital organs and myelogenous leukemia were not observed in NFI adults. Compared with malignancies without NF1, the age distribution at death was younger in NF1 patients with malignant schwannoma, glioma, malignant pheochromocytoma, malignant melanoma, rhabdomyosarcoma, leiomyosarcoma and small intestinal cancer, all of which showed a significant risk of malignancy in NF1. Moreover, NF1 with malignancy, which was not increased in NF1, showed a similar age distribution at death to the general population.

These results suggest that the NF1 gene increases the risk of malignancy at a specific age in certain organs and accelerates the onset in adults. 


\section{B 33}

Neurofibromatosis type 1 gene produces four types of transcript by alternative splicing in the region coding for GTPase activating protein-related domain. Akio MANTANI, Shyoji WAKASUGI, Ken-ichi YAMAMURA (Institute of Molecular Embryology and Genetics, Kumamoto University School of Medicine, Kumamoto)

Type 1 neurofibromatosis (NF1) gene have been recently identified by positional cloning and sequence analysis has shown homology to the GTPase activating protein (GAP) family. The previous report revealed two types of NF1-GAP related domain (NF1-GRD) transcript which appear to be generated by an alternative splicing mechanism. Type 1 transcript was expressed predominantly in undifferential neural cells, whereas type 2 in differential neural cells. To analyze the structure and expression of NF1-GRD and produce a model mouse for this disease by gene targeting, we analyzed mouse NF1-GRD. We cloned four types of mouse NF1-GRD cDNA which were generated by alternative splicing. The expression pattern of type1-type4 NF1-GRD mRNA is tissue-specific. This together with other results suggest that alternative splicing of NF1-GRD has some important biological significance in cell differentiation.

\section{B 34}

MOLECULAR ANALYSIS OF 2 JAPANESE DENYS-DRASH SYNDROME. Masahiko TSUDA, Takeshi SAKIYAMA, Teruo KITAGAWA (Dept. Pediatr., Nihon Univ., Tokyo), Shuichiro WATANABE, Takeshi WATANABE, Shori TARAHASHI (Div. Nephrology, Shizuoka Children's Hospital, Shizuoka), Hiroshi KAWAGUCHI and Katsumi ITO (Dept. Pediatr. Nephrology, Kidney Center, Tokyo Women's Univ., Tokyo)

Two cases of Japanese Denys-Drash syndrome were analyzed by molecular aproach. PCR was performed to amplify both exon 8 and 9 of Wilms tumor suppressor gene (WT1). SSCP analysis did not reveal mobility shift in exon 8 in both cases. However direct suquencing of exon 9 in both cases identified point mutation at one allele. Case 1 had $\mathrm{C}$ to $\mathrm{T}$ change resulted in 394Arg to Trp mutation which was the most common mutation reported by Pellitier et al. This $\mathrm{C}$ to $\mathrm{T}$ change abolished the restriction enzyme Msp Irecognition site and was easily detected by PCR and Msp I digestion. Normal control showed complete digestion of PCR product of exon 9 by Msp I and case 1 showed heterozygosity. Case 2 had $\mathrm{T}$ to $\mathrm{C}$ change resulted 398Leu to Pro mutation at one allele. This mutation was the newly identified mutation. Our results showed mutations of Denys-Drash syndrome were heterogenous and exon 9 was the hot spot for mutations. 


\section{B 35}

B-CELL GROWTH FACTOR (BCGF)-AIDED CHROMOSOME ANALYSIS IN B-CELL MALIGNANCIES. IkUo SATO (Sapporo Patho1. Test. Center), Chikara MIKUNI (Natl. Sapporo Hosp.) and Syuiti ABE (Chromosome Res. Unit, Fac. Sci., Hokkaido Univ., Sapporo)

A combination of BCGF and lipopolysaccharide (LPS), rather than LPS alone, was found to increase the metaphase yields in cultured peripheral blood, bone marrow, or lymph node from 30 B-cell malignancies including 13 chronic lymphocytic leukemia (CLL) and 17 non-Hodgkin's 1ymphoma (NHL) with or without leukemic phase. Among them, 19 cases (5 CLL and 14. NHL) showed clonal chromosome abnormalities, and 11 (8 CLL and 3 NHL) had only normal karyotypes or concurrent non-clonal abnormalities in a few cells. The translocations involving the long arm of chromosome 14, $14 q 32$, were predominant in NHL (11 of 14 cases) but not observed in CLL. The most frequent $14 q 32$ abnormality was $t(11 ; 14)(q 13 ; q 32)$ or its derivative, der $(14) t(11 ; 14)$, which was found in 6 cases with leukemic phase and associated with invasion of leukemic cells in various tissues and organs. The trisomy 12 was observed in 3 CLL but not in NHL. The present findings suggest that BCGF is useful for chromosome analys is in chronic B-cell malignancies, and that it may provide a better correlation of chromosome data with clinico-pathologic findings in such diseases.

\section{B 36}

CYTOGENIC AND MOLECULAR FINDINGS IN LEUKEMIA AND PRELEUKEMTA OFPATIENTS WITH FANCONI ANEMIA. Shinsuke NINOMIYA, Kouji NARAHARA, Kazushiro TSUJI, Yuji YOKOYAMA, Tsunerori MATSUBARA, Yoshiki SEINO(Dept. Pediat., Okayama University Medical School, okayama), Yoshiharu WAKITA, and kiyoshi KIKKAWA (Kouchi Pref. Cent. Hosp.)

Fanconi anemia (FA) is an autosomal recessive disorder, characterized by progressive pancytopenia, diverse congenital abnormalities, and increased predisposition to a particular of malignancy. We studied chromosomes of bone marrow in three FA patients who developed acute myeloblastic leukemia or myelodysplastic syndrome. The karyotype was $47, \mathrm{X},-\mathrm{Y},+\operatorname{del}(\mathrm{Y})(\mathrm{q} 12)$, $+\operatorname{de} 1(\mathrm{Y})(\mathrm{q} 12),-7, \operatorname{der}(7) \mathrm{t}(1 ; 7)(\mathrm{p} 11 ; \mathrm{q} 11), \operatorname{del}(3)(\mathrm{q} 21)$ for Case 1 ; $46, X Y,-14,+\operatorname{der}(14) \mathrm{t}(1 ; 14)(q 11 ; \mathrm{p} 11), \operatorname{dup}(3)(\mathrm{q} 21-\mathrm{q} 25)$ for Case 2 ; and $47, X X,+i(1 q), t(11 ; 15)(q 23 ; p 12)$ for Case 3 . In Case 3 we investigated SPTAl locus on $1 q 21$ in the bone marrow and somatic cell, using southern hybridization. The somatic cells had heterozygous bands, while bone marrow showed loss of heterozygosity. It seems likely that $1 \mathrm{q}$ duplication is the most important chromosome abnormality associated with leukemia and preleukemia in FA patients. The molecular finding in Case 3 suggests that loss of heterozygosity on some $1 \mathrm{q}$ region may be related to the occurence of malignancy in FA. 
B 37

LOSS OF A CHROMOSOME 17p AND p53 GENE MUTATIONS IN THE PROGRESSION OF CHRONIC MYELOGENOUS LEUKEMIA. Hiroyuki NAKAI, Shinichi MISAWA, Masafumi TANIWAKI, Shigeo HORIIKE, Shouhei YOKOTA, Teruyuki TAKASHIMA, Taku SERIU, Yuko KUZUYAMA, Kouichi HIRAKAWA, Kei KASHIMA (3rd. Dept. of Internal Medicine, Kyoto Prefectural Univ. of Medicine, Tokyo), Hitoshi NAKAGAWA, Hiroshi FUJII (Internal Medicine, Kyoto 1st Red Cross Hosp., Kyoto) and Kanji ISHIZAKI (Radiation Biology Center, Kyoto Univ., Kyoto)

We examined chromosome aberrations and p53 gene mutations in 118 samples from 92 patients with chronic myelogenous leukemia (CML) in various clinical phases. Single-strand conformation polymorphism (SSCP) analysis and DNA sequencing revealed no p53 gene mutation in 80 chronic phase samples, while one of 7 accelerated phase (AP) samples and 5 of 31 blast crisis (BC) samples showed mutations. Chromosome analysis disclosed loss of a chromosome $17 \mathrm{p}$ in 10 of $31 \mathrm{BC}$ samples through the formation of isochromosome $17 \mathrm{q}$ or unbalanced translocations. Among the 6 samples with p53 gene mutations, the AP sample and 4 myeloid BC samples carried loss of a 17p, while only one lymphoid BC sample showed normal chromosome 17 homologues. Thus, p53 gene mutations may contribute to the progression of CML and appear to be closely associated with myeloid crisis with loss of a $17 \mathrm{p}$.

\section{B 38}

ANALYSIS OF T CELL RECEPTOR (TCR) $\delta$ CHAIN GENE REARRANGEMENT IN CHILDHOOD ALL AND NHL. Taku SERIU, Shouhei YOKOTA, Shinichi MISAWA, Ko ichi HIRAKAWA, Yuko RUZUYAMA, Hiroyuki NAKAI, Teruyuki TAKASHIMA, Shigeo HORIIKE, Masafumi TANIWAKI, Kei KASHIMA (Dept. 3rd. Int. Med., Kyoto Pref. Univ. Med.), Shoichi KOIZUMI (Dept. Pediat., Kanazawa Univ.), Yoichi TAKAUE (Dept. Pediat., Tokushima Univ.), Susumu KaWAI, and Takeo FuJIMoto(Dept. Pediat., Aichi Med. Univ., CCLSG)

We examined the rearrangement of the TCR $\delta$ chain gene in 76 children with acute lymphoblastic leukemia (ALL) or non-Hodgkin lymphoma (NHL) in relation to immunological phenotypes of the tumor cells. Southern blot analysis and PCR showed 53 of 68 B-lineage ALL, all of 2 undifferentiated ALL, and all of $6 \mathrm{~T}-1$ ineage ALL or NHL had one or more rearranged band or deletion of J $\delta 1$ locus. 42 of 43 non deletional $\delta$ locus involvement in B-lineage ALL had a V $\delta 2-D \delta 3$ rearrangement of at least one allele. This type was not found in undifferentiated or T-lineage leukemia. 2 undifferentiated ALL showed a $D \delta 1 / 2$ $-D \delta 3$ rearrangement, that is earlier stage of it. A complete V $\delta 2-D-$ J $\delta 1$ rearrangement was found in 3 of $6 \mathrm{~T}$-lineage ALL or NHL, and this type was specific for $\mathrm{T}-\mathrm{lineage}$ tumors. 
B 39

MOLECULAR ANALYSIS OF CHROMOSOME ABNORMALITIES FOUND IN PATIENTS WITH ATAXIA TELANGIECTASIA. Masaharu ISOBE, Fuminori YAMAGISHI, Harubumi Muto, Yoshinori KUMURA, Zen-ichi OGITA (Dept. of Patho-biochem., Toyama Med. \& Pharma. Univ, Toyama) and Tsutomu OH-ISHI, Yoshimitsu FUKUSHIMA (Saitama Children's Medical Center, Saitama)

Chromosome abnormalities involved in chromosome 14 at band q32.1 such as $t(7 ; 14)(q 3 ; q 32)$ and $t(14 ; 14)(q 11 ; q 32)$ have been considered to be important for the pathogenesis of T-cell malignancy which is frequently found in AT patients. We have cloned breakpoints of these translocations using probes from $\mathrm{T}$-cell receptor loci and named this 14q32.1 region tcl-1 locus. By chromosome walking, we have cloned the region of more than $300 \mathrm{~kb}$ around tcl-1 locus and found all the $t(7 ; 14)$ and $t(14 ; 14)$ translocations so far described occurred within this region. We have performed fluorescent in situ hybridization using probes from $14 q 32$ region on two cases of $t(14 ; 14)$ translocations and one case of $t(7 ; 14)$ translocation. In all cases we found the inversion duplication event between the region telomeric to immunogloblin $\mathrm{J}$ region and tcl-1 locus. Interestingly we found further inversion duplication event around tcl-1 locus in a t $(7 ; 14)$ translocation which derived from a T-cell leukemia of a patient with AT.

B 40

MOLECULAR APPROACH TO AN INHERITED DISEASE BY USE OF MUTANT MICE GENERATED BY GENE TARGETING. Shuichiro MAEDA (Dept. Biochem., Kumamoto Univ. Sch. Med., Kumamoto), Seiji NISHIGUCHI, Kyoji HORIE and Kazunori SHIMADA (Dept. Med. Genet., Res. Inst. Microbial Diseases, Osaka Univ., Usakal

Familial amyloidotic polyneuropathy (FAP) is an autosomal dominantly inherited disease that primarily affects peripheral and autonomic nervous systems. We demonstrated that the main cause of FAP is the presence of a point mutation in the transthyretin (ttr) gene. TTR is a serum protein which is considered to play an important role in the plasma transport of thyroid hormones and retinol. TTR is also known to bind other ligands such as dioxins and halogenated biphenyls. To elucidate the physiological function of TTR in development or in the life of the adult organism, we used gene targeting techniques to generate a null mutation at the mouse ttr locus. The resultant mutant mice appear to be phenotypically normat and viable. However, plasma levels of thyroid hormone (thyroxin) and retinol are significantly depressed in the mutant mice. The mutant mice will be useful for investigating the transport and metabolism of these metabolites. They will also be used as recipients of the human mutant $t$ tr genes associated with FAP. These transgenic mice will be useful for studying the function of the TTR variants and their role in the pathogenesis of FAP. 


\section{B 41}

AMYLOIDOGENIC PROCESS IN TRANSGENIC MOUSE MODEL FOR AUTOSOMAL DOMINANT DISEASE. Ken-ichi YAMAMURA (Inst. Mol. Embryol. Genet., Kumamoto Uiv. Sch. Med.), Fumi TASHIRO (Dept. Disease-related Gene regulation Research, Faculty Med., Univ. Tokyo), Shuichiro MAEDA (Dept. Biochem., Kumamoto Univ. Sch. Med.) and Kazunori SHIMADA (Inst. Microb. Disease, Osaka Univ.)

Familial amyloidotic polyneuropathy (FAP) is a typical autosomal dominant disorder characterized by the extracellular deposition of amyloid fibrils and by prominent peripheral and autonomic nerve involvement. The amyloid protein is mainly composed of transthyretin (TTR; a protein formerly known as prealbumin) with a substitution of methionine for valine at position 30 (hMet30) in most of Japanese cases. To elucidate the pathological process of this disease development, we have produced transgenic mouse. The genes introduced are hMet30 gene carrying either its own promoter (0.6-hMet30) or mouse metallothionein promoter (MthMet30), and human serum amyloid $P$ component (hSAP) gene. From analyses of these trarisgenic mice we comfirmed the amyloid deposition and its progression with aging in transgenic mice. We also found that the earliest age of amyloid deposition was at around 6 months. This result clearly suggests that the amyloid deposition itself starts later in life, and that several factors can affect this initiation of amyloid deposition. Other findings obtained from analyses on single or double (hMet30 $\mathrm{hSAP}$ ) transgenic mice are as follows : (I) the tetramers composed of mostly hMet30 are important for deposition as amyloid due to physicochemical property of this molecule, (2) hSAP does not affect the initiation, progression and tissue distribution of amyloid deposition, (3) microenvironment in each tissue, such as blood flow and loose tissue structure, can affect greatly the amount of amyloid deposition.

B 42

A gene trap in murine embryonic stem (ES) cells for the isolation of novel genes. Hitoshi NIWA, Mako MORIYAMA, Kouichiro ABE, Kuniya ABE, Ken-ichi YAMAMURA (Institute of Molecular Embryology and Genetics, Kumamoto University School of Medicine)

A gene trap in embryonic stem (ES) cells is a powerful method because we can isolate numerous unknown genes functioning in the early stages of development and morphogenesis, examine the expression pattern of the endogenous gene, and obtain insertional mutant mice. We constructed new trap vectors and carried out the gene trap experiment using the ES-D3 cells. In this experiment, the cell lines established from the clones expressing the reporter genes in undifferentiated states were injected into C57BL/6 blastocysts and chimeric mice were produced. Nine out of 12 chimeric mice showed germline transmission. These offspring are now breeding to homozygosity to test whether any phenotype may appear or not. For efficient gene trap, we should prescreen clones of interests and reduce the amount of work required for generation of chimeric mice using every ES clones. The ES cells spontaneously start to differentiate in suspension culture in the absence of the leukemia inhibitory factor (LIF) and form the embryoid body resembling early postimplantation embryos. At least the visceral endoderm, the primitive ectoderm and the mesodermal precursors are differentiated in this system, so that we can analyze the genes involved in the differentiation of these cell lineages. 


\section{B 43}

AN ATTEMPT OF GENE TRAP BY MICROINJECTING PROMOTERLESS NEO GENE INTO FERTILIZED EGGS. Shoji WAKASUGI, Akio MANTANI, Satoshi SUGAI, Shigemi KIMURA, Tadashi KANAME and Ken-ichi YAMAMURA (Institute of Molecular Embryology and Genetics, Kumamoto University School of medicine, Kumamoto, 862, Japan)

We formerly reported that the G418 selection can be done during the preimplantation stage of mouse development. Then, promoterless neo genes were injected into the mouse eggs to examine whether mouse endogenous gene can be trapped. We injected this gene into 680 eggs and only one blastocyst was survived after culture from two-cell stage embryos in the presence of $150 \mu \mathrm{g} / \mathrm{ml}$ of $\mathrm{G} 418$. However, no pup was born when this blastocyst was transferred into uteri of foster mother. Promoterless neo gene containing the polyoma enhancer at its $3^{\prime}$ end were also injected into 1910 eggs and 229 blastocysts were survived after culture from two-cell stage embryos in the presence of $150 \mu \mathrm{g} / \mathrm{ml}$ of G418. Fifteen pups were born, fourteen pups were transgenic. These results indicated that gene trap can occur at preimplantation stage embryo leading to the expression of neo gene.

\section{B 44}

IDENTIFICATION OF HUMAN CHROMOSOME THAT COMPLEMENTS RADIOSENSITIVITY IN CELL LINES DERIVED FROM SCID MOUSE. Yuiko NAGATA, Akihiro KURIMASA and Mitsuo OSHIMURA (Dept. of Mol. \& Cell Genet., Sch. of Life Sci., Facuity of Med., Tottori Univ., Yonago)

The mouse scid (severe combined immunodeficiency) mutation impairs the recombination of $V(D) J$ coding joint in the immunoglobulin and T-ce 1 receptor genes and also induces hypersensitivity to ionizing radiation of not only lymphoid cells but also other tissues. An attempt was made to identify the human chromosome that restores radiosensitivity in cell lines (SCVA) derived from SCID mouse by transferring human chromosome via microce11-fusion. First, a mixture of microcells isolated from mouse A9 cells containing 8 different human chromosomes, were fused with SCVA cel1s, and irradiated with ${ }^{60}$ Co $\gamma$-ray. Most surviving clones contained a human chromosome 8 . The surviving fraction of \#8-microce 11-hybrids at 6 Gy were about 10 times higher than those of parental cells. After irradiation (1Gy) at G2 phase, the frequency of the chromatid-type aberrations in microcel1-hybrids with the transferred chromosome 8 were significantly lower than that of parental cells. These findings suggest that hypersensitivity to ionizing radiation in cel1 lines derived from SCID mouse is due to a deficiency in repairing DNA double-strand breaks, and that a human gene which complements mouse scid mutation is located on chromosome 8. 
ROLE OF HHC MOLECULES EXPRESSED ON THYMIC EPITHEIIAL CELLS ON T CELL REPERTOIRE SELECTION. Yoshinort FUKUI, Ken YAMAYOTO, YukIo ESAKI, Akinor I KIMURA, Takehiko SASAZUKI (Dept. Gent., Med. Inst. Bioreg., Kyushu Univ., Fukuoka)

The discrimination between the self and non-self occurs in the thymus through positive and negative selection of $T$ cell repertoire as a consequence of interaction of self major histocompatibility complex (MHC). However, it remains unclear which cell in the thymus is responsible for these process. To evaluate the role of thymic epithelial cells (TEC) on $T$ cell repertoire selection, we compared HLADRA transgenic mice (TGM, line 30) expressing the DRA gene exclusively in TEC with another HLA-DRA TGM (1ine 24) expressing the DRA gene in TEC and bone marrow-derived cells (BDC) in some immunological phenomena. The fate of $D R \alpha E \beta^{b}$-restricted $T$ cells was followed by breeding these TGM with TGM expressing $\alpha \beta \mathrm{T}$ cell receptor (TCR) reactive to foreign antigen/DR $\alpha \mathrm{E} \beta^{\mathrm{b}}$ complex. $\mathrm{CD} 4^{+} \mathrm{CD} 8^{-} \alpha \beta^{\mathrm{h}}$ thymocytes emerged in 24 a $\beta$ double TGM, but not in $30 \alpha \beta$ double TGM. TCR V $\beta 5^{+}$and $V \beta 11^{+} \mathrm{T}$ cells reactive to self-superantigen/DRaE $\beta^{b}$ complex were eliminated in the line 30 at a comparable level in the line 24 . CD4 $4^{+} \mathrm{T}$ cells from the line 30 as well as those from the line 24 were tolerant to $D R \alpha$-derived peptide/I-A complex even in the presence of exogenous $1 \mathrm{~L}-2$. Therefore, in contrast to the current view, our observation suggest that BDC expressing relevant $\mathrm{MHC}$ molecules are required for positive selection and that TEC are potent for negative selection of $\mathrm{T}$ cell repertoire reactive not only for self-superantigen/MHC complex but also to processed self-peptide embeded in MHC molecules.

\section{B 46}

EXPRESSION OF DR $\alpha E \beta^{b}$ MOLECULE AND DR $\alpha$ DERIVED PEPTIDE/I- $\mathrm{A}^{\mathrm{b}}$ COMPLEX IN THREE LINES OF HLA-DRA TRANSGENIC MICE KEN YAMAMOTO, YOSHINORI FUKUI, YUKIO ESAKI, KAZUAKI YAMANE, KATSUIKU HIROKAWA*, and TAKEHIKO SASAZUKI (Dept. Genet., Míed. Inst. Bioreg., Kyushu Univ., Fukuoka, *Dept. Pathol., Tokyo Metropol. Inst. Gerontol., Tokyo)

MHC class II molecules play a crucial role in the immunological processes of $\mathrm{T}$ cell education in the thymus and antigen presentation to $T$ cells in periphery. These molecules are expressed on immunocompetent cells such as B cells (B), macrophages, dendritic cells (DC) and thymic epithelial cells (TEC). However, immunological functions of MHC molecules expressed on each cell, especially in the case of T cell education in thymus, remains unclear. We have developed three lines of HLA-DRA transgenic mice by introducing the genomic DRA genes with different 5 '-flanking sequences into $\mathrm{C} 57 \mathrm{BL} / 6$ mice. Immunohistochemical and flow cytometric analyses revealed that $\mathrm{DR} \alpha E \beta^{\mathrm{b}}$ molecules were expressed on all of immunocompetent cells in line 24 , and were expressed on TEC and a limited proportion of thymic B, splenic DC and splenic $\mathrm{B}(\mathrm{SB})$ in line 60. On the other hand, the expression of the molecules in the line 30 was confined to TEC. Moreover, taking advantage of the monoclonal antibody, Y-Ae, which recognizes DR $\alpha 56-72 / \mathrm{I}-\mathrm{A}^{\mathrm{b}}$ complex, we found that DR $\alpha 56$ $72 / \mathrm{I}-\mathrm{A}^{\mathrm{b}}$ was expressed on medullary TEC and SB in line 24 , but only on medullary TEC in line 30 . These transgenic mice will facilitate the in vivo investigation of the role of TEC in the process of positive and negative selection of the T cell repertoire . 
FUNCTIONAL EXPRESSION OF DR $\alpha$ A $\beta 9$ MOLECULES IN H-29 HOMOZYGOUS MICE. K.YAMANE, K.YAMAMOTO, Y.FUKUI, Y.ESAKI, A.KIMURA and T.SASAZUKI,(Dept.Genet.,Med.Inst. Bioreg.,Kyusyu Univ.,Fukuoka,Japan)

MHC class II morecules are heterodimeric glycoprotein and play a crucial role in the immunological processes. Recently, trans-locus heterodimer $\mathrm{E} \alpha \mathrm{Abq}$ were reported to be expressed and to eliminate $\mathrm{Mls}-\mathrm{1}^{\mathrm{a}}$ reactive $\mathrm{T}$ cell repertoire. To investigate whether the $\mathrm{DR} \alpha$, human homologue $\mathrm{E} \alpha$, could be expressed in association with $A \beta \mathrm{A}, \mathrm{C} 57 \mathrm{BL} / 6$ mice expressing HLA-DRA gene were backcrossed with DBA/1 mice which lack the expression of both E $\alpha$ and $E \beta$ genes. Spleen cells from DRA+,H-2q/q mice were stained with HLA-DR-specific monoclonal antibody (L243) and immunoprecipitation using L243 and MKD6 (anti I-A $\beta^{q}$ ) indicated that the DR $\alpha$ chain was associated with $A \beta q$ chain. The expression of DR $\alpha A \beta q$ molecules as well as E $\alpha A \beta q$ resulted in the elimination of Mls- $1^{\mathrm{a}}$ reactive $\mathrm{T}$ cell repertoire, suggesting that Mls-1a antigen could bind to $D R \alpha A \beta q$. The amino acid residues which are conserved between $D R \alpha$ and $E \alpha$, but are different from those of $A \alpha q$ are located in the inside of the antigen binding groove. Therefore, it is conceivable that the amino acid residues critical for binding of exogenous super antigen(SEB) and endogenous super antigen(Mls- $1^{\mathrm{a}}$ ) are different. The elimination of Mls-1a reactive T cell reppertoire in DRA(+)q/q mice did not affect the development of CIA, suggesting these $T$ cell repertoires are not involved in the development of CIA, at least, in $\mathrm{DBA} / 1$ mice.

\section{B 48}

PREVENTION OF INSULITIS IN NOD MICE BY MHC CLASS I Ld MOLECULES. Jun-ichi MIYAZAKI (Dept. of Dis.-related Gene Reg. Res (Sandoz), Fac. of Med., Univ. of Tokyo, Tokyo), Yoichi MATSUDA (Div. of Genet., Natl. Inst. of Rad. Sci., Chiba), Toru MIYAZAKI, Tetsushi TOYONAGA and Ken-ichi YAMAMURA (Inst. of Mol. Embryol. \& Genet., Kumamoto Univ. Med. Sch., Kumamoto)

NOD mice spontaneously develop an autoimmune disease similar to insulin-dependent diabetes mellitus (IDDM) in humans. NOD mice express $\mathrm{MHC}$ class $1 \mathrm{Kd}$ and $\mathrm{D}^{\mathrm{b}}$ antigens. To examine the possible involvement of MHC class I molecules in the development of insulitis, we attempted to express a different type of class I molecule in NOD mice by crossing C57BL/6 mice transgenic for the class I Ld gene to NOD mice. The backcross progeny expressed the $L d$ antigen on the peripheral blood lymphocytes (PBL) at high levels. The cell surface expression of endogenous class I and class II antigens on the PBL was not affected. Analysis of these mice revealed that the expression of class I Ld antigen significantly reduced the incidence of insulitis at 20 weeks of age. In situ hybridization showed that the $L^{d}$ transgene was located on chromosome 6 with which no genetic linkage to IDDM was demonstrated. These results suggest that the NOD type class I molecules are involved in the development of insulitis in NOD mice. 
B 49

GENETIC ANALYSIS OF TRANSIENT HYPERGLYCEMIA IN NOD MICE TRANSGENIC FOR INSULIN-SV40 T ANTIGEN GENE.

Fumi TASHIRO Jun-ichi MIYAZAKI (Dept. Disease-related Gene. Reg. Res. (Sandoz), Fac. of Med., Univ. of Tokyo, Tokyo) and Ken-ichi YAMAMURA (Inst. of Mol. Embryol. \& Genet., Kumamoto Univ., Kumamoto)

We previously made transgenic mice (B6-IT3) by introducing insulin promoter-SV40 $\mathrm{T}$ antigen gene into $\mathrm{C} 57 \mathrm{BL} / 6$ mouse eggs. These mice repeatedly developed $\beta$ cell tumors at the age of $\sim 12$ weeks. When one line of these mice was crossed and further backcrossed to NOD mice several times, the progeny (NOD-IT3) exhibited hyperglycemia (blood sugar $>500$ $\mathrm{mg} / \mathrm{dl}$ ) at 4 6 weeks of age, but gradually became hypoglycemic due to the development of $\beta$ cell tumors. We examined the serum level of immunoreactive insulin (IRI) of hyperglycemic mice and found that $I R I$ was low in spite of high blood glucose. Therefore, the transient hyperglycemia was probably caused by $\beta$ cell dysfunction. Genetic analysis was performed by crossing NOD-IT3 mice with other inbred strains of mice. The result suggested that this hyperglycemia is controled by a single recessive gene which is unlinked to $\mathrm{H}$ 2. Linkage analysis of the putative gene with the diabetes susceptibility genes (Idd-3, $/ d d-4$ and $/ d d-5)$ is in progress.

\section{B 50}

SEQUENCE OF AN UNKNOWN HUMAN GENE WITH REFERENCE TO RETINOBLASTOMA GENE. Kazuhiko WAKABAYASHI (Dept. Biochem., Yamanashi Medical College, Yamanashi)

A cDNA library from human fetal retina was screened with a probe, 1267 nt long genomic DNA fragment obtained from a Japanese CDNA cosmid library. The probe has exons 25 and 26 of human retinoblastoma (RB) gene as well as surrounding intron sequences. Positive plaques were rescreened under reduced stringency. After rescue of phagemid with $f 1$ helper phage, pBluescript was isolated. Inserts were analyzed and selected for DNA other than RB gene. One of these inserts, DNA 47, which was $2.9 \mathrm{~kb}$ long, was analyzed with an automated sequencer. An ORF of 1725 nt was recognized. FASTA progam was used to search GenBank Database. A sequence of $1541 \mathrm{nt}$ at $5^{\prime}$ end had only weak homology to few primate entries. A sequence at $3^{1}$ end showed, however, significant fit to transposon-like human element $(81.7 \%$ ID in 175 nt overlap) and also to several human ESTs. 
Regulaion of expression of the retinoblastoma (RB) gene. Tomoko HASHIMOTO1), Hideki SHINDO2), Yasuhiro SOTOZONO1.3), Atusko OGAWA11. Ei-ichi TANI2), Rei TAKAHASH (4) and Jun-ichi FURUYAMA1) 1)Dept. Genet., 2) Dept. Neurosurg., Hyogo Coll. Med., Nishinomiya, 3) Dept. Pediatr., Kyoto Pref. Univ. Med., Kyoto, 4) Dept. Pathol., Faculty of Med., Kyoto Univ., Kyoto

As the RB gene product has been known to be one of the key factors which suppress cell growth at G1 stage, we examined the expression level of the RB gene in an early G1 stage using human fibroblasts. Cells were arrested by serum deprivation and released by adding FCS. The RB gene was expressed transiently after 30 minutes of stimulation. This expression pattern is quite similar to that of the c-fos gene. In order to know the role of the RB gene in vivo, we transfected the RB gene into a RB-negative cell line, HTB9, and established RB-positive cell line, $\mathrm{HCl}-2$. At confluency, the c-fos gene was highly expressed in $\mathrm{HCl}-2$ cells but not in HTB9 cells. In contrast, the c-myc gene was highly expressed in HTB9 cells but not in $\mathrm{HCl}-2$ cells. These results suggest that corelation exists between c-fos expression and RB expression, and that inverse relationship exists between c-myc expression and RB expression.

\section{B 52}

CHROMOSOME ANALYSES IN CULTURED COLON CARCINOMA CELLS FROM PATIENTS WITH HEREDITARY NONPOLYPOSIS COLORECTAL CANCER SYNDROME. Tatsuro IKEUCHI ${ }^{1}$, Mitsuaki A. YOSHIDA $^{1}$, Takeo IWAMA ${ }^{2}$, Michiko MIYAKI ${ }^{3}$, and Akira TONOMURA ${ }^{1}{ }^{1}$ Dept. Cytogenet., Med. Res. Inst. ${ }^{2}$ Ctr. Polypos is Intest. Dis., Tokyo Med. Dent. Univ., Tokyo, ${ }^{3}$ Dept. Cancer Biochem., Tokyo Metrop. Inst. Med. Sci., Tokyo)

In hereditary nonpolypos is colorectal cancer (HNPCC, or Lynch syndrome), chromosomal locus of the gene has not been known. We report here the results of chromosome analyses in cultured colon cancer cells from 2 HNPCC patients. [Case 1] A male, aged 63 yrs. Short-term cultures were made from the cancer metastasized from colon to liver. A modal chromosome number was 60 , and there were various types of chromosome anormalities, including -8 (found in $92 \%$ of cells analyzed), $-Y(88 \%),-22(88 \%),-21(79 \%),-18(75 \%), \operatorname{der}(19) t(1 q ; 19 q)$ $(67 \%), \mathrm{i}(18 \mathrm{q})(50 \%)$, and other unidentified marker chromosomes. [Case 2] A male, aged 47 yrs. A long-term cultured cell line ("NoTa") has been successfully established from a colon cancer, and maintained for more than 2 yrs with a stable growth rate. The cells were of typically epithel ial type and conf irmed to be tumorigenic in nude mice. During the course of prolonged culture, most cells showed a normal male karyotype with no clonal chromosome abnormalities. Polymorphic DNA marker analyses revealed no allelic loss of chromosomes $1,5,17,18$ and 22. Further studies on both chromosomal and molecular levels are needed in NoTa cells and in other tumor samples, in order to identify any specifically abnormal chromosome, on which the gene of HNPCC might be located. 


\section{B 53}

CHROMOSOME ANALYSES OF ADENOMATOUS POLYPS FROM THE PATIENTS WITH FAMILIAL ADENOMATOUS POLYPOSIS. Mitsuaki A. YOSHIDA ${ }^{1}$, Tatsuro IKEUCHI ${ }^{1}$, Isao OKAYASU $^{2}$, Takeo IWAMA ${ }^{3}$ and Akira TONOMURA ${ }^{1}$ ('Dept. Cytogenet., Med. Res. Inst., ${ }^{2}$ Dept. Pathol., Hosp., " ${ }^{3}$ Centr. Anal. Polypos is \& Intest., Tokyo Med. \& Dent. Univ., Tokyo)

Karyotype analyses were successfully performed on colorectal polyps developed in patients with familial adenomatous polyposis (FAP). Mitotic cells available for analys is were obtained from short-term cultures of 49 individual polyps and of 13 specimens of mixed polyps from 22 patients. No chromosome abnormalities were observed in 2 cultured specimens, and the remaining 60 cultures showed clonal and/or nonclonal chromosome changes in both structure and number. Among these, most frequent abnormality was trisomy $\# 7$, which was identified in 18 cultures. Gain of \#13 was also found in 10 cultures, and loss of \#10 in 7 cultures. Structural changes involving $\# 1 p$, $\# 5 q$ and $\# 10 q$ were also frequently found. There was no apparent relationship between gains of chromosomes 7 and 13 and size of the polyps. Of special interest was the findings that deletions of $\# 1 p$, \#5q and $\# 10 q$ were detected in even small-sized polyps with mild or moderate dysplasia. Most of the above chromosome abnormalities were identified in polyps with histopathologically moderate pattern Further study is needed in order to elucidate the significant roles of the specific chromosome changes in the pathogenesis of colorectal adenomatous polyps.

\section{B 54}

A SUMMARY OF 104 GERM-LINE MUTATIONS IN FAMILIAL ADENOMATOUS POLYPOSIS PATIENTS. Hiroki NAGASE ${ }^{1,2}$, Yasuo MIYOSHI ${ }^{1}$, Akira HORII ${ }^{2}$, Takahisa AOKI $^{1}{ }^{2}$, Shigetoshi ICHI I ${ }^{1}$, Shuichi NAKATSURU ${ }^{2}$, Michio OGAWA $^{2}$ and Yusuke NAKAMURA ${ }^{1}$ ('Dept. Biochem. Cancer Inst., Tokyo, ${ }^{2}$ 2nd Dept. of Surg. Kumamaoto Univ., Kumamoto)

We report here the result of a screening for germ-line mutations in the adenomatous polyposis coli (APC) gene. Examination of the entire coding region of the APC gene, based on a ribonuclease protection assay coupled with the polymerase chain reaction (PCR), disclosed mutations that were considered to cause significant defects in the APC product in 104 of 165 unrelated familial adenomatous polyposis (FAP) patients. Our findings revealed the following features of the germ-line mutations of APC: (i) the great majority of the mutations found were resulted in truncation of the APC product; (ii) almost all of the mutations were located within the first half of the coding region; (iii) no correlation was observed between the locations of germ-line mutations and extra-colonic manifestations in FAP patients. our results provide information helpful to an understanding of the APC gene, and will also contribute to presymptomatic diagnosis of members in FAP families. 


\section{B 55}

INACTIVATION OF BOTH ALLELES OF THE APC GENE IS ESSENTIAL FOR THE INITIATION OF COLORECTAL TUMORS. Shigetoshi ICHII $^{1,2,3}$, Akira HORII ${ }^{1}$, Yasuo MIYOSHI ${ }^{1}$, Shuichi NAKATSURU ${ }^{1}$, Satoshi TAKEDA ${ }^{1}$, Hiroki NAGASE $^{1}$, Takahisa AOKI ${ }^{1}$ Junich $i$ FURUYAMA $^{2}$, Joji UTSUNOMIYA ${ }^{3}$, and Yusuke NAKAMURA ${ }^{1}$ ('Dept. $^{1}$. Biochem. Cancer Inst., Tokyo, ${ }^{2}$ Dept. Genet. and ${ }^{3} 2$ nd. Dept. Surg. Hyogo Med. Col.)

Whether the dosage effect of germ-line mutation of the APC gene is sufficient, or an additional somatic mutation of the remaining normal allele is required as well to cause colorectal tumors, we examined germ-line and/or somatic mutations of the APC gene in tumors developed in familial adenomatous polyposis (FAP) and non-FAP patients. Genetic alterations in both alleles of the APC gene were detected in 14 of 31 adenomas $(45.2 \%$ ) and 16 of 47 carcinomas (34.0\%). We further investigated alterations of the APC gene in earlystage adenomas obtained from one FAP patient and detected two-hit mutations in 10 of 15 tumors $(66.7 \%)$. These results clearly indicated that the inactivation of both alleles of the APC gene is essential for the development of an earlystage adenoma, in agreement with the two-hit theory underlying the concept of tumor suppressor genes.

\section{B 56}

SOMATIC MUTATION OF THE APC GENE IN HUMAN GASTRIC CANCER. Akira HORII ${ }^{1}$, Shuichi NAKATSURU ${ }^{1}$, Akio YANAGISAWA ${ }^{2}$, Yo KATO ${ }^{2}$, Yusuke NAKAMURA ${ }^{\perp}$ (Depts. ${ }^{1}$ Biochem. and ${ }^{2}$ Pathol., Cancer Inst. , Tokyo)

We searched for somatic mutations of the adenomatous polyposis coli (APC) gene in DNA samples isolated from 57 sporadic gastric cancers, by means of a ribonuclease (RNase) protection analysis coupled with DNA amplification by the polymerase chain reaction (PCR). Examining $30 \%$ of the APC coding region, including a region where somatic mutations in colorectal tumors are known to be clustered, we detected somatic mutations in 12 tumors; seven in 17 very well differentiated adenocarcinomas, two in 19 well or moderately differentiated adenocarcinomas, and three in ten signet-ring cell carcinomas. So far, no somatic mutations have been identified in 11 poorly differentiated adenocarcinomas. Eight of the 17 somatic mutations found in 12 tumors caused truncation of the gene product due to a nonsense mutation and a 1-, 2- or 5-bp deletion; nine others were point mutations that altered amino acids. our results suggest that inactivation of APC plays a role in development of some gastric cancers, particularly very well differentiated adenocarcinomas and signet-ring cell carcinomas. 
C 1

THE DENTATORUBROPALIIDOLUYSIAN ATROPHY(DRPLA): LINKAGE ANALYSIS WITH DNA MARKERS.Ikuko KONDO(Dept.of Hygiene, Ehime Univ. ,Ehime), Masao YAMADA(Div. of Con. Anomaly. , Nat. Child. Hospital, Tokyo), Hitoshi OHTA(Dept.of Psychiatry, Kohchi Medical School, Kohchi), Mitsuyasu YAZAKI(Dept.of Psychiatry, Yamagata Univ.), and Ichiro KANAZAWA(Dept.of Neurol. Univ. of Tokyo, Tokyo)

The dentatorubropallidoluysian atrophy (DRPLA) is an autosomal dominant neurogenerative disease. The cause of the disease is unknown and the locus for the DRPLA has not been assigned. We have studied for linkage between the locus for DRPLA and polymorphic loci on several different chromosomes in six families. There were negative scores at recombination fraction of 0.01 or 0.05 between the locus for DRPLA and many DNA markers. However, the maximum lod score was 0.9 at recombination fraction $\theta=0.0$ between the locus for the DRPLA and INSR, aJthough the score was not significant for assignment of the gene.

\section{2}

Linkage analysis of a new syndrome of autosomal recessive spinocerebellar degeneration associated with hypoalbuminemia. Hajime TANAKA, Ryoko KOIKE, Shoji TSUJI (Dept. Neurol. ,Brain Res. Inst. ,Niigata Univ. ,Niigata), Tatsuhiko YUASA, Tadashi MIYATAKE (Dept. Neuro1., Tokyo Med. Dent. Univ., Tokyo), Kazutoshi UEKAWA (Tamakina-So, Kumamo to), Nobuhiko FUKUHARA (Dept. Neurol., Nat1. Sanatorium Saigata Hosp., Niigata), Yoshinori TANNO (Dept. Neurol., Nat1. Sanatorium Nishi-Ojiya Hosp., Niigata), Nobuhiko TAKASAWA (Kanagawa Rehabilitation Center, Kanagawa), Tadashi HIROI (Hosoki Hosp., (Training School and Hosp. Nagaoka Ryoikuen, Niigata), Kiyoshi IWABUCHI (Dept. Neuropathol, , Psychiatric Res. Inst. Tokyo, Tokyo), Shuji HANIHARA (Kanagawa Rehabilitation Center, Kanagawa), Tadashi HIROI (Hosoki Hosp., Kochi), Hisao IKEDA (Dept. Psychi., Kochi Med. School, Kochi), Kenshi HAYASHI (Oncogene Div., Nat1. Cancer Res. Inst., Tokyo)

We have identified a new syndrome of autosomal recessive spinocerebellar degeneration associated with hypoalbuminemia (SCD-HA). Utilizing 32 members of 7 families including 16 affected individuals, we have analyzed linkage between the locus for the SCD-HA and 5 microsatellite polymorphisms on the short arm of chromosome 9 (GS4/D9S15/GS2 (9q13-21.2), D9S56, and D9S58). Although 3 recombination events between the disease locus and GS4/D9S15/GS2 were observed, the maximum lod score of $4.108 \quad(\theta=0.10)$ is obtained. The result raises the possibility that the gene for the SCD-HA is located near the GS4/D9S15/GS2. As no recombination has been observed between FRDA and GS4/D9S16/GS2, the gene for the SCD-HA is likely to be caused by new gene adjacent to FRDA gene. 
C 3

LINKAGE ANALYSIS OF HEREDITARY SPINOCEREBELLAR ATAXIAS--PRECISE MAPPING OF SCA1 GENE. Akemi WAKISAKA, Hidenao SASAKI, Kunio TASHIRO (Dept. Pathol. and Neurol., Hokkaido Univ., Sch. Med., Sapporo) and Michihiro YOSHIDA (Chromosome Res. , Fac. Sci., Hokkaido Univ., Sapporo)

Hereditary olivo-ponto-cerebellar atrophy (OPCA) is revealed to be genetically heterogenous neuro-degenerative disorders in Japanese. It means that one form is linked with D6S89 and called as SCA1 while others are not. Out of Japnese 17 hereditary OPCA pedigrees 8 pedigrees were proved to be SCA1 based on the linkage with D6S89. Five 6p DNA polymorphic markers were investigated for precise mapping of SCA1 gene. Multipoint-linkage were computed by LINKAGE program. The results showed that most likely gene order of $6 \mathrm{p}$ markers is (cen)-HLA-D6S109-D6S89-D6S202-F13A1-(tel). The highest location scores of SCA1 were obtained around D6S202 between F13A1 and D6S89. The weak linkage disequilibrium was observed with D6\$202.

Linkage study was also performed for 17 pedigrees of Joseph disease with 12 newly developped micro satellite polymorphic markers. none of them including AMY2 which was supposed to be linked with MJD showed close linkage to MJD locus.

\section{4}

\section{PHYLOGENY AND GENETIC DIVERSITY OF HUMAN POPULATIONS BASED ON HLA POLYMORPHISM}

Tadashi IMANISHI, Keiichi OMOTO (Department of Anthropology, Faculty of Science, The University of Tokyo, Tokyo), and Takashi GOJOBORI (DNA Research Center, National Institute of Genetics, Mishima)

The frequencies of 19 HLA-A and 42 HLA-B alleles in 77 ethnic groups in the world were analyzed by using two statistical methods: the clustering analysis and the principal component analysis (PCA). We could show the evolutionary relationships of closely related ethnic groups by constructing an UPG dendrogram. The dendrogram contained six large clusters that corresponded to Africans, Caucasoids, north Asians, southeast Asians, Amerinds, and Oceanians. The Japanese population, which belonged to the north Asian cluster, was genetically closest to Koreans. By the PCA of 59 independent HLA alleles, we found that genetic diversity in Mongoloid populations was very high compared with those in other major groups. This suggests a high genetic differentiation among Mongoloid populations. We also found that southeast Asians and Oceanians are highly diverged to each other, though these groups are geographically very close. 
C 5

\begin{abstract}
DIFFERENT WAVES OF MIGRATION INTO THE NEW WORLD INFERRED FROM MITOCHONDRIAL DNA SEQUENCE POLYMORPHISMS. Satoshi HORAI, Rumi KONDO, Yuko N-HATTORI, Seiji HAYASHI (Dept. Human Genet., Nat. Inst. Genet., Mishima), Shunro SONODA (Dept. Virol., Kagoshima Univ., Kagoshima) and Kazuo TAJIMA (Div. Epidemiol., Aichi Cancer Center Research Inst., Nagoya)
\end{abstract}

Nucleotide sequence analysis of the major noncoding region of human mtDNA from various races was extended with 72 native Americans from 16 different local populations (nine populations from Chile, four from Colombia, one each from Brazil, Maya and Apache Indians). Based on a comparison of the 482 base pair sequences in the 72 native Americans, 43 different types of mtDNA sequences were observed. The nucleotide diversity within the native Americans was estimated to be $1.29 \%$, which is slightly less than the value of $1.44 \%$ from the total human population including Africans, Europeans and Asians. Phylogenetic analysis revealed that most native American lineages are classified into four major distinct clusters. A phylogenetic tree of 193 individuals in the total human population indicated that the four native American clusters are distinct and dispersed in the tree. These clusters almost exclusively consist of native Americans, with only a few Asians if any. We postulate that respective four ancestral populations gave rise to different waves of migration to the New World. Furthermore, sequence differences in all pairwise comparison of native Americans showed a bimodal distribution which is significantly different from Poisson. These results suggest that the ancestral native American population neither underwent severe bottleneck nor rapid expansion in population size during the migration of people into the Americas.

\title{
C 6
}

A Y-ASSOCIATED ALLELE POSSIBLY CHARACTERISTIC OF CERT AIN ETHNIC GROUPS IN ASIA. K. TANAKA T. IHDA, Y. NAKAHORI (Dept. Hum. Genet., Tokyo Univ., Tokyo), A. AKANE Y. YAMORI (Dept. Legal Med. and Dept. Path., Shimane Med. Univ.,Izumo,Japan), D. K. JIN (Dept. Im mun., Natl. Child. Ctr., Tokyo), Y. NAKAGOME (Dept. Hum. Genet., Tokyo Univ., Tokyo)

The probe $47 \mathrm{z}$ detects DNA polymorphisms on both the $\mathrm{X}$ and $\mathrm{Y}$ chromosomes. Blood samples were collected from Japanese, Korean, Chinese, Jewish, Caucasian and Negro populations and polymorphisms of both loci were examined. Both Y1 and Y2 alleles were detected in Japanese and Koreans. However, only the Y1 allele was detected in eacn of the other populations. Although both $\mathrm{X} 1$ and $\mathrm{X} 2$ alleles were detected in all examined populations, the frequency of the $\mathrm{X} 2$ allele was very low among Negroes. 
C 7

\author{
AS TO AN ETHNIC DIFFERENCE IN THE LINKAGE DISEQUILIBRIUM \\ CONCERNING AUTOSOMAL RECESSIVE GENETIC DISEASES. \\ Naovuki KAMATANI, Sanae OTSUKA, Masayuki HAKODA, Hisashi YAMANAKA, \\ Chihiro TERAI, Sadao KASHIWAZAKI \\ (Inst. of Rheumatol., Tokyo Women's Medical College)
}

We examined linkage disequilibrium between the mutation site of $A P R T^{*} J$ and polymorphic sites located within and near the gene. $A P R T^{*} J$ is the most common mutant allele of APRT deficiency among Japanese (gene frequency:approx. 0.42\%). Haplotypes were determined for $67 A P R T * J$ alleles and 194 normal alleles. Normal APRT alleles are highly polymorphic as to Sph and hTaq located $3.8 \mathrm{~kb}$ and $1.1 \mathrm{~kb}$ upstream of the $A P R T^{*} J$ mutation site. Between the $A P R T^{*} J$ site and the other two sites, marked linkage disequilibrium was found. These data indicate that all $A P R T^{*} J$ alleles were derived from a single mutation which occurred before a large number of generations. Similar data have been published as to mutant genes of cystic fibrosis, alpha-1-antitrypsin deficiency and medium-chain acyl-CoA dehydrogenase deficiency that are very common among the caucasoid population. Comparison of our data with others indicated that these caucasoid disease-related mutations are with much stronger linkage disequilibrium with near-by flanking sequences. Along with other genetic data, we consider this ethnic difference in the linkage disequilibrium a reflection of the difference in the population size between Mongoloid and Caucasoid after ethnic divergence. We consider the effective population size has been broadly Mongoloid > Caucasoid.

\title{
C 8
}

VERIFICATION OF A PROPOSED PHYLOGENY FOR THE PRINCIPAL ALLELES OF HUMAN PHOSPHOGLUCOMUTASE-1 (PGM1) BY DNA SEQUENCING

Norio TAKAHASHI, Yasukazu KIMURA, Junko KANEKO, Hideo OMINE, and Chiyoko SATOH

(Dept. of Genetics, Radiation Effects Research Foundation, Hiroshima)

The diversity of the $P G M 1$ gene can be easily detected by electrophoresis and is thus a particularly useful marker for human genetic research and forensic medicine. In all of the populations investigated by starch gel electrophoresis and isoelectric focusing, four different common alleles (PGM1*1+,1-,2+, 2-) encoding PGM1 were observed in polymorphic proportions. Carter et al. proposed phylogenic model concerning the formation of these four alleles, and we expanded this hypothesis to eight genes by adding four alleles observed in the Japanese population $\left(P G M I^{*} 3+, 3-, 7+, 7-\right)$. The phylogeny postulated that the eight alleles may be explained by three base substitutions and four recombination between the substitutions. In other words, crossover plays as significant a role as base substitution in the generation of allelic diversity of $P G M 1$. Whitehouse et al. reported the full mRNA sequence of human PGM1. Therefore, mRNA obtained from Japanese individuals, in which four kinds of genes $\left(P G M I^{*} 1+, 1-, 2+\right.$, 2-) are presumed to exist by electrophoresis, was amplified by the RT-PCR method and the sequence was determined. The 221st amino acid of type 1 (1+ and 1-) was Arg, while that of type $2(2+$ and 2-) was Cys. Also, the His residue of type "-" (1- and 2-) was substituted for a Tyr of type "+" $(1+$ and $2+)$ at the 420th position. These results suggest that the four phenotypes were formed not by three base substitutions occurring independently, but by two substitutions and one crossover. This strongly supports our proposed phylogeny. Furthermore, we are now analyzing human mRNA that shows four other kinds of phenotype. 


\section{9}

DISCOVERY OF A GENETIC POLYMORPHISM OF HUMAN PLASMA PROTEIN C INHIBITOR (PCI). Ko ichiro KISHI, Toshihiro YASUDA, Daita NADANO, Haruo TAKESHITA, and Reiko IIDA (Dept. Legal Medicine, Fukui Medical School, Fukui)

The objectives of this study were to determine the genetic basis of the electrophoretic differences of human plasma protein $\mathrm{C}$ inhibitors (PCI) from 977 individuals. Three discrete antibodies were produced against the PCI purified from human plasma and peptides that corresponded to the $\mathrm{N}$-terminal 15 amino acid residues and the C-terminal 15 residues of human PCI [Biochem. Int., 25:553-560, 1991]. The combined techniques of polyacrylamide gel isoelectric focusing and immonoblotting with these three different antibodies resolved the plasma PCI into several isoprotein bands, with a pH range of 6-7. These PCI isoproteins, however, were not stained by antihuman kallikrein, anti-human protein $\mathrm{C}$ or anti-human urokinase antibodies. Therefore, each of the PCI bands, which were detected by inmunoblotting with the anti-bodies, were derived from free PCI, and not an inactive PCI species. Two common phenotypes, designated PCI 1 and 1-2, were recognized, and family studies showed that they represented homozygosity or heterozygosity for two autosomal codominant alleles, $\mathrm{PCI}^{*} 1$ and $\mathrm{PCI}{ }^{*} 2$. A population study of plasma samples collected from 977 Japanese individuals indicated that the frequencies of the $\mathrm{PCI}^{*} 1$ and $\mathrm{PCI}^{*} 2$ alleles were 0.988 and 0.012 , respectively [Hum. Genet., $\overline{89: 265}-269,1992$ ].

\section{10}

GENETIC POLYMORPHISM OF HUMAN DEOXYRIBONUCLEASE II (DNaSe II). Toshihiro YASUDA, Daita NADANO and Koichiro KISHI (Dept. Legal Med., Fukui Medical Scool, Fukui)

The objectives of this study were to elucidate the genetic basis of human deoxyribonuclease II (DNase II). We have devised a specific and highly sensitive assay method for the urinary and leukocytic enzymes [Yasuda et al., Biochim. Biophys. Acta, (1992) 1119, 185-193]. The distribution of the activities of DNase II in urine and leukocytes displayed clear-cut bimodality and the Japanese study population could be classified into two distinct types, namely low-activity (DNASE2 L) and high-activity (DNASE2 H), which indicates the existence of a genetic polymorphism in the activity levels of urinary and leukocytic DNase IIs. Close correlations between the leukocytic and urinary enzyme activity levels from the same individuals were observed and the types in the leukocyte samples agreed with the types found in the corresponding urine samples. In a population study of 528 unrelated Japanese individuals, the gene frequencies of the low activity (DNASE2 ${ }^{*} \mathrm{~L}$ ) and the high activity (DNASE2*H) alleles were calculated to be 0.632 and 0.368 , respectively. The family study results were compatible with the model that the low activity type is due to an autosomal recessive allele. Ref) Yasuda et al., Ann. Hum. Genet., (1992) 56, 1-10. 
C 11

\section{ISOLATION OF cDNA ENCODING Rh POLYPEPTIDE FROM A FAMILY WITH Rh D-POSITIVE AND Rh D-NEGATIVE PHENOTYPES. Euminori_UMENISHI, Eiji KAIII, Takashi OYAMADA and Shigenori IKEMOTO (Dept. Legal Med. \& Hum. Genet., Jichi Medical School, Tochigi)}

We previously reported two cDNA clones encoding Rh polypeptides and both showed an open reading frame composed of 1251 nucleotides. To investigate the genetic basis of $\mathrm{Rh}$ polypeptide gene, we attempted the isolation of the cDNA clones for Rh polypeptides from a family with $\mathrm{Rh}$ D-positive and D-negative phenotypes in the RT-PCR method from each reticulocyte RNAs, followed by subcloning with the $\mathrm{pCR}^{\mathrm{TM}} 1000$ vectors. The subcloned cDNAs were all found the plural clones associated with Rh polypeptides besides the above two clones. This result suggests that the variants of $R h$ polypeptides are encoded by the plural cDNAs and the appearance of these clones makes $\mathrm{Rh}$ inheritance more complex.

\section{12}

ISOLATION OF CDNA CLONES ENCODING Rh POLYPEPTIDES FROM AN $\mathrm{RH}_{\text {null }}$ INDIVIDUAL. Eiji KAIII, Euminori UMENISHI, Junji TSUMOTO and Shigenori IKEMOTO (Dept. Legal Med. \& Hum. Genet., Jichi Medical School, Tochigi)

The phenotype of $\mathrm{Rh}_{\text {null }}$ in the $\mathrm{Rh}$ blood group system completely fails to react with all $\mathrm{Rh}$ antibodies. Recently, two cDNA clones encoding Rh polypeptides have been reported. Both cDNA clones have shown an open reading frame composed of 1251 nucleotides. We tried to clarify whether these cDNA clones are detected in an $\mathrm{Rh}_{\text {nul }}$ individual or not. To approach this problem, the detection of $\mathrm{Rh}$ polypeptide mRNAs in total RNAs from the reticulocytes was accomplished in the reverse-transcriptase polymerase chain reaction (RT-PCR) method followed by subcloning with the plasmid PCR 1000 vector. The nucleotide sequences of the subcloned cDNAs showed the presence of the two Rh polypeptide cDNA clones. This result suggested that some post-translational alteration of the Rh proteins or another protein may be needed to stabilize the $\mathrm{Rh}$ proteins in the red blood cell membrane. 
C 13

GENETIC POLYMORPHISM OF $\alpha$-L-FUCOSIDASE 2 IN JAPANESE POPULATION BY ISOELECTRIC FOCUSING AND INVESTIGATION OF CLINICAL SIGNIFICANCE IN OVARIAN CANCER PATIENTS. Yuji YOKOYAMA, Kouji NARAHARA, Kazushiro TSUJI, Shinsuke NINOMIYA and Yoshiki SEINO(Dept.Pediatr., okayama University Medical School, okayama)

The activity and genetic polymorphism by electric focusing of plasma $\alpha-L-F u c o s i d a s e ~ 2(F U C A 2)$ was assayed in 110 Japanese males and 225 Japanese females. Three different isoelectric focusing patterns were observed. Two of them were considered as homozygote (1-1.2-2). Heterozygote (1-2) had main bands specific to the 2 other types in addition to the common band. The frequencies and activities were $48.3 \%, 8.82 \pm 2.59 \mathrm{IU} / \mathrm{L}$ for type $1-1,40.6 \%$, $8.51 \pm 3.24 \mathrm{IU} / \mathrm{L}$ for type $1-2,10.1 \%, 5.91 \pm 1.43 \mathrm{IU} / \mathrm{I}$ for type $2-2$. The activity of type 2-2 was significantly low compared with 1-1 and 1-2. Type 2-2 can be considered as a low activity variant. The gene frequency of 1 and 2 was 0.693 and 0.307 respectively. FUCA2 is a highly useful genetic marker. The previously reported FUCA2 activities in epithelial ovarian cancer patients suggested that females with low activity of FUCA2 had a high risk for development of ovarian cancer. The investigation of the activities and genetic polymorphism in 17 ovarian cancer patients showed no stastical significance versus control values.

\section{14}

PEPSINOGEN C GENE POLYMORPHISM ASSOCIATED WITH GASTRIC ULCER. Takeshi AZUMA, Junichi KONISHI, Yoshie TANAKA Masamichi HIRAI, Yoshihiro KOHLI, and Norio FUJIKI (Second Dept. of Internal Medicine, Fukui Medical School, Fukui, Japan)

It has been accepted that genetic factors play an etiological role in peptic ulcer disease. A major difficulty in genetic studies of peptic ulcer has been the lack of subclinical markers of the disease. Analyzing restriction fragment length polymorphisms (RFLPs) may identify alleles at a particular genetic locus that are associated with clinical phenotype. The aim of the present study was to analyze RFLPs for pepsinogen genes as candidate genes for peptic ulcer disease. Genomic DNA was obtained from 60 healthy unrelated individuals, 30 gastric ulcer patients, and 30 duodenal ulcer patients. The DNA was digested with EcoRI and subjected to Southern analysis using labeled pepsinogen $\mathrm{A}$ (PGA) and pepsinogen $\mathrm{C}$ (PGC) $\mathrm{CDNA}$ probes. RFLPs of PGA were not detected in Japanese. A two allele $100 \mathrm{bp}$ insertion/deletion polymorphism for PGC was observed in the present study. The allele frequencies of the large and the small fragment were 0.81 and 0.19 in controls, 0.64 and 0.36 in patients with gastric ulcer, and 0.75 and 0.25 in patients with duodenal ulcer. The frequency of the small fragment was significantly higher in patients with gastric ulcer than in controls. These results suggest that there is an association between genetic polymorphisms at PGC locus and gastric ulcer disease, and that PGC RFLP appears to be a good subclinical marker of the genetic predisposition to gastric ulcer. 


\section{15}

HETEROGENEITY OF SILENT TYPE SERUM CHOLINESTERASE VARIANTS FOUND IN CHUGOKU AND IN SHIKOKU DISTRICT. Kazuo HIDAKA, Iwao IUCHI, Toshiko YAMASAKI, Ryuichi KAM0I ${ }^{*}$ (Dept. Biochem. \& Int. Med*., Kawasaki Med. Sch., Kurashiki), Kohsaku GOTOH(Sakaki bara Hosp., Okayama) and Minoru KUWASHIMA (Kagawa Prof. Cent. Hosp. Takamatsu)

There are three phenotypes of serum cholinesterase (SChE) variants, namely dibucaine-resistant, fluoride-resistant and silent. High frequency (more than 30 families) of the silent ChE variant were reported in past in the Japanese probably because it is measured as one of the routine clinical laboratory test all over Japan. Recently, we clarified aberrant DNA sequence of nine homozygote and four heterozygote silent genes from six unrelated families in Chugoku and Shikoku area. The 1st family demonstrated a $G \rightarrow C$ transversion at codon 365 , which was followed to see in two individuals of the same family. This mutation was resulted to create a new Taq 1 restriction site. Then the four individuals of next following 2 nd, $3 \mathrm{rd}$ and 4 th familiès were confirmed the same mutation without trouble by RFLP method with Taq 1 . The second mutation in 5th family revealed that two members were in a compound heterozygous condition, i.e. 1)a frameshift mutation produced by an extra $A$ insertion at codon 315 and 2) the same point mutation at codoc 365 as seen the first instance. The 6 th family was a $A \rightarrow$ Gtransition at codon 128 , detecting 4 carriers of the same base replacement.

\section{16}

\section{AMINO ACID SUBSTITUTION PREDICTED FROM GENOMIC DNA ANALYSIS IN BUTYRYLCHOLINESTERASE DEFICIENCY Masako ABE, Kenii SHIBUTA, Tomokazu SUZUKI (Dept. Clin. Genet., Med. Inst. Bioregulation, Kyushu Univ., Beppu), Shiro NOGUCHI (Noguchi Thyroid Clinic \& Hosp. Found., Beppu)}

To study molecular basis of butyrylcholinesterase (BChE) deficiency, nucleotide sequence of $\mathrm{BChE}$ gene and quantity of immunoreactive $\mathrm{BChE}$ protein from two kindreds were analyzed. In one kindred whose proband had trace BChE activity, we found two variant alleles. Direct sequencing of PCR products of BChE gene revealed G365R \& A539Y exonic point mutations in the proband who was homozygote of this mutant allele and who had few amount of BChE protein by Western blot analysis. Her three children who showed $1 / 5$ of normal activity were compound heterozygotes of G365R \& A539Y and L330l, and had the amount of protein corresponding to the reduced activity. G365R \& A539Y allele was also found in a proband of the second kindred who had trace BChE activity. From the secondary structure of these mutant proteins predicted by Chou and Fasman technique, G365R is supposed to lose one turn structure of BChE protein. This turn structure seems important because it also exists in human acetylcholinesterase protein. L330I imposes another beta sheet on BChE protein, and this amino acid residue is well conserved among cholinesterases in various species. Compared to these mutations, A539Y which is called $\mathrm{K}$ polymorphism might not change protein structure. It seems that the changes of structure brought by two variant alleles cause reduced amount and activity of BChE. 


\title{
C 17
}

MEASURED GENOTYPE APPROACH FOR IDENTIFYING MARKER POLYMORPHISMS TO NONMENDELIAN POLYGENIC HUMAN DISEASES. Norikazu YASUDA (Div. Genet., Nat1. Inst. Radiol. Sci., Chiba) and Hideo HAMAGUCHI (Dept. Med. Genet., Inst. Basic Sci., Univ. Tsukuba, Tsukuba)

Risk factors of coronary heart diseases (CHD) are the consequence of interactions between many genetic and environmental agents. Quantitative measures of plasma apolipoprotein $\mathrm{E}$ (Apo-E) are no doubt an example of risk factors among other things that link genetic and environmental factors to the CHD endpoint. Advents of molecular biology provide measures of the gene locus that codes for Apo-E. By measuring polymorphic protein variability, it is possible to assign polygenic effects to specific alleles or haplotypes. This measured genotype approach may be used to study polygenic components (number of loci involved, the frequencies and effects of alleles, and type of loci, structral and regulatory) of quantitative variation in apolipoproteins. A total of 303 healthy unrelated Japanese males is subjected to examine for an illustrative purpose of the analysis. It is found that the heritability in narrow sense of Apo-E polymorphism is circa 4 percent. A rather high contribution of dominance variance to Apo-E polymorphism might reflect complex interaction of Apo-E alleles to the level of total serum cholesterol.

\section{18}

\author{
A STUDY ON ALIELLIC ASSOCIATION OF SCHIZOPHRENIA WITH DINUCLEOTIDE \\ REPEAT POLYMORPHISMS AT DOPAMINE D2 RECEPTOR GENE AND D11S35 \\ LOCUS. Mineko HATTORI, Shinichiro NANKO, Tsukasa SASAKI, Hajime KAZAMATSURI \\ (Dept. of Psychiat. Teikyo Univ. School of Med. Tokyo), Shoji KUWATA, Takeo JUJI \\ (Dept. of Transfusion Med. and Immunohematol. Faculty of Med. Univ. of Tokyo, Tokyo) and \\ Katsushi TOKUNAGA (Dept. of Research, Jpn Red Cross Central Blood Center, Tokyo)
}

Results of family, twin and adoption studies have shown that genetic factors were of major etiological importance in schizophrenia. DRD2 gene has been implicated as a candidate gene for several mental disorders including schizophrenia. We have studied an association of schizophrenia with alleles of DRD2 and D11S35 which is located close to DRD2, using highly polymorphic microsatellite called CA/GT repeat, as markers. 70 patients samples were recruited at random from DSM-III-R schizophrenics of the outpatient clinic at Teikyo University Hospital (aged 19-64). 92 individuals were served as controls (aged 20-44). Genomic DNA was extracted from whole blood sample. We performed PCR to amplify the microsatellite at each locus, using specific primers. PCR products were detected by silver staining following electrophoresis. A microsatellite polymorphism with 6 common alleles was found for DRD2. 5 common alleles were detected for D11S35. Comparing the allele frequencies between two tested groups, we found no significant association at either locus. Althogh our xults do not support the D2 dopamine receptor hypothesis, several evidence has been reported, which suggests relationship between pathogenicity of schizophrenia and DRD2. More polymorphic markers should be examined before final conclusion. 
C 19

IDENTIFICATION OF GENOTYPES OF ADH2 AND ALDH2 AND THEIR RELEVANCE TO ALCOHOL SENSITIVITY AND ALCOHOL-DRINKING BEHAVIOR. Tatsuya TAKESHITA, Kanehisa MORIMOTO (Dept. Hyg. Prev. Med., Osaka Univ. Med. Sch., Osaka), Tomoko HASHIMOTO and Jun-ichi FURUYAMA (Dept. Genet., Hyogo Col. Med., Hyogo)

Polymorphism of class I alcohol dehydrogenase (ADH2) and low $\mathrm{Km}$ aldehyde dehydrogenase (ALDH2) have been considered to greatly affect alcohol sensitivity and drinking behavior. In the present study, both ADH2 and ALDH2 genotypes were determined in Japanese male workers by using PCR method. For ADH2, PCR product was cut by restriction enzyme Mae III. For ALDH2, PCR product was transfered to nylon-membrane by Southern-blotting and hybridized with allele-specific oligonucleotides. The observed distribution of ALDH2 genotypes was consistent with previous reports in the field of forensic medicine. Frequency of symptoms associated with alcohol sensitivity, such as flushing, headache, or palpitation, was distinctly different among the three ALDH2 genotypes. Drinking frequency was also significantly correlated with the ALDH2 genotype. By contrast, a contribution of $\mathrm{ADH} 2$ genotype appeared to be small.

\section{20}

The frequency of various class of meiotic disjunction in male and female heterozygotes for a balanced reciprocal translocations. T. Narukawa, M. Tanemura, T. Sumi, T. Iida, S. Okada, K. Suzumori, Y. Yagami (Department of Obstetrics and Gynecology, Nagoya City

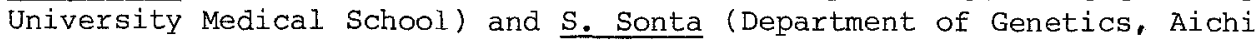
Prefectural Colony)

In cytogenetic studies in human congenital anomalies, researchers have often encountered chromosomally unbalanced cases derived from parents with reciprocal translocations. It is generally known that the frequency of patients with such abnormality derived from the mother defers from that from the father. As one of the causes, some authors have suggested a difference in the frequency of various class of cells from meiotic disjunctions. In the present study, we investigated the meiotic segregation ratio in male and female heterozygotes for the $t(1 ; 7)$ reciprocal translocation in the Chinese hamster. The results indicated that there was no difference in the frequency of cells from alternate, adjacent 1 , and adjacent 2 disjunctions between males and females. However, there was significant difference in the frequency of cells from 3 to 1 disjunction and cells with marker chromosomes resulted from crossing-over. These results suggested the possibility that in human cases there might be also a difference in the segregation ratio at primary meiosis between male and female heterozygotes for the some translocation. 
C 21

CROSSING-OVER ON THE INTERSTITIAL SEGMENTS AND THE FREQUENCY OF VARIOUS CLASSES OF MEIOTIC DISJUNCTIONS IN HETEROZYGOTES FOR RECIPROCAL TRANSLOCATIONS. Shin-ichi SONTA and Miho TSUKASAKI (Dept. Genet., Inst. Dev. Res., Aichi Pref. Colony, Kasugai)

Using male Chinese hamsters heterozygous for various reciprocal translocations, chromosomes of secondary spermatocytes were analyzed to investigate the frequency of crossing-over on the interstitial segments. In MII cells, unique marker chromosomes with unequallength chromatids were seen as a result of crossing-over on the interstitial segments. The results were as follows: (1) The frequency of crossing-over tended to be higher on longer interstitial segments than on shorter ones. (2) The frequency of crossing-over on the interstitial segment was similar to the frequency of crossing-over estimated by chiasma counts. The results revealed that the crossingover on each interstitial segment in translocated chromosomes might be controlled genetically just as in normal chromosomes. The identical chromosome constitution derives from alternate and adjacent 1 disjunction accompanying crossing-over on the interstitial segments in translocation heterozygotes. The results, therefore, suggest that we should not specify the origin of meiotic disjunctions in translocation heterozygotes only by mitotic karyotypes.

\section{22}

CHEMICAL (ANTINEOPLASTIC AGENTS)-INDUCED CHROMOSOME DAMAGE IN HUMAN SPERMATOZOA. Yujiroh KAMIGUCHI, Hiroyuki TATENO, Kazuya MIKAMO (Dept. Biol. Sci., Asahikawa Med. Col., Asahikawa) and Yoshiyuki IIZAWA (Dept. Obstet. Gynecol., Fukushima Med. Col., Fukushima)

We studied the cytogenetic effects of in vitro exposure of six antineoplastic agents, bleomycin (BM), cyclophosphamide (CP), daunomycin (DM), methyl methanesulfonate (MMS), mitomycin C (MMC) and triethylene melamine (TEM) on human spermatozoa. Total numbers of 2,055 and 2,368 spermatozoa were karyotyped in the control and the chemical-treated groups, respectively.

The incidences of spermatozoa with structural chromosome aberrations were $24.3 \%, 47.3 \%, 54.1 \%$ and $50.7 \%$ in BM $(50 \mu \mathrm{g} / \mathrm{ml}, 90 \mathrm{~min})$, DM (1 $\mu \mathrm{g} / \mathrm{ml}, 90 \mathrm{~min})$, MMS $(100 \mu \mathrm{g} / \mathrm{ml}, 120 \mathrm{~min})$ and TEM $(0.1 \mu \mathrm{g} / \mathrm{ml}, 120 \mathrm{~min})$ groups respectively, showing significantly higher incidences than those in matched controls (10.1-14.1\%). No significant increase of the incidence was found in CP $(1-1000 \mu \mathrm{g} / \mathrm{ml})$ and MMC $(0.1-100 \mu \mathrm{g} / \mathrm{ml})$ groups. Breakage-type aberrations were more frequent than exchangetype aberrations in BM, MMS and TEM, while the exchange-type aberrations were more frequent in DM. Exchanges were mainly of chromatid type in DM, MMS and TEM, while chromosome-type exchanges occurred more frequently in BM. These results were discussed in relation to our data on X-irradiated human spermatozoa. 


\section{23}

USE OF CRYOPRESERVED HAMSTER OOCYTES FOR HUMAN SPERM CHROMOSOME STUDY.

Hiroyuki TATENO, Yujiroh KAMIGUCHI, Kazuya MIKAMO (Dept. of Biol. Sci., Asahikawa Medical College, Asahikawa)

There are some merits of the use of frozen-thawed(FT) hamster oocytes for human sperm chromosome study. For example, there is no need to maintain a hamster colony, and the study can be performed in the clinics where experimental animals are prohibited to carry in. In this study, we described our freezing-thawing method which yields high rate of viable hamster oocytes, and examined its applicability to human sperm chromosome study. Survival rate of FT oocytes was more than $90 \%$, and they showed excellent performance comparable to freshly ovulated oocytes in both sperm penetration test and sperm chromosome analysis. No statistically significant difference was found in the spontaneous incidence of sperm chromosome aberrations between the assays with fresh and FT oocytes. It was also demonstrated that the use of FT oocytes caused no alteration on types and incidences of sperm chromosome aberrations induced by gamma-rays $(0.5$ and $2.0 \mathrm{~Gy})$ and daunomycin $(0.1$ $\mu \mathrm{g} / \mathrm{ml}$ ). In addition, female (hamster) pronuclei of FT ova showed no significant increase of chromosome aberrations, as compared with those of fresh ova. Thus, our freezing-thawing method was shown to be practically useful for human sperm chromosome study.

\section{24}

ANALYSIS OF HLA-DR TYPES IN JAPANESE SCHIZOPHRENICS BY PCR-GROUP SPECIFIC AMPLIFICATION

Tsukasa SASAKI, Xiao Y. DAI, Shin NANKO, Mineko HATTORI, Hajime KAZAMATSURI (Dept. Psychiatry, Teikyo Univ, Tokyo), Shoji KUWATA, Takeo JUJI (Dept.Transfusion Med. Immunohematology, Univ. of Tokyo) and Katsushi TOKUNAGA(Central Blood Transfusion Center, Japanese Red Cross, Tokyo)

In Japanese schizophrenics the association with HLA-DR8 and DRI (46\% and $22 \%$ in patients vs. 13\% and $10 \%$ in controls, respectively) was reported (Miyanaga 1984), but no further study has been made. We determined HLA-DR types by PCR-group specific amplification in 45 unrelated Japanese patients with schizophrenia or schizoaffective disorder (DSM-III-R). The frequency of DR types was compared with that in 51 unrelated healthy Japanese, which had been determined serologially and by PCR-SSOP. Tendency of the increase of DRl in 45 patients ( $22{ }^{\circ}$ in patients vs. 10 응 in controls, $p<0.1)$ and the significant increase of DR1 in female patients (33\% in 21 patients, $\mathrm{p}<0.05$ ) were observed. DRI was more frequent also in patients with auditory hallucination than in controls (33응 in 27 patients, $p<0.01$ ). In other DR types no differences were found between patients and controls. 
C 25

HLA-DR4 SUBTYPES OF JAPANESE, KOREAN AND CHINESE PATIENTS WITH INSULIN AUTOIMMUNE SYNDROME (HIRATA'S DISEASE)

Yasuko UCHIGATA, Shoji KUWATA, Katsushi TOKUNAGA, Makoto BANNAI, Takeo JUJI, Yasue OMORI

Diabetes Ctr, Tokyo Women's Med College, Dept Transfusion Med \& Immuno hematology, University of Tokyo, Jpn Red Cross Central Blood Ctr, Tokyo Metropolitan Blood Ctr.

We reported last year that all 20 Japanese patients with insulin autoimmune syndrome (IAS) so for examined had HLA-DRB $1 * 0406 / \mathrm{DQA} 1 * 0301 / \mathrm{DQB} 1 * 0302$. Another 17 Japanese patients, 2 Korean and 1 Chinese patients with IAS entered this HLA typing experiment. HLA class II genes were analysed by PCR-SSO method and reconfirmed by PCR-SSCP method and direct DNA sequence analysis. The 37 Japanese patients had a diversion of DR4 subtypes which consisted of $92 \%$ DRB 1*0406, 5\% DRB $1 * 0403$ and $3 \%$ DRB $1 * 0407$. All the DR4 subtypes had DQA $1 * 0301 / \mathrm{DQB} 1 * 0302$. 2 Korean and 1 Chinese patients had also DRB $1 * 0406 / D Q A 1 * 0301 / D Q B 1 * 0302$. The development of IAS is known to be more frequent in Japanese than in Caucasian. DRB $1 * 0406, \mathrm{DRB} 1 * 0407$ and DRB $1 * 0403$ were reported to be less frequent in Caucasian population. These differences explain that the development of IAS is less frequent in Caucasian. The region which is primarily associated with the development of IAS may be the DNA portion encoding amino acid (70-75) of DRB1, DQA1, or DQB1 locus.

\section{26}

DNA TYPING OF HLA CLASS II GENES IN DILATED CARDIOMYOPATHY Hirofumi NISHI ${ }^{12)}{ }^{2)}$, Akinori KIMURA ${ }^{2)}$, Haruhito HARADA $^{1) 2)}$, Yoshinori KOGA $^{1)}$, Hironori TOSHIMA ${ }^{1)}$, and Takehiko ${\underline{\text { SASAZUKI }^{2}}}^{2}$ 1)Third Dept. Int. Med., Kurume Univ., Kurume, 2)Dept. Genet., Med. Inst. Bioreg., Kyushu Univ., Fukuoka

To identify a genetic factor in the immune system that control the susceptibility to dilated cardiomyopathy (DCM), DNA typing of HLA class II genes (DRB, DQA, DQB, DPA, and $D P B$ ) was performed in 61 unrelated Japanese patients with DCM and 317 unrelated Japanese healthy controls by polymerase chain reaction in combination of dot-blot hybridization with 140 types of sequence-specific oligonucleotide probes, and frequencies of HLA class II alleles were compared. The frequency of DRB $1 * 1401$ (frequency in the patients versus that in the controls; $13 \%$ vs $4 \%, \mathrm{RR}=3.3, \chi^{2}=7.3$ ) was significantly increased in the patients. The DRB $1 * 1401$ is in linkage disequilibrium with the $\mathrm{DQB} 1 * 0503\left(15 \%\right.$ vs $5 \%$; $\left.\mathrm{RR}=3.06, \chi^{2}=7.19\right)$ that showed a positive association with DCM, and the frequency of DRB $1 * 1401-\mathrm{DQB} 1 * 0503$ haplotype was remarkably increased in the patient group ( $11 \%$ vs $\left.1.3 \%, \mathrm{RR}=10.4, \chi^{2}=15.5\right)$. Although an association with serologically defined HLA-DR4 antigen was reported in the Caucasoid populations, the frequency of DR 4 encoding DRB 1 alleles, i.e. DRB $1 * 0401(0 \%$ vs $4.4 \%), * 0403(3.3 \%$ vs $3.8 \%), * 0405(32.8 \%$ vs $27.8 \%), * 0406(3.3 \%$ vs $5.0 \%)$, $* 0407(1.6 \%$ vs $0.3 \%)$, and $* 0410(3.3 \%$ vs $2.8 \%)$ was not significantly changed in the Japanese patients. These observations suggest that HLA-DR and DQ loci may control the susceptibility to DCM. 
DIFFERENCE IN HLA-LINKED GENETIC BACKGROUND BETWEEN MCTD AND SLE Rui-Ping DONG ${ }^{1)}$, Akinori KIMURA ${ }^{1)}$, Hiroshi HASHIMOTO $^{2)}$, Masashi AKIZUK| ${ }^{3)}$, Yasuharu NISHIMURA ${ }^{4)}$, and Takehiko SASAZUKI $^{1)}$ 1)Dept. Genet., Med. Inst. Bioreg., Kyushu Univ., 2) Div. Rheumatol., Juntendo Univ., 3) Dept. Internal Med., Keio Univ., 4) Div. Immunogenet, Kumamoto Univ.

We have typed 64 Japanese patients with mixed connective tissue disease (MCTD) and 53 Japanese patients with systemic lupus erythematosus (SLE) for HLA class II genes by the HLA-DNA typing method. Frequencies of HLA$\mathrm{DRB} 1{ }^{*} 0401, \mathrm{DRB} 4^{*} 0101$, and $\mathrm{DQA1}{ }^{*} 03$ were increased in the patients with MCTD, while the frequencies of HLA-DRB1*1501, DRB5*0101, and DQB1*0602 were increased in the patients with SLE. The typing results suggest that the susceptibility to MCTD is strongly associated with the HLADRB1*0401-DRB4*0101-DQA1*03-DQB1*0301 haplotype, and that to SLE is associated with the HLA-DRB1*1501-DRB5*0101-DQA1*0102-DQB1*0602 haplotype. It was observed that the frequency of MCTD-associated HLA class II alleles was not increased even in the DRB1*1501 negative patients with SLE and that the frequency of SLE-associated HLA class II alleles was not increased in the DRB $1^{*} 0401$ negative patients with MCTD. The observation that the MCTD-associated HLA alleles are distinct from the SLE-associated ones may support the clinical entity of MCTD different from SLE.

\section{28}

DIFFERENCES IN THE BINDING AFFINITY OF HLA_DR4 SUBTYPE WITH FOREIGN PEPTIDES.

TOIDA NOZOMU KAMIKAWAJI NOBUHIRO TOU SUIHEI FUJITA YUKARI SASAZUKI TAKEHIKO

MEDICAL INSTITUTE OF BIOREGULATION KYUSHU UNIVERSITY

HLA classII molecules (HLA_DR,DQ,DP) are highly polymorphic glycoproteins composed of $\alpha$-and $\beta$-chains. The polymorphism is found in the extra-cellular domein, especially at the amino acid residnes contacting with antigen-peptides and $T$-cell receptors.To clarity the differences in the binding affinity to foreign peptides between locus-and allele-specific HLA class II molecules, we have established a fluoreiscein mediated measurement system of the peptide-binding. L-cell transfectants expressing different HLA class II molecules were incubated with biotinilated syuthetor peptides derived from a Streptococcal $M$ protein. The binding of the peptides was measured by using FACScan after the transfectants were incubated with Avidin-PE. The assay system demonstrated that the binding of peptides to HLA class II molecule was dose-dependent and dependng on the expression of the HLA molecules. It was also found that the binding affinity of peptides was greatly influenced by the amino acid changes,including one amino acid change. Therefore the polymorphism in HLA classII genes was confirmed to be responsible for the different binding affinity of foreign peptides by the molecule. 
C 29

IMMUNORESPONSE IN POSTSTREPTOCOCCAL ACUTE GLOMERULONEPHRITIS. Kazuhiro MORI, Nobuhiro KAMIKAWAJI, Akinori KIMURA and Takehiko SASAZUKI (Dept., Genet., Med., Inst., Bioreg., Kyushu Univ., Fukuoka)

Thirty-five patients with poststreptcoccal acute glomerulonephritis (PSAGN) were typed for HLA class II genes by PCR-Sequence Specific Oligonucleotide (SSO) method. The frequencies of DRBI*1502 ( $9 \%$ vs $25 \% ; \quad R R=0.28, x^{2}=3.89$ ) and DPB1*0201 ( $14 \%$ vs $32 \%$; $R R=0.35, x^{2}=3.91$ ) were significantly decreased and that of DPBI*0501 ( $83 \%$ vs $61 \%$; RR $=3.0$ $6, \mathrm{x}^{2}=6.33$ ) was significantly increased. Ig $G$ antibody titer against $C$ region of $M$ protein was significantly higher in PSAGN than that of normal control (52480 LU vs

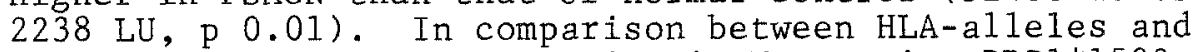
immunoresponse against C-region in M protein, DRB1*1502 and DRB1*0803 were correlated to the high immuno-response, and DRB1*1501 and $* 0802$ to the low response.

\section{30}

Analysis of The binding of Peptides derived from Streptococcal Mprotein to HLA molecules and Their $T$ cell stimulating activity

Nobuhiro KAMIKAWA.J. Yukari EUJITA. Rui-Ping DONG. Nozomi TOIDA, Kazuhiro MORI. Tohru SUDOH, and Takehiko SASAZUKI,

Department of Genetics,Medical Institute of Bioregulation,Kyushu University,Fukuoka.

HLA molecules bind with antigenic peptides and present them to T cells. It is considered that the immune responsiveness to antigenic peptides is deternined, in some parts, by the binding affinity between HLA molecules and the peptides. In this study, we compared the T cell response to the M12 peptides and the binding affinity of M12peptides with HLA molecules. We found $M 12(347-367)$ was a dominant $T$ cell epitope which was presented by HLA-DQw6. The binding affinity of M12(347-367)with HLA-DQw6 was stronger than that of other peptides derived from M12 protein.Among six HLA-classll molecules (DR2(DRB1*1502),DRw51(DRB5*0102), DQw6(DQA1*0103/DQB1*0601),DR4(DRB1*0405) , DRw53(DRB4*0101),DQw4(DQA1*0301/DQb1*0401)), binding affinity of HLA-DQw6 with $M 12(347-367)$ was the strongest, and M12(347-367) activated T cells restricted by HLA-DQw6 selectively. No HLA-DQw4 restricted T cell response specific for Streptococcal cell wall antigen (a crude extract of M12 protein) was observed, though there were peptides those bind with HLA-DQw4 as well as M12(347-367) with HLA-DQw6. Thus, besides the binding of antigenic peptide with HLA molecules, there should be existed some other conditions for activation of T cell by peptides-HLA complexes. 
C 31

\author{
PURIFICATION OF A SOLUBLE FACTOR FOR CYTOTOXIC \\ ACTIVITY THAT INDUCES A LOW IMMUNE RESPONSE TO \\ STREPTOCOCCAL CELL WALL ANTIGEN. Hideyuki \\ YOSHIZUMI, Nobuhiro KAMIKAWAJI, Takehiko SASAZUKI \\ (Dept. of Genetics, Med. Inst. of Bioreg., Kyushu Univ.)
}

We previously reported that autoreactive $\mathrm{CD} 8^{+} \mathrm{T}$ cells obtained from a low responder to streptococcal cell wall antigen (SCW) lysed antigen presenting cells in the context of HLA-B molecules, resulting in a low level immune response to $\mathrm{SCW}$. The cytotoxic activity of the $\mathrm{CD} 8+\mathrm{T}$ cells was only observed in the presence of a soluble factor from cultured peripheral blood lymphocytes. We, subsequently, purified the factor by means of adsorption with activated charcoal and reversed-phase HPLC. The activity of the soluble factor for cytotoxic activity (SFCA) was found in one fraction of the eluents.

C 32

\author{
ANALYSIS OF HLA-B GENE POLYMORPHISM BY PCR GROUP \\ SPECIFIC AMPLIFICATION. \\ Shoji KUWATA, Masami YANAGISAWA, Takeo JUJI (Dept. \\ Transfusion Med.\& Immunohematol., Univ. of Tokyo, Tokyo) and \\ Katsushi TOKUNAGA (Dept. Research, Jpn. Red Cross Central Blood \\ center, Tokyo)
}

We performed group specific amplification of HLA-B gene by polymerase chain reaction. Three regions of HLA-B gene were examined using genomic DNA; 1) B4- or B6- associated group specific amplification of exon 2 of HLA-B gene, 2) B51 or B52 group specific amplification spanning exon 2 , intron 2 and exon 3 of HLA-B gene, 3) B51 or B52 group specific amplification of exon 2 of HLA-B gene. We verified 7 individuals with B51, 11 with B52 and 2 with B51/B52. All the attainments were successful and the group specificity were also confirmed. Analysis of HLA class I gene will provide further insights on the genetic, evolution, and disease study. 


\section{33}

Association Between HLA-B67 and Subacute Thyroiditis, and Comparison of Clinical Feature Between B35 and B67 Positive Patients

Tohru SUDOH, Akinori KIMURA. Hajime TAMAI, Kanji KUMA. Ryoko OHKUBO, Yasuharu NISHIMURA, and Takehiko SASAZUKI.

Department of Genetics,Medical Institute of Bioregulation,Kyushu University,Fukuoka.

Subacute thyroiditis has been reported to have strong association with HLA-B35 and is thought to be caused by cytopathic viruses.For further study, we examined HLA and clinical feature of 56patients with subacute thyroiditis, and acquired the foliowing conclusions as 1 . Patients with subacute thyroiditis had statistically significant increased frequency of HLA-B67 $\left(16 \%\right.$ vs $2 \%$, R.R. $=15.68, \chi^{2}=18.94$, PC $\left.<0.01\right)$ as well as HLA-B35 $(75 \%$ vs $12 \%$, R.R. $=18.2, \chi^{2}=88.59, \mathrm{PC}<0.001$ ) compared with 238 healthy controls. And no heterozygotes of $B 35$ and $B 67$ were found in 56 patients. This strong association was clarified with DNAtyping of HLA-B genes. 2. HLA-B67 positive patients had clinical characteristics with increased onset from summer to autumn, and tendency to fall into hypothyroidism.It thus appeard that B67 positive subacute thyroiditis is caused by specific virus and different pathogenesis from B35 positive subacute thyroiditis.

\section{34}

HLA-LINKED SUSCEPTIBILITY TO PSORIATIC ARTHRITIS AND PRODUCTION OF TUMOR NECROSIS FACTOR- $\alpha$. Masahiko MUTO, YOshiaki HAMAMOTO and Chidori ASAGAMI (Dept. Dermatol., Yamaguchi University School of Medicine, Ube)

We report on the production of tumor necrosis factor- $\alpha$ (TNF- $\alpha$ ) by streptococcal-antigen-activated peripheral blood mononuclear cells from HLA-typed Japanese patients with psoriatic arthritis(PA). The results indicate that a correlation between TNF- $\alpha$ in vivo levels and HLA was not found in PA. In vitro production of TNF- $\alpha$ was induced by streptococcal antigen. There was no correlation between high production of TNF- $\alpha$ and HLA-A2, whereas a non-HLA-A2 PA patient showed low level of TNF- $\alpha$ inducibility. These data show possible regulations of TNF- $\alpha$ in vitro production by HLA. 


\section{35}

EPSTE IN-BARR VIRUS BCRF1 GENE PRODUCT(VIRAL INTERLEUKIN 10 )INHIBITS SUPEROXIDE ANION PRODUCTION BY HUMAN MONOCYTES. Hiroaki NIIRO, Takeshi OTSUKA.

Hironobu SATOH, Tomonori OGO. Teruaki NAKANO, Yuko FURUKAWA. Yoshiyuki NIHO (The First Dept. Int. Med., Kyushu Univ., Fukuoka) and Masayoshi ABE(Res. Inst. for Dis. of the Chest, Kyushu Univ., Fukuoka)

Due to its similar biological activities to interleukin $10($ IL-10), Epstein-Barr virus(EBV) BCRF1 gene product( viral IL-10: vIL-10) has recently been recognized as an analogue of authentic IL-10. Preincubation of human monocytes with vIL-10, like human IL-10, induced smaller amounts of interferon- $\gamma(I F N-\gamma)$ mRNA in activated human peripheral blood mononuclear cells (PBMNCs) than nonpreincubation, indicating that vIL-10 acts principally on monocytes. Since the activation of monocytes and their generation of oxidative products are regulated by various cytokines, we examined the effects of vIL-10 on superoxide anion $\left(\mathrm{O}_{2}^{-}\right)$production by human PBMNCs and monocytes. Not only PBMNCs, but also monocytes preincubated with vIL-10, showed a smaller production of $\mathrm{O}_{2}{ }^{-}$. Inhibition was achieved in a dose-dependent fashion and reached a maximum level $9 \mathrm{hr}$ after incubation with vIL-10. Additions of IFN- $\gamma$, granulocyte colonystimulating factor (GM-CSF) or macrophage colony-stimulating factor (M-CSF). Which prime monocyte activation and induce $\mathrm{O}_{2}{ }^{-}$production, were also affected by the reciprocal effect of viL-10. Thus, vIL-10 production by EBV-infected cells may be involved in the development of EBV-related disorders.

\section{36}

Effect of interleikin-10 on the superoxide anion $\left(\mathrm{O}_{2}^{-}\right)$production of human peripheral blood mononuclear cells: Analysis in healthy volunteers and patients of autoimmune diseases. Takeshi OTSUKA. Hiroaki NIIRO. Teruaki NAKANO, Tomonori OGO, Seiii KUGA, Yoshiyuki NIHO (The First Dept. of Interman Medicine, Kyushu University, Fukuoka)

It is suggested that relationship between type I and type II helper $T$ cells affects the direction of subsequent immune responses. Based on the results of Niiro et al as described above, we examined the effect of interleukin-10 (IL10) on the $\mathrm{O}_{2}$ - production of peripheral blood mononuclear cells (PBMNCs) isolated from healthy volunteers or patients of autoimmune diseases.

As a result, the $\mathrm{O}_{2}$ - production of human PBMNCs was suppressed by $\mathrm{IL}-10$ in some individuals, however it was rather induced in other individuals. Rates of suppression or induction indicated a broad spectrum, suggesting that PBMNCs of each individual responded differently to IL-10. In rheumatoid arthritis, suppression of the $\mathrm{O}_{2}^{-}$production by $\mathrm{IL}-10$ was significant in active stage, and then became less after steroid treatment. On the other hand, the $\mathrm{O}_{2}$ - production was rather induced by $\mathrm{LL}-10$ in active stage of systemic lupus erythematosus. 
C 37

BREAKPOINTS OF RECIPROCAL TRANSLOCATION CHROMOSOMES IN MAN (2). Hidetsune OISHI (Dept. Genet., Inst. Develop. Res., Aichi Pref. Colons, Kasugai) and Takashi YamanAKA (Cent. Hosp., Aichi Pref. Colony, Kasugai)

Familial reciprocal translocations ascertained for the birth of malformed children were collected from our record and published papers. Of 545 families examined, unbalanced chromosomes of probands in 407 cases were produced by adjacent-1, 16 cases by adjacent- 2 and 122 cases by $3: 1$ segregation. All but 5 trisomy segments by the adj-2 were derived from acrocentrics or no. 9 chromosomes and all monosomy from the former. By the 3:1 segregation, 23 of 112 trisomy segments were consisted of a combination of $t(11 ; 22)$, and monosomy in 10 cases. Relative lengths of partial monosomy-trisomy by the adj-2 were measured 2.41 (as $\%$ of total haploid autosome length) in average, ranged 0.73 to 4.73 , while these of monosomy and trisomy by the $3: 1$ were recorded 1.05 , ranged 0.08 to 1.58 , and $1.83,0.46$ to 5.08 , respctively. All of these values were similar to those of the adj-1. In the adj-2 group mother and father with balanced conditions were 12 and 4 , respectively, meantime the mother in the $3: 1$ were 109 out of 122 balanced parents. From these data it was postulated that the excess of mothers were mainly originated from progeny by abnormal eggs, and that most of sperms with unbalanced conditions were selected during the course of fertilization.

\section{38}

DIAGNOSIS OF CYTOLOGICALLY UNIDENTIFIABLE CHROMOSOME ABNORMALITIES WITH MICRODISSECTION-CHRONOSOME PAINTING METHOD. Tohru OHTA, Nor io NIIKAWA (Dept. Hum. Genet., Nagasaki Univ. Sch. Med., Nagasaki), Takaya TOHMA (Dept. Pediatr., Fac. Med., Univ. Ryukyus, Okinawa), Toshiro NAGAI (Dept. Pediatr., Kiyose Metropol. Child. Hosp., Tokyo), Yoshimitu FUKUSHIMA (Div. Med. Genet., Saitama Child. Med. Ctr., Iwatsuki)

We report an application of the microdissection-chromosome painting method to the diagnosis of chromosome abnormalities which had not been identified with any banding methods. An excess segment of each abnormal chromosome in five patients was microdissected, and PCR-amplified DNA from the segment was biotin-labeled and used as a probe pool for fluorescence in situ suppression hybridization (FISH). FISH signals were detected with FITC-conjugated avidin. A probe pool from an excess segment of $9 p+$ in a patient gave FISH-signals on both $9 p$ and $12 p$ in the metaphase cells of both the patient and a normal person. This indicated that the patient has partial trisomy for 12pter-p12. Likewise, a patient with $17 \mathrm{p}$ + has partial trisomy for $14 \mathrm{q} 32$-qter, a patient with $6 \mathrm{p}+\mathrm{a}$ tandem duplication of $6 \mathrm{p} 23-21.33$ segment, a patient with $6 \mathrm{q}+$ a duplication of a 6q24-qter segment, and the other patient with +mar has tetrasomy for 18pter-p11. The present chromosome painting is a rapid and reliable method to diagnose cytogenetically unidentifiable aberrations. 
CHARACTERIZATION OF MICROCOLONS AND COSWID CLONES FROM MICRODISSECTED CHROMOSOMAL G-DARK AND G-LIGHT BANDS. Koh-ichiro YOSHIURA, Norio NIIKAWA, Yoshihiro JINNO (Dept. Hum. Genet., Nagasaki Univ. Sch. Med., Nagasaki)

The human genome does not show uniformity in GC content, gene distribution and in repetitive sequence constitution. We isolated a number of microclones and cosmid clones directly from G-positive and negative band regions of a chromosome by the use of microdissection, and analyzed $\mathrm{GC}$ and/or $\mathrm{Alu}$ repeat contents in the clones in order to characterize the DNA in both bands. A G-positive band region, 11q14-q22, and a negative band, 11q23-qter, were microdissected, and band-specific DNA libraries were constructed. A total of 60 microclones containing Alu sequences and 64 single-copy clones were isolated and all sequenced. Twenty-eight of the 29 G-positive band-derived clones, 30 of the $34 \mathrm{G}$ negative band-derived clones were independent. No difference of GC contents was seen between the clones from the two bands. Class IV Alu sequences were frequently observed in the DNA from the G-negative band. Five cosmid clones corresponding to the microclones were isolated and mapped to the dissected regions by the use of fluorescence in situ suppression hybridization.

C 40

DiGeorge syndrome with del(4)(q21.3q25): Possibility of the fourth chromosome region responsible for DiGeorge syndrome. Y. Fukushima, H. Ohashi, K. Wakui, T. Nishida, Y. Nakamura, K. Hoshino. K. Ogawa, and T. Oh-ishi (Saitama Children's Medical Center, Iwatsuki, Saitama)

A female newborn patient was complicated with following multiple anomalies: Congenital heart disease including interruption of aorta, VSD, ASD, and PDA, hypoplasia of corpus callosum, peculiar facies such as sparse hair, wide metopic suture, low nasal bridge, short nose, low-set and malformed ears, high arched and narrow palate and micrognathia. She was complicated with cellular immunodeficiency including thymic hypoplasia and decreased T-cell population, and hypoparathyroidism. Chromosome analysis was successfully performed by using B-lymphoblastoid cell-line. The karyotype was $46, \mathrm{XX}, \mathrm{del}(4)(\mathrm{q} 21.3 \mathrm{q} 25)$. DiGeorge syndrome (DGS) is a heterogenous developmental field defect. This patient has typical features of DGS and indicates that $4 \mathrm{q} 21.3-\mathrm{q} 25$ is the fourth chromosome region responsible for DGS, following 22q11, 10p13 and 17p13. 


\section{41}

MOLECULAR STUDY IN A PATIENT WITH CRANIOSYNOSTOSIS AND A DE NOVO $t(6 ; 7)$ TRANSLOCATION. Kazushiro TSUJI, Kouji NARAHARA, Shinsuke NINOMIYA, Yuji YOKOYAMA, Masae MURAKAMI, Yosiki SEINO (Dept. Pediatr., Okayama University Medical School, Okayama)

Craniosynostosis (CRS) is often seen in the $7 \mathrm{p}-$ syndrome, and the gene for CRS1 has been assigned to 7p21 (HGM 11). We saw a 3-year-old boy with many minor anomalies, including craniosynostosis involving sagittal and coronal sutures, narrow forehead, narrow palpebral fissure, antimongoloid slant, long cilia, anteverted nostrils, low set and cupped ears, high arched palate and fusion of upper incisors. Mild developmental delay was also found. Chromosome analysis showed a karyotype of $46, X Y, t(6 ; 7)(q 16.2 ; p 15.3)$ de novo. On the assumption that the cranial anomaly in this patient is thought to have been caused by the rearrangement within the CRS1 gene, Southern blot analysis using DNA probes located on $7 \mathrm{p}$ was done. The patient was heterozygous for homeo box II (c2A/4.3) locus, interleukin 6 (pbeta2.15) locus and D7S149 (TS93) locus, whereas hemizygous for D7S135 (TM102L). These results suggested that the candidate gene of CRS1 may be neighboring D7S135.

\section{42}

Klippel-Feil syndrome and a de novo balanced autosomal translocation $[46, X X, t(5 ; 17)(q 11.2 ; q 23)] . K$. Wakui. $H$. Ohashi. H. Nishimoto. M. Sato. T. Aihara, T. Nishida, Y. Fukushima (Saitama Children's Medical Center, Iwatsuki, Saitama)

A 6-year-old girl presented following anomalies: midfacial hypoplasia with a low nasal root, a short nasal septum, a long philtrum, a thin upper lip, micrognathia, a low posterior hair line, a short and wide neck, brachydactyly, hypoplastic nails, and pes planus. Radiological examination revealed spinal abnormalities including fusion of $\mathrm{C} 5-\mathrm{C} 7$, a flat $\mathrm{C} 4$ body, a narrow interspace between Th5 and Th6 and a wide spinal canal at C4-Th1, and brachydacty1y. Her psychosomatic development was normal. Chromosome analysis revealed a de novo balanced reciprocal translocation $[46, \mathrm{XX}, \mathrm{t}(5 ; 17)(\mathrm{q} 11.2 ; \mathrm{q} 23)]$.

The pattern of abnormalities in this patient appears to represent a subtype of KFS with additional features such as brachydactyly and characteristic facies. We postulate that at least one of the genes responsible for KFS is located at $5 \mathrm{q} 11.2$ or $17 \mathrm{q} 23$ involved in the translocation. 


\section{43}

ABSENCE OF SHORT STATURE, CHONDRODYSPLASIA PUNCTATA AND MENTAL RETARDATION IN TWO BOYS WITH INTERSTITIAL DELETIONS OF THE XP22.3 REGION Makoto YOSHINO, Terahiro KAWANO, Shigeru KARUKAYA, Etsuo OHTAKI, Osamu INOUE, Hirohisa KATO (Dept. Pediatr. \& Child Health, Karwne Univ., Kurnme), Hiroshi SHIMIZU, Minorn OHSAKI, Takahiko MATSUMOTO, Shin-ichiro NISHIMURA, Nobuo SAKURA (Dept. Pediatr., Hiroshima Univ., Hiroshima), Fumiko SAITOH, Tatsuro IKEUCHI (Dept. Cytogenet., Tokyo Med. Dent. Univ., Tokyo)

Correlation between clinical manifestations and deletions of DNA markers in Xp22.3 region are examined in two boys having ichthyosis with steroid sulfatase (STS) deficiency. Patient 1 had ichthyosis with STS deficiency (XLI), but short stature (SS), chondroysplasia punctata (XRCDP), mental retardation (MRX) and the signs of Kallmann syndrome (KAL) were absent. The STS locus was deleted, but the other loci tested were preserved. Patient 2 had epilepsy and XLI, but exhibited no signs of SS, XRCDP, MRX and KAL. The MIC2 and DXS143 loci were present, but the DXS31, STS and DXS89 loci were deleted. There was no evidence of microscopic deletion in this region in either patients. These results suggest that the MRX locus is located proximal to DXS31 loci or the the MRX can be present with very wide clinical spectrum.

\section{44}

3 CASES WITH "LACK OF X-INACTIVATION SYNDROME". Satoshi ISHIKIRIYAMA, Nozomu SASAKI, Mizue IAI, Yuzo TANABE (Chiba Children's Hospital, Chiba) and Hirofumi OHASHI, Yoshimitsu FUKUSHIMA (Saitama Children's Medical Center, Saitama)

We saw 2 cases with $r(X)$ mosaicism and a case with unbalanced X-autosome translocation mosaicism. All of the 3 cases were suffering from mental retardation and variable anomalies, but not from symptoms associated with Turner syndrome. The sets of anomalies were quite different among the cases. The karyotypes were $45, X / 46, X, r(X)(p 11 q 11)$, $45, X / 46, X, r(X)(p 22.1 q 13), \quad 45, X, \operatorname{der}(21) \mathrm{t}(\mathrm{X} ; 21)(\mathrm{p} 22.1 ; \mathrm{p} 11.2) / 46, \mathrm{X}, \mathrm{t}(\mathrm{X} ; 21)$ (p22.1;p11.2), respectively, and the mosaic ratios on $\mathrm{PHA}-$ stimulated peripheral lymphocytes were $82 \%, 13 \%, 69 \%$, respectively. On analysis of replication patterns on cells with the karyotypes; $46, X, r(X)$ and $45, X, \operatorname{der}(21) t(X ; 21)$, none of normal $X, r(X)$ and der(21) were late-replicated. One of two $X$-inactivation centers (XIC) located at Xq13.3 might be lost in these cells, so we considered these cases "lack of X-inactivation syndrome", which Grompe et al. (1992) proposed. Differences both in mosaic ratios and in breakpoints might explain the clinical variety among the cases. 
C 45

TISSUE SPECIFICITY AND MOSAICISM IN PALLISTER-KILLIAN +i(12p) SYNOROME IN TWO FETAL CASES. Mashio KITATANI, Mamoru OZAKI, Hiroaki TAKAHASHI (Clinical Genetics, Human Genetics, Medical Research Institute, Kanazawa Medical University, Ishikawa)

We ascertained $+\mathrm{i}(12 \mathrm{p})$ mosaicism during third trimester in two cases of diaphragmatic hernia diagnosed by ultrasound examination. In case 1 , primary cultures of amniocytes had $6 \% 46, X Y / 94 \% 47, X Y,+i(12 p)$ in cells at 25 weeks gestation. Spontaneous delivery was at 30 weeks with immediate death. In addition to the characteristic phenotype, this patient had diaphragmatic hernia, shortening of fumeri and femora, and imperforate anus. $11 \%$ of metaphase from a cord blood culture vere $i(12 p)$ positive while $100 \%$ of metaphase from a skin fibroblast culture were i(12p) positive. In case 2 , primary cultures of amniocytes had $72 \%$ $46, X Y / 28 \% 47, X Y,+i(12 p)$ in clolnies at 33 weeks gestation.

Prenatally cytogenetic studies should be considered in all cases of diaphragmatic hernia associated with other malformations. This is important in counselling, as the recurrence risk for Palliser-killian syndrome is negligible.

\section{46}

SEGREGATION ANALYSIS OF FFAMILIAL CASES WITH MOYANOYA DISEASE. KiyOShi IMAIZUMI, Kenj i KUROSAWA, Mitsuo MASUNO, Yoshikazu KUROKI(Div.Med.Genet., Kanagawa Children s Medical Center, Kanagawa)

The etiology of moyamoya disease remains speculative. Fukuyama et al reported in their epidemiological study that the famlial incidence was $7.5 \%$ among Japanese patients and concluded the moyamoya disease was multifactorial inheritance. We reported the segregation analys is of 19 familial cases including 2 present cases with moyamoya disease. In case 1 mother and son were affected and affected two siblings in case 2 . Sex ratio of male to female was $1: 1.5$. The segregation rate and its standard error was $0.192 \pm 0.03$ by single incomplete ascertaiment method and was $0.333 \pm 0.06$ by single method. There were affected 3 families with monozygotic twins and one dizygotic twins. Four families with affected parents and their children were reported. These results suppose that the moyamoya disease may have hetrerogeneous group and some of them may inherit as an autosoma dominant trait. As diagnosis of the moyamoya disease mainly depends on carotid angiography, it makes difficult to examine family member. MRI angilgraphy may be a powerfull technique to detect carrier patients and they may become clear its inheritance. 
C 47

\section{A GENETIC SURVEY OF A GROUP OF CHILDREN WITH CLEFTING: IMPLICATIONS FOR GENETIC COUNSELING \\ Y.HOFSTEE (Streekziekenhuis Midden-Twente, Hengelo, the Netherlands), N.KORS \\ (Streekziekenhuis Midden-Twente and Victor Veau Foundation, Hengelo, the Netherlands), \\ R.C.M.HENNEKAM (Clinical Genetics Center Utrecht, Utrecht, the Netherlands)}

A cleft lip, cleft palate or both were reported in several studies to be associated with other anomalies in high frequencies. This study gives an inventarisation of such associaled anomalies in a consecutive group of children $(n=37)$ with clefts referred to a local multidisciplinary schisisteam in the Netherlands. In $48.6 \%$ associated anomalies were found leading to a strong suspicion or establishment of a covering entity. In eighteen patients family history was positive for a clefting disorder; in 5 of them (13.5\%) this had influence on the recurrence risks for siblings. Both findings had a large impact on genetic counseling of the parents of these children. The results of this study provide additional evidence that all children with a clefting disorder should be carefully evaluated for additional anomalies, including a search for dysmorphic features by a trained clinician.

\section{48}

CHILDHOOD MALIGNANCIES ASSOCIATED WITH CONGENITAL ABNORMALITIES. Ichiro MATSUl, Masako TANIMURA (Dept. Child Ecology, Nat'1 Children's Med. Res. Center, Tokyo), Noboru KOBAYASHI (Nat'l Children's Hospital, Tokyo), Tadashi SAWADA (Dept. Pediat., Kyoto Pref. Univ. Hosp., Kyoto), Jun-ichi AKATSUKA (Dept. Pediat., Jikei Univ. Hosp., Tokyo), and Kozo HASHIZUME (Dept. Pediat. Surgery, Univ. Tokyo Hosp., Tokyo)

Some 445 cancer cases $(5.9 \%)$ associated with various types of congenital abnormality among 7,509 children were entered in the Japan Children's Cancer Registry between 1986-1990. Of 96 cancer cases with chromosomal abnormalities, 69 were associated with Down syndrome, including 61 acute leukemias, 6 teratomas, 1 hepatoblastoma and 1 neurinoma, $513 q^{-}$with retinoblastoma, and $411 \mathrm{p}^{-}$with Wilms tumor;2 XXY, $2 \mathrm{XO} / \mathrm{XY}$, and 14 others wereassociated with various childhood cancers. Of 45 cancers with single gene defects, 35 neurofibromatosis type 1 cases occurred in optic gliomas, brain tumors, malignant schwannomas, as well as acute myelogenous leukemias, genitourinary rhabdomyosarcomas, and other cancers. Three ataxia telangiectasias associated with 2 ALL and a malignant lymphoma, 2 tuberous sclerosis with a brain tumor and a kidney cancer, 2 DMD with an ALL and a rhabdomyosarcoma, 2 MEN syndrome with endocrine malignancies, 1 Fanconi's anemia with AML and 1 hemophilia-A. with a brain tumor. Fourty-one cancer cases associated with multiple malformations (including several syndromes) and 263 with single organic malformations. A possible new syndromic association of AML with congenital defects was discussed. 


\section{49}

THE ELEVATION OF CIRCULATING IMMUNE COMPLEX LEVELS EITHER C1q-, C3d-CIC IN DOWNS SYNDROME. Ryuichi TSUKINO, Mitsuyo MUKAI (Dept. Pediat., Wakayama Medical college, WAKAYAMA)

Ninety subjects with Downs syndrome aged 11 days to 19 years old were assayed their circulating immune complex (CIC) either C1q-, C3d-CIC and the following results were obtained: 1 The positive rate and their mean \pm SD of C1q, $\mathrm{C} 3 \mathrm{~d}-\mathrm{CIC}$ were $85.6 \%$ and $85.3 \pm 40.2 \mu \mathrm{g} / \mathrm{ml}$ and $91.0 \%$ and $59.0 \pm 30.7 \mu \mathrm{g} / \mathrm{ml}$ respectively. 2 The positive rate of autoantibodies either anti-ANA, -DNA, RAHA or RF were $28 \%$ and the levels of CIC either C1q-, C3d-CIC were $126.6 \pm$ $42.2 \mu \mathrm{g} / \mathrm{ml}$ and $103.8 \pm 35.3 \mu \mathrm{g} / \mathrm{ml}$ in the autoantibody positive group $(\mathrm{n}=12)$ and $92.4 \pm 33.9 \mu \mathrm{g} / \mathrm{ml}$ and $71.4 \pm 24.4 \mu \mathrm{g} / \mathrm{ml}$ in negative group $(\mathrm{n}=32)$ but these were not significant. 3 There were no significant relationship between $\mathrm{CIC}$ and age or existence of malignancy, infections and liver disturbances. 4 The levels of complement $\mathrm{C} 3, \mathrm{C} 4$ and $\mathrm{CH} 50$ were negatively proportional to $\mathrm{CIC}$ except $\mathrm{C} 3$ between $\mathrm{C} 3 \mathrm{~d}-\mathrm{CIC}$. 5 Positive relationship was observed between the levels of $\mathrm{C} 1 \mathrm{q}$ and $\mathrm{C} 3 \mathrm{~d}-\mathrm{CIC}$.

\section{50}

12 CASES OF NEONATAL VESICOURETERAL REFLUXX DETECTED BY ULTRASOUND SCREENING OF NEWBORN INFANTS FOR KIDNEY AND URINARY TRACT ABNORMALITIES. Akira MATSUI I) Michiko AOKI 7 ) Shozo MAEDA I) Tsunehisa TAKENAKA2) (Dept. Pediat!) and Obstet \& Gynecol.,2) Isesaki Municipal Hospital, Gunma), Masamichi HAYASHI, Hidetoshi YAMANAKA (Dept. Urol., Gunma University, Gunma)

Out of 2,257 newborn infants in which ultrasound screening of kidney and urinary tract abnormalities was performed, 12 $(0.53 \%)$ were found to have vesicoureteral reflux(VUR). The VUR was unilateralin 6 cases ( 6 renal units) and bilateral in 6 (12 renal units). Clinical and laboratory findings of these 12 cases ( 9 males, 3 females) were investigated. Dilatation of the renal pelvis was observed in 6 cases $(9$ renal units) and brightly echogenic renal pyramids were found in 2 cases (4 renal units). Grade II VUR was found in 6 renal units, grade III in 4 and grade $I V$ in 7 . In one case VUR grade could not be assessed. 4 cases (33.3\%) had coexistent congenital anomalies. Bacteriuria was found in 9 cases and episodes of urinary tract infection were observed in 7 cases. Surgical correction was performed in 6 cases. Spontaneous cessation of reflux was confirmed in 2 cases. 
C 51

SOTOS SYNDROME: CHRONOLOGICAL CHANGE OF FACIAL APPEARANCE. Masato TSUKAHARA, Tadashi KAJII( Dept. Pediatr. Yamaguchi Univ. Sch. Med., Yamaguchi)

Six infants with Sotos syndrome, four boys and two girls of ages 8 days to 3.5 years, were followed up for 11 months to 8 years (average 4 years) with an interval of 6-12 months, in order to observe changes with age of craniofacial manifestations of the syndrome. The facial manifestations of the syndrome were less characteristic in the neonatal period to early infancy than in early childhood( $18-24$ months ), when they became obvious. Anthropometric measurements of craniofacial landmarks also supported the finding.

C 52

AN ANALYSIS OF PLURAL BIRTH WEIGHT IN JAPAN. 1. Birth weight according to the category of plural births. Akio ASAKA (Yamanashi Medical University) and Noriko KATO (National Institute of Public Health)

We performed an analysis of plural birth weight among 50,700 individuals, who were live-born during 1988-1990 all over Japan. The mean birth weight was $2393 \mathrm{~g}$ for twins $(\mathrm{n}=49,223), 1781 \mathrm{~g}$ for triplets $(n=1,311), 1253 \mathrm{~g}$ for quadruplets $(\mathrm{n}=132), 900 \mathrm{~g}$ for quintuplets $(n=12)$ and $630 \mathrm{~g}$ for sextuplets $(n=5)$, respectively. In each category of plural births, it was commonly observed that the weight was higher in males than in females, and the higher the birth order, the higher the weight. Low birth weight, less than or equal to $2500 \mathrm{~g}$, was seen in $54.7 \%(26,914 / 49,223)$ of twins, $92.0 \%$ $(1,206 / 1,311)$ triplets, $100 \%$ quadruplets(132/132), quintuplets $(12 / 12)$ and sextuplets $(5 / 5)$. Mean gestational age(week) was 36.7 for twins $(n=49,240), 33.7$ for triplets $(n=1,311), 30.3$ forquadruplets $(n=132), 26.7$ for quintuplets $(n=12)$ and 24.0 for $\operatorname{sextuplets}(n=5)$. 


\section{53}

INTRAUTERINE GROWTH OF TWINS IN JAPAN --- AN ANALYSIS FROM BIRTH CERTIFICATES 1988-1990. Noriko KAT0 (The Institute of Public Health, Tokyo) and Akio ASAKA (Yamanashi Medical. University, Yamanashi)

Intrauterine growth curves of twins, that is, birthweights according to gestational ages, are calculated from corresponding data of 49,240 birth certificates from 1988 to 1990 .

Through the gestational ages, mean birthweights of male were ca. $100 \mathrm{~g}$ larger than female. Compared to singleton births in Japan (Nishida 1984), mean birthweight of twins was ca, $150 \mathrm{~g}$ smaller until gestational age of 34 weeks, then the difference got larger, to ca. $500 \mathrm{~g}$ at the 4.2 weeks of gestation. As for birth order, mean birthweight of the $1 \mathrm{st}$ twins was ca. $100 \mathrm{~g}$ larger than that of the 2nd at gestational age of 42 weeks, and standard deviation was larger in the 2nd twins. Birthweight of twins from multiparous was ca. $200 \mathrm{~g}$ larger than those from primiparous at 4.2 weeks.

The pairs of twins were identified by date and place of birth, ages of parents, and gestational age. 23957 pairs were identified. Unlike-sexed twins showed the mean birthweight $50 \mathrm{~g}$ larger than those of like-sexed.

\section{54}

A BOY WITH "B-ALANINURIA", EPILEPSY AND DEVELOPEMENTAL DELAY AND GENETIC COUNSELING FOR HIS PARENTS, Hiroshi NAKAI, Mitoshi ARAYA, Kouichiro IKE, Toshio OHARA and Masako HIROTA. (Dept. Pediatr., Iwate Prefectural Center Hospital, Morioka)

A four-year-old boy wit "B-alaninuria", epileptic seizures and developemental retardation was reported. He was a only product of a non-consanguinous couple. The boy did not show hyper-B-alaninemia , and liquor concentration of -alanin was in normal ranges. GABA level in liquor, blood, and urine of the patient were also higher than control, respectively. His parents' B-alanin levels were not abnormal. There are no reports of a established concept of such disorder which showed "B-alaninuria", epilepsy and developemental delay. Hyper excretion of B-alanin in urine may due to a dysfunction of the $\beta$-amino acid transport system in renal tubles. It is not known whether B-alaninuria causes epilepsy or developemental delay.

Genetic counseling of this condition is difficult before establishment of the abnormal disorder. Accumulation of same cases is essential for this work. 


\section{55}

PSYCHOLOGICAL ASPECTS OF THE MOTHERS REFUSED THE AMNIOCENTESIS FOR PRENATAL DIAGNOSIS. Kunio MATAYOSHI, Nobumasa IKEHATA, Toshihumi TANAKA. (Dept. of Obstet. Gynecol., Tokyo Medical College Kasumigaura Hospital, Ibaraki)

Amniocentesis for prenatal diagnosis have spreaded among the pregnant women such as advanced age pregnancy or chromosomal abnormal baby's mother. But recently the pregnant women who refuse the amniocentesis for prenatal diagnosis have increased in spite of elederly primiparity or the delivery of chromosomal abnormal baby in the previous pregnancy. This tendency is remarkable since 1989. In our Genetic Counseling Section, $20.2 \%$ of these pregnant women refused the prenatal diagnosis during the last three years, nevertheless these women have enough informations and besides understand the necessity and the importance for prenatal diagnosis through counseling. For these women, the most greatest reason of refusing the diagnosis and continuing the pregnancy without examination is strong desire of catching a baby. It is interesting that this decision is made by the pregnant woman herself in many cases.

C 56

GENETIC COUNSELLING AND INTERNATIONAL BIOETHICAL OPINION SURVEY. Shigeaki NAKAZAKI (Kitagata National Sanatorium, Fukui, JAPAN), Norio FUJIKI, Mikio HIRAYAMA (Fukui Medical School, Fukui, JAPAN), Kazuo MANO (Nagoya First Red Cross Hospital, Aichi, JAPAN), Ishiwar C. VERMA (A11 Indía Institute of Medical Sciences, New Delhi, INDIA) and Pinit RATANAKUL (Mahidol University, Bangkok, THAILAND)

We have performed 2559 genetic counselling and opinion survey on heredity and handicapped to general public and medical students for over 30 years. We analyze these cases on one decade period. In recent years, the interests for genetic medicine has increased, but the limited knowledges might lead to misunderstandings and prejudices, even in medical students. We have started practical education of bioethics. After visiting institutions for the handicapped, medical students agree on the dignity of human being.

This time, we try to make international opinion survey on ethics in medical genetics, and compare the data in India and Thailand, with results in Japan. For prenatal diagnosis, Japanese attitudes are similar to those of other Asian countries, but explicit differences are found regarding determinants of abortion attitudes and sexual selection, probably due to the religious and social reasons. This variety must be respected, and our scientific knowledges should be used only to promote the human dignity and preserve the integrity and the future of man. 
D 1

TARGETED DISRUPTION OF THE XPAC GENE IN MICE. Shunsuke YUBA ${ }^{1}$, Yoko KATO $^{2}$, Yukio TSUNODA ${ }^{2}$, Tomoyuki TOKUNAGA ${ }^{3}$, Tsukasa MATSUNAGA ${ }^{4}$, Osamu NIKAIDO ${ }^{4}$, Kunimitsu IWAI ${ }^{1}$ and Kiyoji TANAKA ${ }^{1}{ }^{1}$ Inst. Mol. Cell Biol. Osaka Univ., Osaka; ${ }^{2}$ Fac. Agri. Kinki Univ., Nara; ${ }^{3}$ Natl. Inst. Animal Industry, Ibaraki; and ${ }^{4} \mathrm{Fac}$.

Pharmceutical Sci. Kanazawa Univ., Kanazawa.)

Xeroderma pigmentosum(XP) is an autosomal recessive disease, characterized by sunlightinduced skin cancers and progressive neurodegeneration in some cases. Recently we cloned a mouse DNA repair gene that complements the defect of group A XP and named it the XPAC (XP group A Complementing) gene. XP group A model mice would be of great value for determining the in vivo roles of the XPAC gene and testing therapeutic regimens. Toward the establishment of XP model mice, we produced heterozygous mouse embryonic stem(ES) cell lines in which single allele of the XPAC gene was disrupted by homologous recombination. These cell lines have been used to generate chimeric mice and the XPAC mutation was transmitted to progeny by one male chimera. Interbreeding of heterozygous siblings yielded mice homozygous for the XPAC mutation. The phenotypic analysis revealed that the fibroblasts derived from the homozygous mouse was defective in DNA repair of the damages caused by UV light and as hypersensitive to killing by UV light as human XP fibroblast lines.

D 2

THE MISSENSE MUTATION OF G235R IS COMMON IN ARGININEMIA.

Takako UCHINO and Ichiro MATSUDA (Dept. Pediatr., Kumamoto Univ., Kumamoto)

\footnotetext{
Argininemia results from the deficiency of enzymatically activity of arginase, the last enzyme of nrea cycle. We analyzed arginase genes of four Japanese patients with argininemia and found the missense matation of $G 235 R^{-}$due to a substitution of $G$ to $C$ at 703 position (exon 7) in unrelated two patients. We tried to screen the G235R in seven non-Japanese patients with argininema by PCR using a mismatched primer. We detected the mutation in five nonJapanese patients from three families. Including two Japanese patients previously reported, seven patients from 11 has the missense mutation of G235R. This mutation seems to be importent in arginase gene from a patient with argininemia.
} 
D 3

TWO NOVEL FRAMESHIFT MUTATIONS ASSOCIATED WITH THE PRESENCE OF DIRECT REPEATS OF THE LDL RECEPTOR GENE IN

FAMILIAL HYPERCHOLESTEROLEMIA. Kimiko Yamakawa-Kobayashi ${ }^{1}$, Tsutomu Kobayashi ${ }^{1}$, Keijiro Saku ${ }^{2}$, and Hideo Hamaguchi ${ }^{1}\left({ }^{1}\right.$ Dept. Med. Genet., Inst. Basic Med. Sci., Univ. Tsukuba, Tsukuba; ${ }^{2}$ Dept. Inter. Med., Fukuoka Univ., Fukuoka)

Characterization of the mutations in the LDL receptor gene is useful for the elucidation of the generative mechanisms that underlie naturally occurring gene mutations, because mutant LDL receptor genes are retained in the general populations with a high frequency. In this study, two novel frameshift mutations were detected in the mutant LDL receptor genes responsible for familial hypercholesterolemia. One was five base-pairs (bp) insertion at codon 395 in exon 9, and the other was one nucleotide deletion at codon 531 in exon 11. Both mutations alter the reading frame and consequently produce premature stop codon in the epidermal growth factor (EGF) precursor homology region of the mature $\mathrm{LDL}$ receptor. With regard to the mechanism responsible for the generation of these frameshift mutations, a strand slipped mispairing mediated by short direct repeats is considered to be the most likely mechanism. The findings seem to support the hypothesis that a short direct repeat DNA sequence can have a profound influence on the stability of a given gene and promote human gene mutations.

D 4

SUPPRESSION OF SOMATIC MUTATION BY GERMLINE DEFECT. Masayuki HAKODA, Sakura HAYASIMOTO, Naoyuki KAMATANI, Sadao KASHIWAZAKI (Inst. Rheum., Tokyo Women's Medical College, Tokyo) and Tsukasa KOJIMA (Clin. Chem. Toranomon Hospital, Tokyo)

We have established a method for the detection of somatic mutation occurring in vivo in humans. In this system, mutant $T$ cells deficient in adenine phosphoribosyl transferase (APRT) activity are cloned using interleukin-2 from the peripheral blood of heterozygous individuals for APRT deficiency. It has been revealed that mutant $T$ cells exists at the frequency of as high as $1.3 \times 10^{-4}$. Southern blot analysis showed that approximately $80 \%$ of mutant $\mathrm{T}$ cells lost normal alleles, which is expressed as loss of heterozygosity (LOH). Since the intensity of retained fragment increased in many cases, somatic recombination was thought to be the relevant mechanisms. Recently, we have identified a heterozygote with low $(1 / 5 \sim 1 / 10)$ mutant $T$ cell frequency. However, the frequency of mutant T cells deficient in X-linked HPRT was in the usual range. In the APRT-mutant clones obtained from this individual, loss of normal allele was not observed. The lack of such mutational events $(\mathrm{LOH})$ is most probably the cause for the low mutant frequency. Major gene alteration (probably deletion) observed in the genetically mutant APRT allele of this individual, which has not been detected in the mutant alleles of other families of APRT deficiency was supposed to be the mechanisms for the suppression of $\mathrm{LOH}$. Although APRT locus has not any relevance to oncogenesis, loss of normal alleles is an important mechanisms for the inactivation of suppressor oncogenes. Thus, the similar kind of genetic defect leading to the suppression of $\mathrm{LOH}$ may relate to the difference of risk for the development of malignant tumors among individuals. 
D 5

DISTRIBUTION OF CGG REPEAT LENGTHS AT THE FRAGILE SITE IN JAPANESE AND CHANGES OF THE LENGTHS THROUGH GENERATIONS. Tadao ARINAMI, Midori ASANO, Kimiko KOBAYASHI, Hideo HAMAGUCHI (Dept. Med. Genet., Univ. Tsukuba, Tsukuba)

One of the purposes of the present study is to reveal the distribution of CGG repeat lengths in the FMR-1 gene in the Japanese population. Assessing length variations of unrelated 386 males showed that the most frequent allele was a CGG repeat number of 28 followed by 29 , and 35 which allele frequencies were $41.5 \%, 31.1 \%$ and $7.5 \%$, respectively. Although the overall distribution in our population appears to be similar as that in $492 \mathrm{X}$ chromosomes from four different races (Caucasian, Black, Hispanic, and Asian) presented by Fu et al. (1991), the most frequent allele in our population was a CGG repeat number of 28 in contrast to 29 in that studied by Fu et al. and the distribution in our population had smaller variability than that reported by Fu et al. did. The distribution is significantly different between our population and that studied by Fu et al. ( $p=0.0266$, Kolmogorov-Smirnov two tailed test), suggesting that there are racial/ethic differences in distribution of CGG repeat lengths in FMR-1. Another purpose of the present study was to estimate mutation rates of CGG repeat lengths through generations in the normal populations. Changes of CGG repeat lengths were evaluated in 305 gametes consisting of 71 sperms and 234 ova by comparing CGG repeat lengths in parents and their children. One change from a repeat number of 28 in a father to that of 28 in a daughter was found, suggesting high mutation rates of CGG repeat lengths in normal populations.

D 6

ONE BASE SUBSTITUTION IN BAND 4.2 cDNA ASSOCIATED WITH AUTOSOMAL RECESSIVELY INHERITATED ERYTHROCYTE BAND 4.2 DEFICIENCY. Sadahike IWAMOTO, Eiji KAJII, Toshinori OMI, Sigenori IKEMOTO (Dept. of Legal Med. and Human Genet., Jichi Medical School, Tochigi), Toyomi KAMESAKI and Youichi AKIEUת (Dept. of Int.Med., Tottori Prefectural Central Hospital, Tottori)

A 27 year-old Japanese female who represented Coombs negative hemolytic anemia was studied. SDS-PAGE of the erythrocyte membrane proteins revealed a deficiency of band 4.2. A sister of the propositus was also shown to be deficient of band 4.2. Binding studies showed that the propositus membranes bound band 4.2 protein isolated from a normal subject. We analyzed the band $4.2 \mathrm{cDNA}$ of the propositus by reverse transcription-polymerase chain reaction and detected one base substitution that changes a codon for alanine to one for threonine at residue 142. Band 4.2 exon $\mathbb{I I}$ of genomic DNA which contains the mutation position were amplified and sequenced directly in the family members, and it was revealed that only the homozygotes of the mutation allele manifested band 4.2 deficiency and the heterozygotes showed normal erythrocyte membrane protein construction. Recently, same mutation was reported as Protein $4.2^{\text {NIPPON }}$ in another four cases by Bouhassira et al. (Blood 79:1846-1854, 1992). This study support the hypothesis that this mutation is the pathogenesis of band 4.2 deficiency not a polymorphism. 


\section{7}

CHROMOSOME ABNORMALITY 17p- AND MUTANT p53 mRNA DETECTED IN BONE MARROW CELLS OF AN ACUTE MYELOBLASTIC LEUKFMIA FAB M2 PATIENT IN RELAPSE. Tamiko SHINOHARA (Dept. Human Cytogenet., Japan Red Cross Med. Centr., Tokyo), Hiroki MATSUOKA, Kouichi INOKUCHI, Kazuo DAN and Takeo NOMURA (Dept. Internal Med., Nihon Med.Collage, Tokyo).

The cytogenetic analysis and p53 gene sequence analysis of bone marrow cells from a 46-year-old male with an acute myeloblastic leukemia( AML) FAB M2 are reported. The patient was admitted to the Nihon Medical Collage Hospital because of malaise and recurrent high fever on March 22 1991. At admission, bone marrow aspirates showed hypercellular, contained $58 \%$ myeloblasts. He was diagnosed as AML FAB M2. Chromosome study: chromosome analysis of bone marrow cells showed $46, X Y$ at admission, and $46, \mathrm{XY}, 17 \mathrm{p}-(58 \%) / 45, \mathrm{XY},-14,-17,+\operatorname{der}(14) \mathrm{t}(14 ; 17)(\mathrm{p} 11 ; \mathrm{q} 11)(42 \%)$ in relapse. Sequence analysis: mutation detected was $\mathrm{C} \rightarrow \mathrm{T}$ substitution at codon 248 of total RNA extracted from relapse sample. No mutation was detected in RNA at diagnostic sample. If both wild-type and mutation p53 mRNA are expressed, we can obtain sequence ladders of both wildtype and mutant p53 mRNA with same intensity. But wild-type ladder(C ladder) was not seen in the relapse sample, which means that leukemic cells have one p53 gene loss at chromosome $17 \mathrm{p}$ - with a mutation in the remaining p53 gene. Loss of the normal p53 function may be important in the progression of the present leukemia.

\section{8}

THE APPPOACH TO THE PREIMPLANTATION DIAGNOSIS BY PCR Kenji IDA, Yoichi NODA, Takahide MORI (Dept.Gynecol .Obstet., Kyoto Univ., Kyoto) Mayumi SATO, Takashi YAGI, Hiraku TAKEBE(Dept.Experimental Radiology, Facul ty of Med., Kyoto Univ., Kyoto)

In 1989 Handyside et al. has shown that it was possible to take out one blastomere from $6 \sim 10$ cel ls embryo and by amplyfying $Y$ specific sequence select female embryo from male embryo avoiding the birth of recessive X-linked genetic disease patients. In the approach to this technique of ampl ifying DNA from limi ted quantity of DNA, we using several primers as c-N-ras as single copy gene on autosomal chromosome, and mouse Sry sequence, human $X \& Y$ alphoid repeat as the sex determinant examined to improve detection limit on somatic cells and mouse blastocysts. We detected c-N-ras gene from single human culture cell and detected human $\mathrm{Y}$ alphoid repeat on 2pg of DNA extract from human lymphocytes. Also, it was possible to detect Sry sequence on $1 / 2$ mouse blastocysts. 
D 9

Detection of Y-specific DNA and mitochondrial DNA sequences by PCR amplification using DNA templates extracted from fixed cells. Yasuhiro SOTOZONO1.2) Yoshihiko NOJO11. Atsuko OGAWA11. Kazue NAKAMURA11. Osamu MIKAM 11. Yoshinobu TAKEMOTO3) Hiroshi WADA3) Takahiro OKAMOTO3) Akihisa KANAMARU3). Takuma KONDO41. Hiroko EUJITA5) Tomoko HAYASH (6) Ken-ichi KAKUDOZI, Tomoko Hashimoto1) and Jun-ichi FURUYAMA1) 1) Dept.Genet.,Hyogo Coll. Med., Nishinomiya, 2) Dept. Pediatr., Kyoto Pref.Univ.Med.,Kyoto, 3) IInd Dept.Int.Med.,Hyogo Coll.Med., Nishino-miya, 4)Konohana Public Health Center,Osaka , 5) Dept.Gerontol.,Hum.Devel. Welfare,Facult.Sci.Liv.,Osaka City Univ.,Osaka, 6) Dept. Bacteriol., Hyogo Coll. Med., Nishinomiya, 7)IInd Dept.Pathol.,Wakayama Med.Coll. Wakayama)

Blood smears and formalin-fixed paraffin-embedded tissue sections are only materials available for retrospective DNA analysis. We attempted to do PCR analysis using DNAs extracted from these materials. In the case of sexmismatched bone marrow transplantation, we amplified $Y$-chromosome-specific DNA from Giemsa-stained blood cells obtained 11 years ago. For Leber's hereditary optic neuropathy, we detected a point mutation in mitochondrial DNA from a patient's necropsy speciman obtained 25 years ago. In this case, heteroplasic state of the mutation was also observed. Thus, our method is quite useful for retrospective DNA diagnosis.

\section{10}

ANALYSIS OF THE DOPAMINE D2 GENE IN SCHIZOPHRENIC PATIENTS. Masanari ITOKAWA, Michio TORU (Dept. Psychiat., Tokyo Medical Dental University) and Tadao ARINAMI, Hideo HAMAGUCHI (Dept.Mecical Genetics, Tsukuba University)

When taking antipsychotics, most of the people are suppressed mentally and suffer from heavy side effects. In contrast, schizophrenic patients do not show such a strong mental suppression nor heavy side effects even when they take a large amount of antipsychotics. One of possible reasons for the resistance to antipsychotics observed in schizophrenic patients would be the alteration in the molecular structure of dopamine D2 receptor, which is the binding site of majority of the antipsychotics, in the schizophrenics. On the basis of the assumption that the dopamine D2 receptor gene is one of the candidate genes susceptible to schizophrenics, we analyzed the whole coding region of the gene in 50 Japanese schizophrenic patients with PCR-SSCP and direct sequencing methods. No mutation has been found until now, except for a polymorphism at $3420 \mathrm{C} / \mathrm{T}$ in exon 7 , which was already reported by Sarkar et al. (1991), in about a half of the patients. These results suggest that the structural abnormality of dopamine D2 receptor is not responsible for the suseptibility to schizophrenics in most of the patient. 


\section{11}

A HIGH-RESOLUTION CYTOGENETIC MAP OF HUMAN CHROMOSOME 5 WITH 206 NEW COSMIDS BY DIRECT R-BANDING FLUORESCENCE IN SITU HYBRIDIZATION. Eiichi TAKAHASHI, Akitsu HITOMI (Div. Genet., Natl. Inst. Radiol. Sci., Chiba) and Yusuke NAKAMURA (Div. Biochem., Cancer Inst., Tokyo)

We constructed a new cosmid library of human chromosome 5 (cCI5) and localized 206 clones by direct R-banding FISH. This FISH system allows more rapid and efficient construction of cytogenetic maps. The signals of 206 clones were evenly distributed throughout chromosome 5, but sublocalized preferentially to R-positive bands. This bias may be due to the procedures for the selection of colonies, but not due to the procedures of R-banding. This high-resolution and high-density cytogenetic map (average map of $0.94 \mathrm{Mb}$ ) makes it easier to construct a linkage map, which is essential for positional cloning of responsible genes. The genes responsible for XRCC4, SMA, LGMD1 and TCOF1 have been assigned to chromosome 5. In addition, an impressive number of genes encoding growth factors, growth factor receptors and hormon/neurotransmitter receptors have been mapped to the long arm of this chromosome. Chromosome 5 also contains chromosomal fragile sites and cancer-breakpoints. These mapping data provide many useful landmarks for the construction of contig maps with cosmids and YACs, as required in Human Genome Project.

\section{12}

SIMULTANEOUS DETECTION OF EIGHT CHROMOSOME BANDS ALONG X CHROMOSOME BY TWO-COLOR FLUORESCENCE IN SITU HYBRIDIZATION WITH BAND-SPECIFIC YAC CLONES. Masafumi TANIWAKI (Third Dept. Intern. Med., Kyoto Pref. Univ. Med., Kyoto) and Thomas CREMER (Inst. Humangenetik und Anthropologie, Univ. Heidelberg)

$X$-specific YAC clones were hybridized to chromosomes to generate new types of colored staining pattern, called chromosomal bar codes. Alu-PCR amplification products from eight YAC clones mapping to bands on the long arm and the short arm of the human $X$ chromosome were used to detect the respective target band. Alternative green and red signals could be observed along the $\mathrm{X}$ chromosome by two-color chromosomal in situ suppression (CISS) hybridization. The bar code approach has the potential to identify inter- and intrachromosomal rearrangements, thereby refining cytogenetic data and providing the new diagnostic tool for clinical cytogenetics. 
D 13

\begin{abstract}
ASSIGNMENT OF THE HUMAN ATL-DIRIVED FACTOR GENE (ADF) TO CHROMOSOME 9 AT RESION q32 BY FLUORESCENT IN SITU HYBRIDIZATION. Takeshi ARIYAMA ${ }^{1,2}$, Johji INAZAWA ${ }^{1}$, Atsushi HORIUCHI ${ }^{2}$, Junji YODOI $^{3}$ and Tatsuo ABE${ }^{1}$ ('Dept. Hygiene, Kyoto Pref. Univ. Med., Kyoto, ${ }^{23 r d}$. Dept. Med. Kinki Univ. Med., Osaka, ${ }^{3}$ Inst. Virus Res. Kyoto Univ., Kyoto)
\end{abstract}

ATL-derived factor (ADF) is a humoral factor, which is continuously produced by many HTLV-I transformed T cells from adult T cell leukemia (ATL) patient, and shows IL $-2 R / p 55(T a c)$ inducing activity. ADF is almost identical to human thioredoxin which shows dithiol-disulffied oxidoreductase activity.

In order to ideitify the chromosomal localization of ADF gene, we carried out fluorescent in situ hybridization (FISH) with ADF cosmid clone as probe. Fluorescent twinspot signal specific for this gene could be detected only on $9 \mathrm{q} 32$, although the human thioredoxin gene was previously mapped to 3p12-p11 (Lafage-Pochitaloff-Huvale et al. 1989). Therefore, we reassigned the human $\mathrm{ADF} /$ thioredoxin gene to chromosome 9 at region $\mathrm{q} 32$.

\title{
D 14
}

REGIONAL ASSIGNMENT OF THE HUMAN IMMUNOGLOBULIN PROCESSED PSEUDOGENE C 3 (IGHEP2) TO 9 p 24 BY FLUORESCENCE IN SITU HYBRIDIZATION. Hideyuki TANABE ${ }^{1}$, Takafumi ISHIDA ${ }^{2}$, Shintaroh UEDA $^{2}$, Hiroshi MIZUSAWA ${ }^{1}$ and Toshio SOFUNI ${ }^{1}$ (1 Div. Genet.\&Mutagenesis, Natl. Inst. Hygienic Sci., Tokyo 2 Dept. Anthrop., Fac. Sci., Univ. Tokyo, Tokyo)

The human immunoglobulin pseudogene $\mathrm{C} \varepsilon 3$ is categolized into the processed type pseudogene that lacks introns and has LTR-like elements with its both sides. It is known that the active immunoglobulin multigene family locates on the $14 \mathrm{q} 32.33$, whereas this pseudogene $C_{\varepsilon} 3$ has been assigned onto the chromosome 9 by the somatic cell hybrids analysis. Regional localization on the chromosome 9 of this gene was not identified as yet, thus we performed regional mapping using fluorescence in situ hybridization combinded with conventional QFQ, RBG or GTG banding. Fluorescent twin spot signals were detected on the terminus region of the short arm of the chromosome 9 band at $\mathrm{p} 24$ with metaphases of 300-800 bands stages.

Previous data from Southern analysis suggested that the processed $C_{\varepsilon}$ pseudogene was generated before the divergence between Old World monkeys and hominoids. Comparative mapping of this pseudogene to other primates would contribute to understanding not only for the origin of this gene but for the karyotype evolution of the catarrhine primates including Old World monkeys, apes and human. 


\section{15}

DNA POLYMORPHISM OF THE APOLIPOPROTEIN B GENE INVOLVED IN THE DETERMINATION OF SERUM CHOLESTEROL AND TRIGLYCERIDE LEVEL. Tetsuro MIKI, Toshio OGIHARA (Dept. Geriatric Med., Osaka Univ. Med. School, Osaka) Emiko MIYAZAKI, Yoshiko TABATA, Yuichi KUMAHARA (Sakuragaoka Hospite1, Nishinomiya)

We have analyzed the correlation between the ApoB DNA polymorphism and the serum concentration of $A p o B$ and lipid. Two types of DNA polymorphism, the $A$ poB signal peptide insertion(I)/deletion(D) polymorphism and the ApoB $3^{\prime}$ VNTR polymorphism, were studied by PCR. The triglyceride concentrations $(111.2+76.5 \mathrm{mg} / \mathrm{dl})$ of 26 individuals with homozygout for signal peptide I/I polymorphism were significantly higher than those $(84.9+39.3)$ of 69 individuals with heterozygout for $I / D(p<0.05)$. This result suggests that deletion of three amino acids in the signal peptide region may lead to the altered processing of $A$ poB and, as a result, to lower serum triglyceride levels. Based on the number of the repeat, the population is categorized into three groups, group A ( $<34$ repeats), group B ( $=35$ repeats), and group C $(>36$ repeats). Levels of total cholesterol in group $B(206.7+29.9 \mathrm{mg} / \mathrm{d} 1$, $\mathrm{n}=34$ ) was significantly higher than those in group $\mathrm{C}(189.9+26.4$, $\mathrm{n}=30)(\mathrm{P}<0.05)$. Our results support a notion that the ApoB $3^{\prime}$ VNTR region contribute to determine serum cholesterol levels.

\section{16}

FAMILIAL AGGREGATIONS OF HIGH PLASMA LIPOPROTEIN(a) LEVELS AND THEIR ASSOCIATIONS WITH SPECIFIC APOLIPOPROTEIN(a) ISOFORMS . Hisako YANAGI, Shuichi KIKUCHI, Akiko NAKAGAWA, Shigeru TSUCHIYA* and Hideo HAMAGUCHI (Dept.

Med. Genet., Inst. Basic Med. Sci., *Inst. Comm. Med., Univ. Tsukuba, Tsukuba 305, Japan)

The high level of plasma lipoprotein(a) $[\mathrm{Lp}(\mathrm{a})]$ is an independent risk factor for coronary heart disease. Individual differences in the molecular size of the apolipoprotein(a) [apo(a)], the important constituent of $L p(a)$, are inversely correlated with plasma $L p(a)$ levels. To reveal the presence of familial aggregations of high $L p(a)$ levels and their associations with a specific apo(a) isoform in each family, we have studied 16 families with high $\mathrm{Lp}$ (a) levels. The probands were 19 children belonging to 17 families who were screened out from 178 school-age children, and their $\operatorname{Lp}(\mathrm{a})$ levels were above 30 $\mathrm{mg} / \mathrm{dl}$ (90 percentile level, the high Lp(a) level). Among 25 different apo(a) isoforms which have been detected by gradient SDS/PAGE followed by immuno-blotting and designated A1 to A25 from the lowest to highest molecular weight in our laboratory, one of the isoforms, A2 to A12, was detected in all of the probands and 15 family members with high $\mathrm{Lp}$ (a) levels. In contrast, only three of the 17 family members with $\mathrm{Lp}(\mathrm{a})$ levels below $30 \mathrm{mg} / \mathrm{dl}$ had isoforms smaller than $\mathrm{A} 12$. The differences are significant. About half of the first degree relatives of the probands had high $L p(a)$ levels. Furthermore, high $\mathrm{Lp}$ (a) levels were co-segregated with a specific apo(a) isoform smaller than A12 in 15 out of the 16 families analyzed. These data suggest the presence of familial aggregations of high $L p(a)$ levels which is mainly caused by dominant alleles at the apo(a) locus. 
D 17

GENETIC POLYMORPHISM OF APOLIPOPROTEIN(a) ISOFORM AND ITS RELATION TO ISCHEMIC HEART DISEASE. Shuichi KIKUCHI, Hideo HAMAGUCHI (Dept. Med. Genet., Univ. Tsukuba) and Hiroshi AMEMIYA (Dept. Cardiol., Tshuchiura Kyodo Hospital)

High plasma lipoprotein(a) [Lp(a)] levels are known to be an independent risk factor for ischemic heart disease (IHD). Apolipoprotein(a) [apo(a)] is a major component of Lp(a) and exhibits extremely high degree of genetic size polymorphism. We have developed a sensitive high-resolution method for the analysis of apo(a) and detected 25 different isoforms which were designated as A1 to A25 from the lowest to highest molecular weight. There is an inverse correlation between plasma $\mathrm{Lp}(\mathrm{a})$ levels and the size of apo(a) isoforms. In this study, we evaluated the role of plasma Lp(a) levels and the genetic polymorphism of apo(a) isoforms in IHD. Subjects consisted of 144 patients with IHD whose onset were under 60 y.o. and 57 controls with normal coronary artery. The subjects with plasma $\mathrm{Lp}(\mathrm{a})$ levels above $30 \mathrm{mg} / \mathrm{dl}$ were significantly increased in the IHD patients $(30.6 \%)$ compared with controls $(12.3 \%)$ ( $p<0.01)$. The subjects with small size apo(a) isoforms (smaller than A13) were also significantly increased in the IHD patients $(39.0 \%)$ compared with controls $(17.8 \%) \quad(\mathrm{p}<0.01)$. It was suggested that small size apo(a) isoforms are a genetic risk factor for IHD.

\section{18}

CORRELATION BETWEEN PLASMA LP(a) LEVELS AND THE POLYMORPHISM OF APO(a) IN THE CHINESE HAN POPULATION. Liming LI, Shuichi KIKUCHI, Tadao ARINAMI, Hideo HAMAGUCHI (Dept. Med. Genet. Univ. Tsukuba)

High plasma Lipoprotein(a) [Lp(a)] levels are an independent risk factor for coronary heart disease. Apolipoprotein(a) [apo(a)] is homologous of plasminogen and an important constituent of $L p(a)$. Several studies have shown that the molecular sizes of apo(a) isoform are determined by polymorphic alleles at the apo(a) locus and inversely correlated with plasma $\mathrm{Lp}(\mathrm{a})$ levels. This study was done to elucidate the distribution of plasma $L p(a)$ levels, the genetic polymorphism of apo(a), and the relationship between them in the Chinese Han population. Twenty-three different isoforms of apo(a) have been detected and the number of alleles of apo(a), including a null allele, were 24 in 104 unrelated healthy Chinese Han students studying in University of Tsukuba. Plasma Lp(a) concentration varied markedly among 104 subjects (ranged from 0.3 to $75.8 \mathrm{mg} / \mathrm{dl}$ ) and represented a skewed distribution towards lower levels. A strong inverse correlation between the molecular sizes of apo(a) isoforms and plasma levels of $L p(a)$ were observed in 104 students $(r=-0.704, p=0.0001)$. The data indicate that apo(a) is highly polymorphic and it's alleles are associated with plasma $\mathrm{Lp}$ (a) levels in the Chinese Han population as in the Japanese population. 
D 19

HIGH SERUM LIPOPROTEIN(a) LEVELS ARE AN INDEPENDENT RISK FACTOR FOR CEREBRAL INFARCTION. Shuzo SHINTANI (Dept. Neurol., Toride Kyodo General Hospital), Shuichi KIKUCHI, Hideo HAMAGUCHI (Dept. Med. Genet., Univ. Tsukuba) and Tatsuo SHIIGAI (Dept. Int. Med., Toride Kyodo General Hospital)

The role of high serum lipoprotein(a) $[\mathrm{Lp}(\mathrm{a})]$ levels in the development of the cortical artery occlusion (CAO) and perforating artery occlusion (PAO) types of cerebral infarction was evaluated. Subjects examined consisted of 54 patients with cerebral infarction (37 males and 17 females, $61.9 \pm 7.7$ y.o.) and 81 age-matched normal controls ( 66 males and 15 females, $61.1 \pm 8.6$ y.o.). The patients were classified into subtypes: 38 cases of PAO, 14 cases of CAO, and two cases of both types. LP(a) levels were measured with ELISA kit. The subjects with serum Lp(a) levels above $30 \mathrm{mg} / \mathrm{dl}$ were significantly increased in the total patients $(p<0.01)$, the PAO group $(p<0.02)$, and the CAO group $(p<0.02)$ compared with controls. Serum $\mathrm{Lp}(\mathrm{a})$ levels were not significantly correlated with HDL-cholesterol levels, and the ratio of hypertension, smoking, and atrial fibrillation in which statistical differences were observed between patients and controls. The mean values of fasting blood sugar and the ratio of diabetes mellitus which is the only known factors associated with the serum $\mathrm{Lp}(\mathrm{a})$ levels, were not significantly different. These findings indicate that high serum $L p(a)$ levels are an independent risk factor in the development of the CAO and PAO types of cerebral infarction.

\section{20}

IDENTIFICATION OF MICROSATELLITE REPEAT POLYMORPHISMS IN THE PLACENTAL ALKALINE PHOSPHATASE GENE. Zentaro YAMAGATA, Sumio IIJIMA, Akio ASAKA (Dept. of Health Sciences, Yamanashi Medical Univ., Yamanashi) and Moyra SMITH (Univ. of California Irvine, USA)

\footnotetext{
Examination of published sequence of placental alkaline phosphatase revealed the presence of (AC) n repeats in position 542-565. We utilized sequence information to design primers to amplify a DNA fragment of approximately 112 bases in a PCR reaction. Use of this primer set led to the identification of six allele polymorphisms. We utilized DNA from human hamster somatic cell hybrids to confirm that the polymorphisms are dependent on the presence of human chromosome 2. This primer set also led to the amplification of DNA present in the intestinal alkaline phosphatase gene, evidenced by amplification of DNA from the clone IAP8, which contains the intestinal alkaline phosphatase gene. The product derive from the IALP (Intestinal alkaline phosphatase) gene migrated differently to the polymorphic alleles, in denaturing acrylamid gels. This polymorphism will be valuable for linkage analysis.
} 


\section{21}

TRISOMY OF CHROMOSOME 7 ANALYZED BY FLUORESCENCE IN SITU HYBRIDIZATION IN HUMAN RENAL CELL CARCINOMA. Mitsuaki A. YOSHIDA and Tatsuro IKEUCHI (Dept. of Cytogenet., Med. Res. Inst., Tokyo Med. \& Dent. Univ., Tokyo)

Gain of chromosome 7 was frequently observed in cultured mitotic cells from human renal cell carcinoma(RCC). In order to evaluate the significant roles(s) of trisomy 7 in RCC development, the frequency of trisomy 7 in interphase cells was analyzed by fluorescenct in situ hybridization (FISH) using $\alpha$-satellite DNA probe (D7Z1/D7Z2), and the results were compared with those obtained by chromosome analyses in mitotic cells. A total of 12 specimens ( 6 RCCs and 6 normal kidney tissues) were analyzed for FISH in interphase cells of the short-term culture, and the karyotype analyses were performed on 8 cultured specimens ( 5 RCCs and 2 normal tissues). The frequency of trisomy 7 in RCCs varied from $0.8-86 \%$ in interphase cells and $0-100 \%$ in karyotype analyses. The frequencies in interphase cells were not necessarily consistent with those in mitotic cells. Of particular interest was the findings that the cells showing trisomy 7 existed in cultured normal tissues. We also applied FISH to 5 primary tissues ( 3 RCCs and 2 normal kidney tissues) from three patients, and 3 RCCS and one normal tissue were found to show trisomy 7 , indicating that a gain of chromosome 7 was not a product in vitro condition. The results in this study suggest that the combining analyses in interphase and mitotic cells may offer the advantage to the accurate detection of cells with numerical chromosome abnormalities.

\section{22}

New diagnostic method for Pallister-Killian syndrome: Detection of $i(12 p)$ in interphase nuclei of buccal mucosa by fluorescence in situ hybridization. Hirofumi Ohashi, Hiroyoshi Imura, Norio Hashimoto, Yoshimitsu Fukushima (Saitama Children's Medical Center, Saitama) and Satoshi Ishikiriyama (Chiaba Children's Hospital, Chiba)

Detection of the supernumerary isochromosome 12p [i(12p)] was performed on buccal smear preparations from two patients with Pallister-Killian syndrome, aged $19 / 12$ years (Patient 1) and 15 months (Patient 2), by interphase fluorescence in situ hybridization (FISH) using chromosome 12specific alpha satelitie probe(D12Z3, Oncor). i(12p)positive cells were identified by observing 3 signals over the nucleus, while diploid cells by 2 signals. The proportion of $i(12 p)$-positive cells thus identified were high in the epithelial cells of buccal mucosa at $68 \%$ and $53 \%$ from Patients 1 and 2 , respectively. Detection of $i(12 p)$ using direct buccal smear preparations by interphase FISH is a rapid, effective and non-invasive method for diagnosis of Pallister-Killian syndrome. 


\section{23}

STRUCTURAL ANALYSIS OF pSU dic(13) BY USING MOLECULAR TECHNIQUES, Ryozo KASAI (Asahigawa Jidoin Hosp. for Handicap. Child., Okayama), Kouji NARAHARA, Kazushiro TSUJI, Yuji YOKOYAMA, Tsunenori MATSUBARA and Yoshiki SEINO (Dept. Pediatr., Okayama Univ. Med. School, Okayama)

To characterize the structure of a psu dic(13) in a patient with typical clinical features of the partial $13 q$ trisomy syndrome but no retinoblastoma, we conducted cytogenetic, gene dosage and molecular studies, Cytogenetic study by using $\mathrm{G}-, \mathrm{C}-, \mathrm{Cd}-, \mathrm{N}-$ and $\mathrm{Q}$-banding indicated. that the psu dic(13) had a mirror image constitution, having occurred at the maternal meiosis. Gene dosages for ESD (on 13q14.114.2) and LCP1 (on 13q14.3) were normal. Southern blot analyses for D13S6 ( $\mathrm{pHU} 10$ ), D13S1 ( $\mathrm{p} 7 \mathrm{~F} 12$ ) and D13S4 ( $\mathrm{p} 1 \mathrm{E} 8$ ), which have been mapped to $13 \mathrm{q} 12.3, \mathrm{q} 13$ and $\mathrm{q} 31$, respectively, showed 2 copies of $\mathrm{D} 13 \mathrm{~s} 6$ and D13S1 and 3 copies of D13S4. While there were 10.1 and $7.4 \mathrm{~Kb}$ heterozygous alleles for D13S4 of both parents, that of the patient had only the $7.4 \mathrm{~Kb}$ allele. These findings suggest that the psu dic(13) had occurred at the maternal meiosis II, and its constitution was qter $\rightarrow$ $\mathrm{q} 21.1:: \mathrm{p} 13 \rightarrow$ cen $\rightarrow \mathrm{q} 14.3:: \mathrm{q} 11 \rightarrow \mathrm{p} 13:: \mathrm{q} 21.1 \rightarrow \mathrm{qter}$. The use of molecular study is of particular importance in examing complex structural abnormalities of chromosomes.

\section{24}

MOLECULAR DISSECTION OF THE PRADER-WILLI/ANGELMAN SYNDROME REGION BY YAC CONTIG AND FISH ANALYSIS.

Akira KUWANO (Dep. Pediatr., Yamaguchi Univ), Shinji SAITOH, Norio NIIKAWA (Dep. Hum. Genet., Nagasaki Univ.), Apiwatt MUTIRANGURA, Susan A. LEDBETTER, David H, LEDBETTER (Inst. Mol. Genet., Baylor Coll. Med., Houston, TX, USA)

Yeast artificial chromosome (YAC) clones were isolated for 10 DNA probes in the Prader-Willi/Angelman syndrome region (15q11-13). The order of YACs, determined by multi-color FISH on interphase nuclei in combination with YAC contig information is as follows: cen--IR39--ML34--IR4-3R--TD189-1-PW71 - LS6-1--TD3-21--GABRB3--IR10--CMW-1--tel.

FISH analysis with these YACs was performed on 8 cases of PWS and 3 cases of AS, including 6 patients with normal karyotypes. All eleven patients were deleted for YACs in the interval IR4-3R- $\rightarrow$ GABR3. FISH analysis on a previously reported case of familial As also confirmed a submicroscopic deletion including YACs corresponding to LS6-1, TD3-21 and GABR3, but not other markers. This finding supports the separation of the PWS and AS critical regions, with AS more distally located. The size of the AS critical region is $>650 \mathrm{~kb}$ since these three deleted YACs do not overlap each other. 
D 25

CLINICAL APPLICATION OF FLUORESCENCE IN SITU HYBRIDIZATION: DIAGNOSIS OF SEX CHROMOSOME ABNORMALITIES. Takako TAKANO, Yasuko YAMANOUCHI (Dept. Hygiene, Teikyo Univ., Tokyo), Mitsushiro KIDA, Shouko KAWASHIMA (Dept. Pediat., Teikyo Univ.), Katsuya AIZU, Shinya ENOMOTO (Dept. Pediat., Kumagaya Consumer's Co-operative Hospital, Saitama), Yutaka NAKAHORI and Yasuo NAKAGOME (Dept. Hum. Genet., Tokyo University)

Fluorescence in situ hybridization (FISH) is useful for diagnosis of minute chromosome abnormalities which could not have been detected by conventional chromosomal banding techniques. We have reported two cases of sex chromosome abnormalities detected by FISH.

Patient 1 is a 13 year old boy with short stature (-3.2SD). His karyotype was $46, Y, X p+$. Extra segment of $\mathrm{Xp}+$ was revealed as another Yq carried from his mother by FISH using the probe DYZ1. Patient 2 is a 1 year old boy with congenital heart disease (ASD+PDA, PH), left inguinal hernia, multiple minor anomalies and delayed development. Chromosome analysis showed 45,X/46,X,+mar constitution (3:37 cells). The marker chromosome was not fluorescent by $\mathrm{Q}$-banding. We detected fluorescent signals by FISH using the probe DYZ1 and DYZ3 on this marker chromosome. It was derived from $\mathrm{Y}$ chromosome from which the distal part of the long arm was deleted.

The technique of FISH is of clinical diagnostic value and will be widely used.

D 26

RAPID DETECTION OF MARKER CHROMOSOMES BY FLUORESCENT IN SITU HYBRIDIZATION. Keiichi MIYAGOE', Takeshi ARIYAMA ${ }^{2}$, Noriko MATSUDA $^{1}$, Mayumi FUJIMOTO ${ }^{1}$, Fumiko SUGIURA ${ }^{1}$, Johji INAZAWA ${ }^{2}$, Akihiko KINUGASA ${ }^{3}$, Tatsuo $\mathrm{ABE}^{2}$ ('Kyoto Microbial Inst., Kyoto, Dept. ${ }^{2} \mathrm{Hygiene}$ and ${ }^{3 \mathrm{Pe}-}$ diatrics, Kyoto Pref. Univ. Med., Kyoto)

We report the identification of marker chromosomes in two patients with clinical phenotypes associated with sex chromosome aberrations. One showed $45, X,-X / 46, X,-$ $\mathrm{X},+\mathrm{r}(\mathrm{X})$, and the other, $45, \mathrm{X},-\mathrm{X} / 46, \mathrm{X},-\mathrm{X},+$ mar. To identify the origin of these markers, we carried out fluorescent in situ hybridization (FISH) using $X$ and/or $Y$ chromosome specific probes of DXZ1, DYZ1 and DYZ3. X and Y specific signals on the centromeric region of $\mathrm{r}(\mathrm{X})$ and on the centromere of marker chromosomes could be detected, respectively. These results allowed us to determine the origin of each marker chromosome. 
D 27

Fluorescence in situ hybridization (FISH) on interphase nuclei-detection of chromosoaml abnormalities of hematologically malignant cells and of chimerism of blood cells after bone marrow transplantation. Atusko OGAWA11. Tomoko HASHIMOTO11. Osamu MIKAM(1). Yoshinobu TAKEMOTO2) Hiroshi WADA2) Takahiro OKAMOTO2), Akihisa KANAMARU2), Kiyoyasu NAGAI2), and Jun-ichi FURUYAMA1) . 1) Dept. Genet., and 2) IInd Dept. Int. Med., Hyogo Coll. Med., Nishinomiya

FISH technique is useful to obtain chromosomal information in interphase nuclei. Using biotinilated a-satellite sequence as probes, FITC-positive spots can be detected in more than $99 \%$ of interphase nuclei of blood cells including granulocytes. Using D8Z1 probe, trisomy 8 was found in CML and MDS blastic crisis. This technique is also useful to detect the surviving rate of the bone marrow transplaned cells in recipients from a sexmismatched donor. Based on these results, we conclude that this method is of clinical value.

\section{28}

APPLICATION OF FLUORESCENCE IN SITU HYBRIDIZATION TECHNIQUE TO IDENTIFYING MARKER CHROMOSOMES

Mizuho TAKATA, Shozo TAMURA, Noriko FUJITA, Yuko SHIRAHATA, Shiro NOZAFA, (Dep. Obst. \& Gynec., Keio Univ. Sho. Med.) Yukari YANAGI, (Keio Health Counseling Center) Shinsei MINOSHIMA, Nobuyoshi SHIMIZU (Dept. Mol. Biol., Keio Univ. Sch. Med.)

We applied FISH technique to identify the marker chromosomes and confirm exact breakpoint of the translocation in two clinical cases.

Case 1 : Chromosomal analysis of cells obtained by amniocentesis revealed a fetal karyotype of $47, X X,+m a r$. Since the client refused further examination, we examined the marker chromosome of fetal cells using human centromere specific probes, RI(680)(for chromosomes 13 and 21), XI(1020) (for chromosomes 14 and 22) and rDNA probe, pRSS15. FISH analysis was indicated that the marker chromosome has a short arm of chromosome 14 or 22. Later the client agreed for further examination. Her karyotype was $46, \mathrm{XX}, \mathrm{t}(8 ; 14)$. Based on these findings, it was confirmed that the fetal marker chromosome was der(14) (14pter $>14$ cen>8pter).

Case 2 : Fetal and maternal karyotypes were $46, X X, \operatorname{rcp}(9 ; 22)$. The results of FISH using XI probe and chromosome 22 specific probes, $\mathrm{C} 2$ and CEB1-B2 (cat eye marker chromosome-derived cosmid clone), indicated that the breakpoint of chromosome 22 is located between C 2 and CEB-1-B2 probes.

Our data suggest that FISH technique is useful to identify marker chromosomes and chromosomal breakpoints. 


\section{29}

ANALYSIS OF CHROMOSOMAL HOMOLOGIES AMONG HIGHER PRIMATES BY CHROMOSOME PAINTING. Yumiko SUUTOU and Momoki HIRAI (Dept. Anthropol., Fac. Sci., Univ. Tokyo, Tokyo)

Chromosomal in situ suppression hybridization using human chromosome -specific DNA libraries enables chromosome identification as well as determination of chromosome fragments in metaphase spread. This chromosome painting system will help study karyotype evolution in primates directly on the basis of DNA sequence homologies and may give insights into the role of chromosomal rearrangements in primate speciation. Combining this system with our improved G-banding method, we analyzed homologies among Homo sapiens (HSA, 2n=46), Papio hamadryas (PHA, 2n= 42) and Cercopithecus aethiops (CAE, $2 n=60$ ) chromosomes. Twelve DNA libraries, specific for human chromosomes 1-4,6-12 and $X$, were used as probes. Each human probe hybridized with the entire length of either one or two monkey chromosome(s). No complicated translocations were detected by use of these probes. These results indicate that the chromosomes are highly conserved in these species. We confirmed that the HSA2 probe hybridized with two Pan paniscus (PPA, 2n=48) chromosomes (PPA 12 and 13).

\section{30}

PARTIAL TRISOMY OF THE SHORT ARM OF CHROMOSOME 5. KOjI YASUTOMO, Takeshi SUZUE, Atsuko NISHIOKA, Hiroko KOUZAN, Takanori SEKIGUCHI, Katsuaki OHARA, Takashi OKAMOTO (Dept. Pediatrics, Takamatsu Red Cross Hospital, Kagawa) and Tsuyako IWAI, Shoichi ENDO (Dept. Pediatrics, Kagawa Children's Hospital, Kagawa)

We present unrelated two cases of partial trisomy of the short arm of chromosome 5, which has not been reported in Japan. The features are characterized by hypertelorism, low auricle, arachnodactyly, laryngostenosis, hypotonia and some cerebral malformation, one of which, the characteristic facial expression and arachnodactyly were supposed keys to diagnose this disorder.

High-resolution chromosome banding technique showed that the karyotype of first patient was $46 \mathrm{XX}$, inv dup (5) (p13.1 $\longrightarrow$ p15.3) de novo and that of second patient was $46 \mathrm{XX}$, dup $\operatorname{dir}(5)(\mathrm{p} 13.3 \longrightarrow \mathrm{p} 15.2)$ de novo. The similar symptoms in the two cases despite of the different karyotype were caused by duplication of $5 p$ including segment $5 p 13$ which would by a key site of this disorder. 


\section{31}

DE NOVO DISTAL 7q- IN A GIRL WITH CRANIOSYNOSTOSIS. TOmoko HASEGAWA, Takeyasu IGARASHI (Div. Clin. Genet. Shizuoka Children's Hospital, Shizuoka), Hiromi SATO, Noriko SATO (Div. Neurosurg. S.C.H., Shizuoka) and Koichi ENDO (Div. Clin. Path. S.C.H., Shizuoka).

The aetiology of craniosynostosis is heterogeneous, but genetic anomalies are thought to be the main cause. The recognized gene loci of craniosynostosis are on chromosomes $7 \mathrm{p}$ and $15 \mathrm{q}$, as mapped from case reports of $7 \mathrm{p}-$ and $15 \mathrm{q}-$. It has also been shown in various other chromosomal anomalies. We found a chromosomal deletion of $7 \mathrm{q}$ in a patient with craniosynostosis. The patient, a girl, came to our genetic clinic with a complaint of poor head size increase. Her OFC had been $31.0 \mathrm{~cm}$ at term birth $(-1.5 \mathrm{SD})$. At the age of 3 years, her OFC was $-3.7 \mathrm{SD}$. Skull X-P showed fusion of the coronal and sagittal sutures and massive digital marking on the cranium. Other remarkable findings were round face, full cheeks, blepharoptosis, low nasal bridge, flat nasal tip, large ears, short stature, mental retardation, peripheral hypertonia and abnormal dermatoglyphics. The patient's chromosomes apparently demonstrated del(7)(q35), however, an interstitial deletion of del(7) (q32.3q35) could not be ruled out. Although severe microcephaly is common in $7 \mathrm{q}$ - individuals, craniosynostosis has not yet been reported. Further information on $7 q-$ cases is required in order to ascertain whether a candidate gene for craniosynostosis is located on $7 \mathrm{q}$.

\section{32}

A case of $11 \mathrm{q}$ trisomy with multiple benign ring-shaped skin creases (the Michelin-tire baby syndrome). Yuko ENDO, Kesanori AONUMA and Atsushi KOMIYAMA (Dept. Pediatr., Shinshu Univ. Sch. Med., Matsumoto)

The patient is a one-year-old male born to 40-year-old father and 38year-old mother. His 11-year-old brother was asphyxic on his birth and diagnosed as having cerebral palsy. His sister died immediately after birth because of the congenital heart disease. His 2-year-old brother is healthy. After 39 weeks of gestation, he weighed $3200 \mathrm{gr}$. He visited our hospital because of the heart murmur and hypotonocity at 4-month-old. He was recognized as typical $11 \mathrm{q}$ trisomy syndrome showing short nose, long philtrum, retrognathia, short neck, inguinal hernias, congenital heart disease(ASDËsmall VSDC̈PS) and possible retăded myelinization of corpus callosum. On dermatoglyphics, he showed no Simian creases, 8 whorls and 2 ulnar loops and TRC was 166. His karyotype is $46, X Y,-13,+\operatorname{der}(13) t(11$; 13)(q22.2;p11)mat and that of his mother is $46, \mathrm{XX}, \mathrm{t}(11 ; 13)(\mathrm{q} 22.2 ; \mathrm{p} 11)$. In addition, he showed folding of excess skin on the trunk and limbs(the Michelin-tire baby syndrome) which is considered to be an autosomal dominant trait. 
D 33

A CASE OF A FEMALE INFANT WITH SIMULTANEOUS OCCURRENCE OF de nOVO TERMINAL DELETIONS ON CHROMOSOME 14q AND 20p. Shigeki UEHARA, Noriko MIYASHITA, Toshifumi TAKABAYASHI, Yukiko AKAI, Yoichi TAKEYAMA, Kunihiro OKAMURA, Akira YAJIMA (Dept. Obstet. Gynecol., Tohoku Univ. Sch. Med., Sendai)

This is a case report on an infant with de novo terminal deletions on the long arm of chromosome 14 and on the short arm of chromosome 20 [46, XX, del(14) (q32) del(20)(p11)]. Examination revealed that the infant had a peculiar face, a cleft and high palate, abnormal dentition, butterfly-like vertebral defects, finger anomalies, a simian line on the left hand, talipes equinovarus, deep plantar furrows, abnormally high values of alkali phosphatase and lactate dehydrogenase, mild anemia and psychomotor retardation. Comparing the present case with previously reported cases of single deletion of chromosome $14 q$ or chromosome $20 p$, the infant showed some of symptomatic and dysmorphic features of both deletions.

\section{34}

BECKWITH-HIEDEMANN SYNDROME-LIKE PHENOTYPE IN A GIRL WITH $14 \mathrm{q} 32 \rightarrow$ $14 \mathrm{qter}$ TRISOMY THAT WAS DETECTED WITH CHROMOSOME BAND-SPECIFIC PAINTING. Rumiko KaT0. Toshiro NAGAI (Ki yose Child. Hosp., Tokyo). Yoshimitsu FUKUSHIMA (Saitama Child. Med. Ctr., Saitama). Tohru 0HTA, Takaya TOHMA and Norio NIIKAWA (Nagasaki Univ. Sch. Med., Nagasaki).

The patient was complicated with following anomalies: macroglossia, hypertelorism, umbilical hernia, hepatomegaly and cardiomegaly. Growth and psychomotor retardation were noted. Chromosome analysis revealed an excess segment at the distal end of $17 \mathrm{p}$. We identified this part as $14 \mathrm{q} 32 \rightarrow 14$ ter with chromosome-band-specific painting developed previously. Her parents were phenotypically and karyotypically normal. Therefore, her karyotype was $46, X X,+d e r(17) t(14: 17)(q 32 ; p 13)$ de novo.

More than 20 cases of distal $14 \mathrm{q}$ trisomy have been reported. Main clinical findings include low birth weight, growth and psychomotor retardation, hypertelorism. protruding upper lip and micrognathia. But the patient had only retardation and hypertelorism. 0n the other hand, her major phenotype is frequently observed in Beckwith-Wiedemann syndrome. It remains to be seen whether a duplication of $14 \mathrm{q} 32 \rightarrow 14 \mathrm{qter}$ contributes to a Beckwith-wiedemann syndrome-like phenotype. 


\section{35}

A CASE OF MULTIPLE ANOMALY WITH PROXIMAL 15q MONOSOMY + PROXIMAL 21q TRISOMY. Shoji KAWASE, Hisayasu MORIOKA, Yasuhira ISHIWARI, Yasutaka MATSUO, Kou HASEGAWA, Akihiko KINUGASA,Tadashi SAWADA(Dept. Pediatrics,Kyoto Pref.Univ. Medicine, Kyoto), Jyoji INAZASA, Tatsuo ABE (Dept. Hygienics,Kyoto Pref.Univ.Medicine,Kyoto) and Kimiko SUGIURA(Kyoto Biseibutsu Kenkyusho, Kyoto)

多発奇形があり、15q近位部モノソミーと21q近位部トリソミーを伴った患児を経験し たので報告する。患児は36歳の父と23歳の母の第二子の女児として出生。この夫婦には 自然流産歴が 1 回ある。患児は在胎37遇、正常経䐦分婏で出生。出生時体重は3250g、 アプガースコア 1 分値 5 点、5 分值 7 点と新生児仮死があった。外表奇形として、両眼 離開、耳介低位、小耳介、扁平な鼻根、口蓋裂、短䅡、短い四肢があった。頭部では小 脳低形成、両側脳室拡張、心䑏では下行大動脈の拡張、腹部では脾腫、両侧水腎症があ り、レノグラムで腎機能低下を認めた。出生時より筋緊張の低下があり、経口哺乳はで きなっかた。呼吸状態等安定していたので、自宅にて、経鼻栄盖行ない体重増加があっ たが、生後 3 ケ月時、吐乳後の誤哭のため呼吸不全となり死亡となる。染色体検查で患 児の核型は、45,XX,15,t(14;15)(q11;p11),+der(21)t(15;21)(q15;q21)と同定され、15q近位部乇 ノソミーと21q近位部トリソミーが知られた。父の核型は、45,XY,t(14q;15q)で、均衡型 Robertson転座、母は、46,XX,t(15;21)(q15;q21)の縋列転座であったことから、患㫛は、 14/15転座染色体を父から、また、der(21)染色体を母から受け継いでいた。21q近位部卜リ ソミーであるが、いわゆる゙Down syndrome region"の重複を認めず、ダウン顔貌を呈して いない。15番染色体長腕の欠失部位が、Prader-Willi症候群やAngeiman症候群と関係すると 言われている部位であったが、生前それらを示唆するような所見は明らかではなっかた。

\section{36}

SATELLITED $X$ CHROMOSOME. Hiromi SAKAMOTO, Masafumi HANDA. Yoshie SUGAWARA, Hiroko MIMURA, Jun-ichi FURUYAMA (Dept. Clin. Genet., Hyogo Col. of Med. Hosp., and Dept. Genet. Hyogo Col. of Med., Nishinomiya)

The girl with neonatal thyrotoxicosis was born on 11 ,
September 1990 . She is the second child to 35-year-old
father and 33-year-old mother. She had been medicated to
keep her thyroid function normal. She did not develop the
lymphoedema. She have been short stature. Her chromosome was
analyzed for neglect Turner syndrome. Her parents have
normal karyotypes. Her karyotype is $46 . X$.Xpt. The extra
portion of her abnormal $X$ (Xps) chromosome was uncertain.
Her Xps chromosome showed NoR positive region at the distal
end of the short arm. The portion between Xp22.3 and Xater
may be normal. The normal X chromosome in 15 cells and the
Xps chromosome in 5 cells were late-replication pattern by $R$
banding using BrdU.
with $A$ satellited $X$ chromosome is vary rare. One is a woman
The mar(X) is the X chromosome bearing satellite on the
short arm which is similar to the Xps chromosome.


D 37

A WHOLE-BODY 46,XX/47,XY,+21 CHIMERA WITH GONADAL DYSGENESIS. Naoki HARADA, Kyohko ABE (Kyushu Med Sci., Nagasaki), Tomoko SAWAI, Tadashi MATSUMOTD, Masaaki YOSHIMOTO (Dept. Pediat., Nagasaki Univ. Sch. Med., Nagasaki), Norio NI IKAWA (Dept. Hum. Genet., Nagasaki Univ. Sch. Med., Nagasaki)

We report a whole-body chimera. The newborn had a small penis, bifid scrotum with testis-like masses, and hypospadias. Urethrography revealed a vagina-like cyst with the bladder. HCG loading test showed an elevation of serum testosterone level, indicating the existence of the testis. The SRY-sequence was amplified by PCR on the DNA from both leukocytes and skin fibroblasts. Chromosome analyses revealed a chi $46, \mathrm{XX} / 47, \mathrm{XY},+21$ karyotype. The latter cell-line in peripheral blood lymphocytes and fibroblasts took $6(2 \%)$ of 300 cells and $7(3.8 \%)$ of 185 cells observed. Chromosomal heteromorphism study on \#3 and \#4 and on the acrocentrics revealed different heteromorphic patterns between the two tissues, and that each of the three chromosomes 21 in trisomic cells showed a different pattern (abc pattern). From these findings, the following two mechanisms are plausible for the occurrence of the present whole-body chimerism: (1) Fusion of dizygotic twins, one twin with $46, \mathrm{XX}$ and the other with $47, \mathrm{XY},+21 ;$;2) Dispermy involving an ovum and its first polar body. Since the parents ' chromosomes were not available, we could not detect the true mechanism.

\section{38}

A RESPONSIBILITY SHARING SYSTEM OF PRENATAL DIAGNOSIS: A REPORT OF 1,277 CASES. Kyohko ABE, Naoki HARADA, Kazuo NODA (Kyushu Med. Sci., Nagasaki Labor., Nagasakí), Norio NIIKAWA (Dept. Hum. Genet., Nagasaki Univ. Sch. Med., Nagasaki)

We have adopted a system for country-wide prenatal diagnosis, where obstetricians, geneticists, and our laboratory share ethical and technical responsibility. Te report the results of 1,277 prenatal diagnoses for the past two years, consisting of 59 chorionic villus samples (CVS), 1,203 amniotic fluid samples (AFS) and 15 fetal blood samples (FBS). CVS was provided according to the indications: embryo/fetuses of carrier parents with structural chromosome abnormalities, those of mothers of over 40 years, and those at risk of genetic diseases to be DNA-diagnosed. Chromosome abnormalities were found in 18 (30.5\%) CVS, 2 of which showed discrepancy between CVS and AFS karyotypes, the higher rate being due to an accumulation of parents with structural aberrations. Chromosome abnormalities were observed in $6.3 \%$ of AFS that was higher than the previously reported rates, reflecting more fetuses of over 25 weeks with malformations in our series. PseudomosaicisI was observed in 4 AFS. Fifteen FBS were all provided froll severely malformed fetuses, $7(46.7 \%)$ of which had abnormal karyotypes. Of 45 structural aberrations found in CVS/AS, 3 were complex ones and 7 needed further high-resolution analyses. 
D 39

CHROMOSOME ANALYSIS IN 72 BRAIN TUMORS WITH SPECIAL ATTENTION TO THE LOSS OF SEX CHROMOSOME. KiyOmi YAMADA, Midoriko KASAMA (Div. Genetics, Clin Res Inst), Nobutada SHINOURA, and Tatuya KoNDO (Brain Surgery, Nat Med Cent Hosp, Tokyo)

Chromosome analysis was done in cells from primary cultures of 72 brain tumors. Clonal cells with autosomal abnormalities were observed in 41 tumors. Of 24 meningiomas, 21 had monosomy 22 as a specific abnormality. Trisomy 3, 7, and structural abnormalities involving chromosome 22 were observed frequently in 29 gliomas. Sex chromosome aneuploidy due to the loss of a $Y$ (in $41 \%$ of males) or a X (in 26\% of females) was observed regardless of cells with or without autosomal abnormalities. It was observed in 25 tumors in frequency of $10 \%$ to $100 \%$ (average 54\%) of analyzed cells and was common in meningiomas and gliomas. From analysis in histologically non-malignant tissue (1 case), metastatic tumors ( 3 cases), and long-term cultures of the present materials $(7$ cases), the loss of sex chromosomes was considered to have an advantage for cell growth, but not to have relation to initiation of carcinogenesis in the brain tissue. We have inferred that $45, x$ cells are more abundant in normal brain tissue than observed in other body tissues.

\section{40}

TWO CASES OF COSTELLO SYNDROME. Reiko YOSHIDA, Yukio FUKUYAMA (Dept. Pediatr. Tokyo Women's Medical College, Tokyo), Yoshimitsu FUKUSHIMA , Hirofumi OHASHI (Division of Medical Genetics Saitama Children's Medical Center, Saitama) and Masako ASOH (Johoku Branch Hospital Tokyo Metropolitan Kita Medical Rehabilitation Center for the Handicapped, Tokyo )

In 1977 Costello reported 2 children with characteristic face, loose skin of the hands and feet, postnatal growth failure, mental retardation, and nasal papillomata. We present two unrelated cases ( 6 years old gir1 and 3 years old boy ) with Costello syndrome who haven't nasal papillomata. Both patients are the products of non-consanguineous healthy parents. They were fed by tube in their infancy. Both cases have relative or absolute macrocephaly at birth, curly hair, large ear lobe, epicanthal folds, low nasal bridge, thick lips, short and wide nose, short neck, barrel chest, redundant skin on hands and feet, hyperextensibility of finger joints, thin nails, dark skin, tight Achilles tendon, and pes equinus. A11 of these features are consistent with the description by Costello except for the absence of nasal papillomata. A brief review of literature about Costello syndrome and the mental retardation syndrome with facio-cutaneous-skeletal involvement (Borochowitz 1992 ) which has much similarities with Costello syndrome is presented. 
D 41

\author{
THE COSTELLO SYNDROME: REPORT OF AN ADDITIONAL CASE AND \\ REVIEW OF LITERATURE. I Ikuko KONDO(Dept. of Hygiene, Ehime \\ Univ.Ehime), Kohichro TAMANAHA, Kaoru ASHIMINE (Dept. of \\ Pediatr., Okinawa Prefect. Chyubu Hospital, Okinawa)
}

We examined a 5 yea-old girl with the Costello syndrome. When findings from our patients and those from other patients in the literature were combined, the following abnormalities were observed: mental retardation, characteristic face with curly hair, hypertelorism, depressed nasal bridge, nasal papillomata, thick lips and large ear lobes, and dark loose skin of hands and feet. Male and female patients were equally affected. Two reported patients were born to related parents and their mothers had not any drugs and infections during pregnancy. These data suggested that the Costello syndrome is a genetic disorder of which mode of inheritance might be autosomal recessive.

D 42

A CASE OF MULTIPLE EPIPHYSEAL DYSPLASIA. Mitsushiro KIDA (Fac.of Pediat. Teikyo University School of Medicine, Tokyo) Katsuya AIZU and Shinya ENOMOTO(Kumagaya Consumer's Co-operative Hospital, Saitama Pre.)

A 5-year old male child counsulted us with chief complaints of slightly curved forearms and a somewhat odd way of running. No particular abnormalitieswere found in joint movements throughout the body. However the patient showed deformation of the elbow joints and could not sit upright due to an inability to rest on the heels in a sitting position. The patient mesured $105.8 \mathrm{~cm}(-0.6 \mathrm{SD})$ in stature. with a head circumference of $51.0 \mathrm{~cm}$ both forarms measuring $13 \mathrm{~cm}$. The right femur measured $28 \mathrm{~cm}$, left $29 \mathrm{~cm}$; right leg mesured $43.4 \mathrm{~cm}$, left $43.0 \mathrm{~cm}$; each showing a minor difference between the right and left.X-ray examination reveals hypertrophy of the elbow joints and knee joints and slightly irregular development of the epiphysis, leading us to diagnose the present case as multiple epiphyseal dysplasia, not of the minor epiphyseal nucleus type described first by Fairbank in 1935, but of the epiphyseal type first reported by Ribbing in 1937 . Acoording to the literature, this disease is observed relatively frequently.This disease is a genetic disease of autosomal dominat that is readily overlooked, despite its relatively frequent occurence, because of striking variations in the manifestation of its phenotype. This disease may possibly induce osteoarthritis during the adult period, requiring monitoring of the entire course of the disease. 
D 43

PHENOTYPIC CHARACTERISTICS OF BRACHMANN-DE LANGE SYNDROME EVALUATION USING METACARPO-PHALANGEAL PATTERN PROFILES. Takeyasu IGARASHI' ${ }^{\prime}$, Tomoko HASEGAWA ${ }^{1}$, Katsuhiko AOKI ${ }^{2}$, Akio ASAKA ${ }^{3}$ ( ${ }^{1}$ Div. Clin. Genet., Shizuoka Children's Hospital., ${ }^{2}$ Div. Radiology, Shizuoka Children's Hospital., ${ }^{3}$ Dept. Health Sci., Yamanashi Med. Coll.)

\footnotetext{
Brachmann-de Lange syndrome (BDLS) is a malformation syndrome of uncertain cause characterized by growth deficiency, psychomotor retardation, characteristic facial features, and limb and other anomalies, with a wide range of variability in these clinical symptoms. We evaluated 12 BDLS patients (age: 2 yr4 mo - 13 yr8 mo, M:4,F:8) with regard to clinical manifestations, psychomotor development, and metacarpo-phalangeal pattern profiles (MCPP). We classified the typical BDLS patients into two groups according to head circumference (OFC) at birth (boundary line: -2 S.D.). The third group consisted of atypical BDLS patients. Our data suggested that the smaller ofC group showed a preponderance of females, and showed more severe malformations and psychomotor retardation. MCPP revealed an abnormal pattern in almost all cases, especially a short first metacarpal bone and a short second middle phalangeal bone. There was almost no difference in this tendency between the two typical BDLs group. The atypical group showed no distinct pattern profile. We consider that MCPP of BDLS patients may be diagnostically useful, especially in mild and difficult cases.
}

D 44

A CASE REPORT OF ATYPICAL NORRIE DISEASE. Nobuhiko OKAMOTO, Hideaki CHIYO Michiko KOBAYASHI, Kazuko WADA, MasanoriFUJIMURAKEn-ichi SATOMURA YOShikazU HATSUKAWA (Osaka Med. Center and Res. Inst. for Maternal and Child Health) and Hiromi SAKAMOTO (Dept. of Genet., Hyogo College of Med.)

Norrie disease is an $\mathrm{X}$-linked recessively inherited disorder. In the "classic form", this disorder is characterised by early vascular proliferation in both retinas, progressing to phthisis bulbi. About half the patients manifest mental retardation, often with developmental regression or psychotic features. Atypical patients with submicroscopic $X$ chromosomal deletions and MAO deficiency has been described with features growth disturbance, microcephaly, sunken eyes, hypotelorism, thin upper lip, large ears. This clinical syndrome represents a " contiguous gene syndrome" . We describe here an atypical Norrie disease patient with left accessory thumb, polysyndactyly of left 2nd toe and chronic renal failure. The patient was the second child born to non-consanguineous parents. His birth weght was $1990 \mathrm{~g}$ at term. He had typical ocular manifestations with digital anomalies and atrophic kidnies. He is now 1 year old and physical growth and mental development are severely retarded. His karyotype was $46, X Y$ on high resolution G-band. 
D 45

\section{A FAMILY OF OPITZ-BBB SYNDROME WITH A MEMBER OF APPERENT \\ G SYNDROME. Hide-aki CHIYO, N. OKAMOTO, M.KOBAYASHI,} J.NISHIO, R.KITAMURA, M.FUJIMURA (Osaka Medical Center and Research institute for Matemal and Child Health , Osaka), N.SHIMIZU (Yodogawa Christian's Hospital, Osaka)

1 year-old boy was diagnosed as Opitz-G syndrome because of severe postnatal respiratory distress in addition to hypertelorismus, cleft lip/palate, hypospadia and anal atresia. His elder brother was also found to have the same clinical features but for the episode of respiratory distress, so he was diagnosed Opitz-BBB syndrome. The mother had hypertelorismus and widow's peak which are the signs of Opitz-BBB syndrome. The overlapping of clinical features between BBB syndrome and $\mathrm{G}$-syndrome was reported so further investigations would be needed to establish the clinical entity of G-syndrome.

\section{46}

The heritability of body weight, height and Kaup's Index from birth to 11 years.---- By use of 'LISREL7'. Shyuichi OOKI, Toru KINOSHITA. Akio ASAKA (Dept. Health Sci.,Yamanashi Medical University, Yamanashi)

The present study was focused on an application of the muximumlikelihood model-fitting analysis for twin data. Subjects were $424 \mathrm{MZ}$ and 112 same-sexed DZ. Heritability of body weight, height and Kaup's Index from birth to 11 years was estimated by use of statistical program package 'LISREL7'. In this study additive gene factor and random environmental factor were adopted as latent variables. The results were as follows; 1. Model-fitting was the worst at birth, suggesting that other latent variables played an important part in this period. 2. Genetic influence became rapidly apparent from birth to 3 years of age and then became stable. So the gene action of early infant period should be analyzed in more detail. 3. After 3 years, height, weight, Kaup's Index were genetically controlled in this order. It was concluded that this method is a new approach for genetic analysis, and effective especially for the analysis of genetic characters under polygenic control. 
D 47

\begin{abstract}
PERSONALITY CHARACTERISTICS SEEN IN CENTENARIAN TWIN SISTERS .

Takamasa SAITO(Dept. Mental Health, Fac. Med., Univ. Tokyo, Tokyo), Akio ASAKA (Dept. Health Sciences, Yamanashi Medical Univ., Yamanashi) and Ichiro MATSUI(Dept. Child Ecology, Nat1. Children Med. Res. Ctr., Tokyo)
\end{abstract}

This is a report on a case of centenarian identical twin sisters ( $K$ and $G$ ). We examined their personality traits through data obtained by conducting interviews and psychological tests: their families were also interviewed. Intellectually, they are almost the same. But, on immediate memory, $K$ is superior to $G$, whereas $G$ is superior to $K$ on verbal fluency. There are some differences in their attitudes toward tasks: $K$ gives up quickly compared to $G$.

In personality $K$ and $G$ are spirited, cheerful, hard workers, stubborn, impatient and irascible. Previous studies report that androgyny is psychologically most adaptive in old age. $\mathrm{K}$ and $\mathrm{G}$ also demonstrate androgyny psychologically. In addition, we consider that friendly competition between $K$ and $G$ helps them sustain their daily activities.

\title{
D 48
}

GENEVIEW: A HUMAN GENOME MAPPING LIBRARY SYSTEM ON THE WORKSTATION Shinsei MINOSHIMA ${ }^{1}$, Hiroshi DOHI ${ }^{2}$, Mitsuru ISHIZUKA ${ }^{2}$ and Nobuyoshi $\underline{\text { SHIMIZU }}^{1} \frac{{ }^{1} \text { Department of Molecular Biology, Keio University School of }}{2}$ Medicine, ${ }^{2}$ Institute of Industrial Science, University of Tokyo)

Access to the human gene map information is indispensable to facilitate human genome research. Mapping data has been compiled at the annual Human Gene Mapping Workshop and integrated into the computerized Genome Data Base (GDB) at Johns Hopkins University (JHU). The GDB is one of the most important database for storage of genome mapping information. Recently, Japan official node of GDB was established at Japan Information Center for Science and Technology (JICST) and environment set-up for the general user is in progress.

In order for effective use of the GDB data, we have developed a stand-alone library system, GeneView, which operates on a workstation equipped with $\mathrm{X}$ window. Map data $(\sim 10,000$ entries) and reference data $(\sim 20,000)$ were manually input. GeneView offers numerous features: (1) fast search operation; (2) visualization of map; (3) excellent manmachine interface; (4) multi-languages for display layout and input/output of search (Japanese and English are available at present). The current version of GeneView is now installed on a Sun SPARC station 2 at Keio University. 